\title{
PLACING THE CARDSTON TEMPLE IN EARLY MORMON TEMPLE ARCHITECTURAL HISTORY
}

\author{
By \\ Amanda Buessecker \\ A Thesis Presented in Partial Fulfillment of the Requirements for the \\ Master of Arts Degree in Art History \\ Carleton University \\ May 2020
}

Supervisor: Peter Coffman, Ph.D.

Carleton University 


\begin{abstract}
:
The Card ston temple of the Church of Jesus Christ of Latter-day Saints represents a drastic shift in temple architecture of the early Mormon faith. The modern granite structure was designed not to show a mere difference of aesthetic taste, but as an embodiment of the evolving relationship between the Mormon pioneers and the American government. Earlier temples, erected in the nineteenth century throughout the valleys of Utah, were constructed by Mormon pioneers at a time when the religious group desired to separate themselves from the United States physically, politically, and architecturally. When the temple was built in Cardston, Alberta (1913-1923), it was a radical departure from its medievalist predecessors in Utah. The selected proposal was a modern Prairie-school style building, a manifestation of Utah's recent interest in integrating into American society shortly after being admitted to the Union as a state in 1896.
\end{abstract}




\section{Contents}

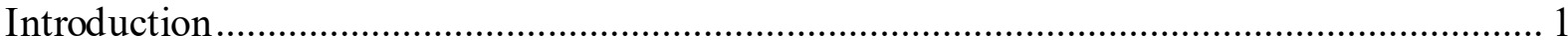

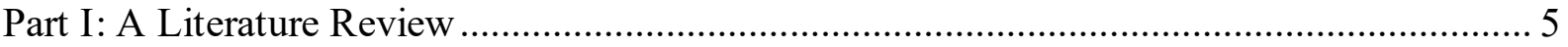

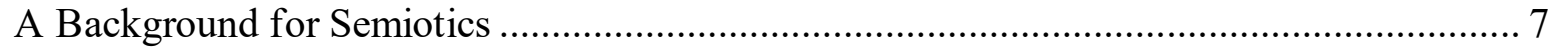

Creating Meaning in the Christian Church................................................................. 10

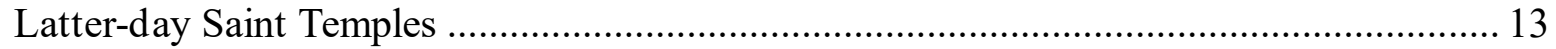

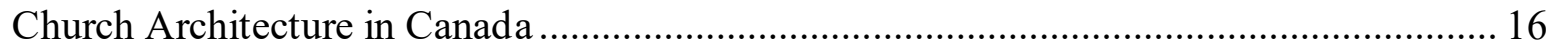

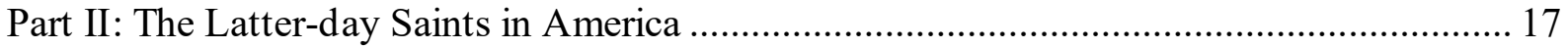

$19^{\text {th }}$ Century Mormons and the American Government .................................................. 23

Nationalistic Ideology of the Pioneer Temples ............................................................. 26

Transition "From Satyr to Saint:" Reintegration into American Society........................... 29

The Function of the Temple as Sacred Space ............................................................. 33

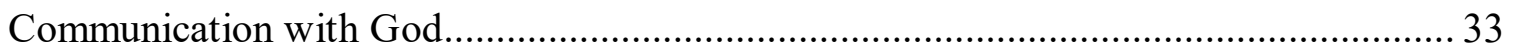

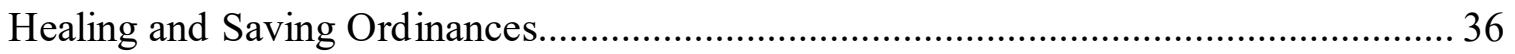

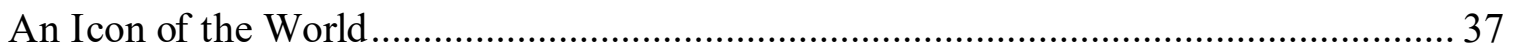

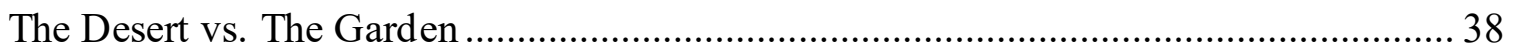

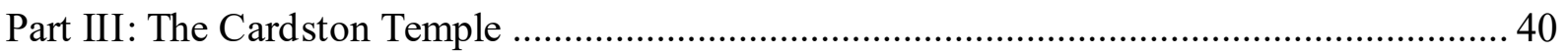

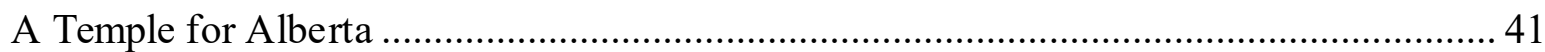

Moving to Modernity: The Cardston Temple and Frank Lloyd Wright's Unity Temple .... 45

Costs of the Card ston Temple ................................................................................. 52

Architectural Creation of Sacred Space in the Early Temples ........................................ 57

The Canadian Temple as a Symbol of Mormon Reintegration into the United States ........ 62

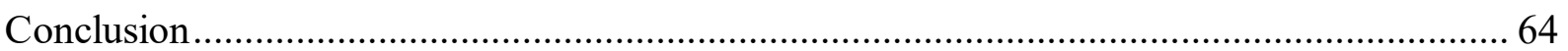

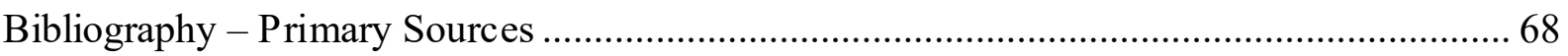

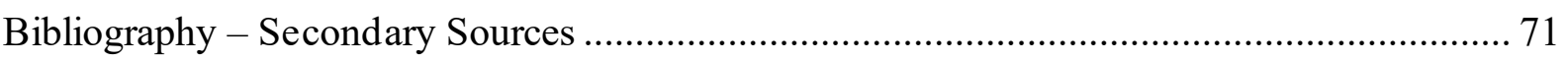

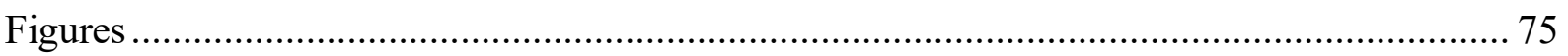




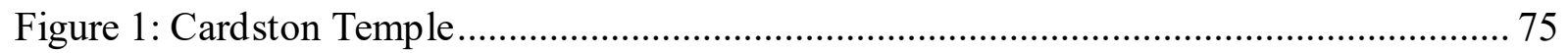

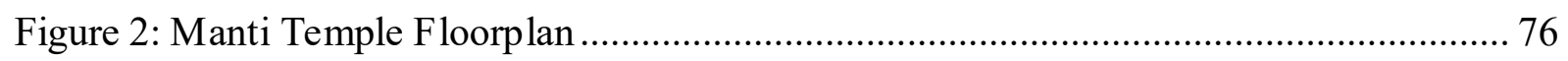

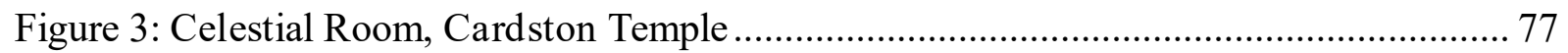



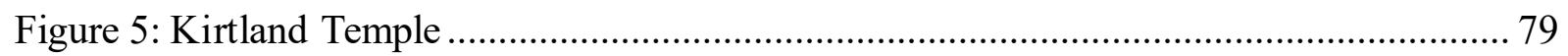

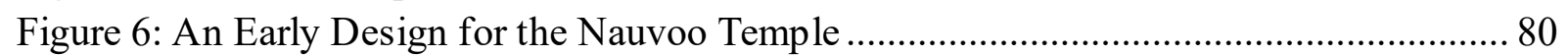

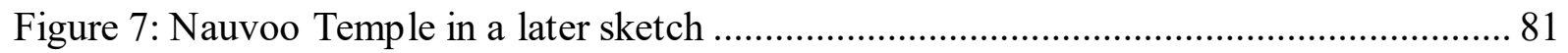

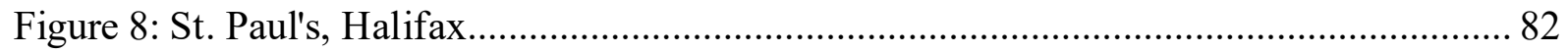

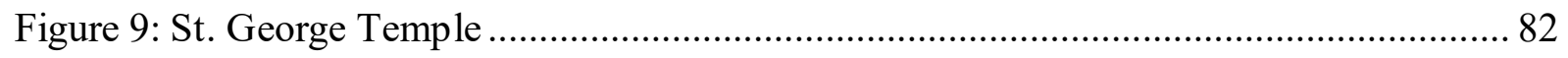

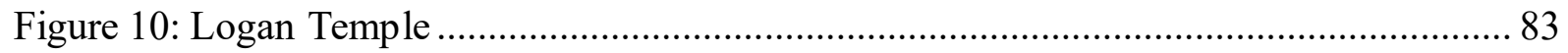

Figure 11: Manti Temple

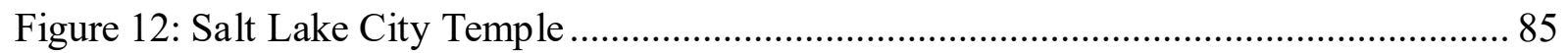

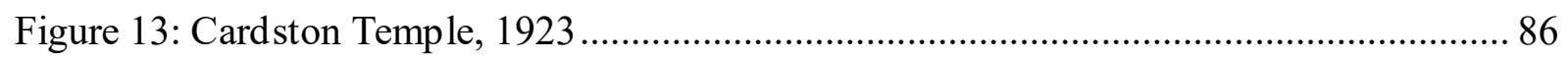

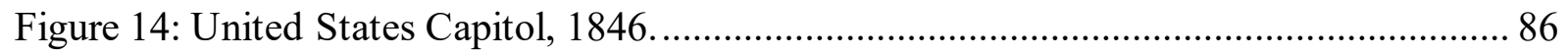

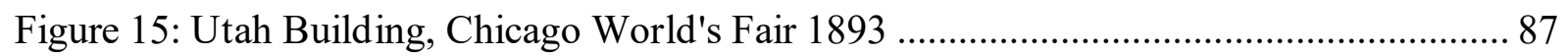

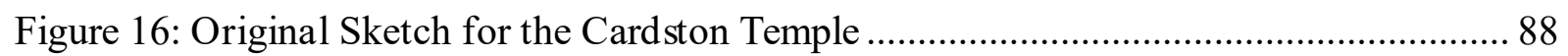

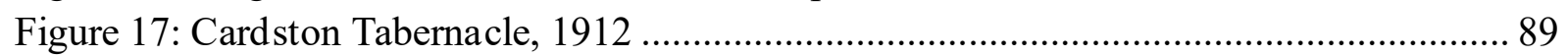

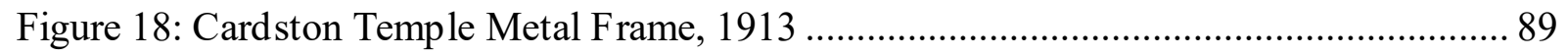

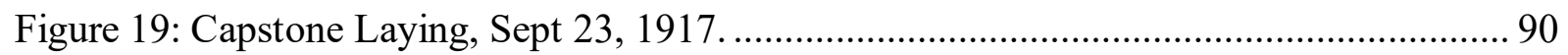

Figure 20: Salt Lake First Ward, Designed by Pope \& Burton, 1910..................................... 91

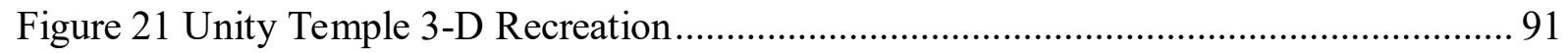

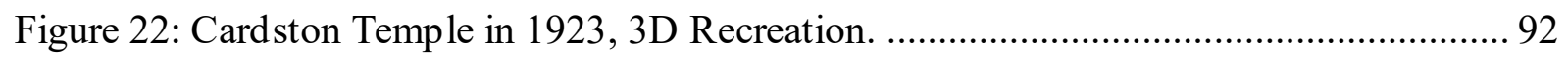

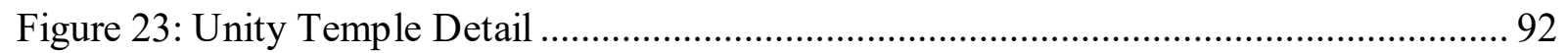



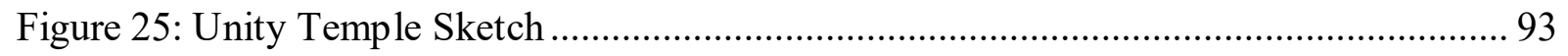

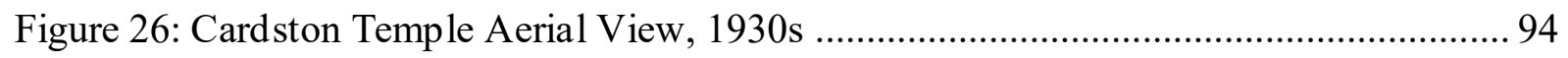

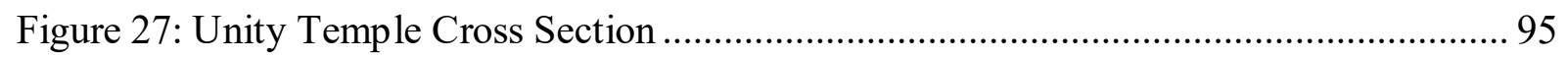

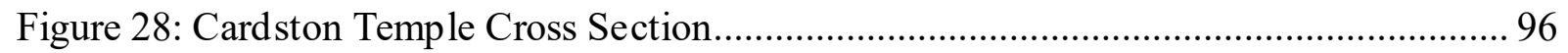

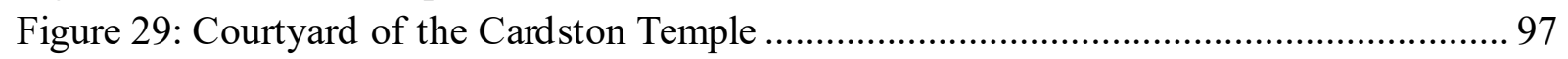

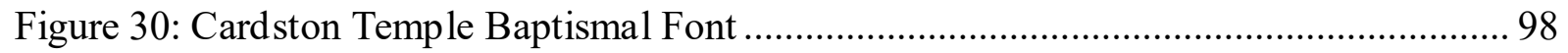

Figure 31: Cardston Temple after the 1960's Renovation, 3D Recreation .............................. 99

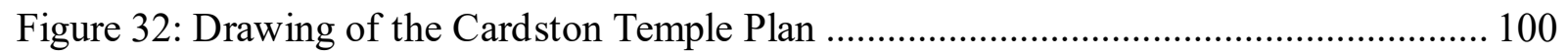

Figure 33: Section of the Cardston Temple Garden Room Mural ...................................... 101

Figure 34: Section of the Cardston Temple World Room Mural .......................................... 102

Figure 35: Pope \& Burton Proposal for the Mesa Temple.................................................... 103

Figure 36: Young and Hansen Winning Design for the Mesa Temple ................................... 103

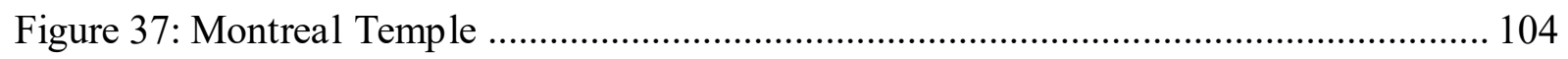

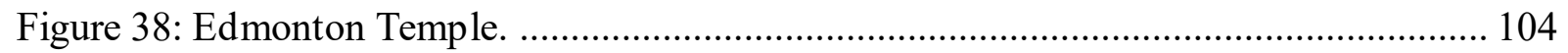




\section{Introduction}

Temples of the Church of Jesus Christ of Latter-day Saints have long been a distinguishing factor of the faith's presence in a region. Often confused with meetinghouses used for Sunday worship and found more frequently throughout the world, the temple is rather a gathering place for the faithful where they participate in sacred religious rites that differ from Sunday services. Members of the faith, often referred to as Latter-day Saints or Mormons, have historically travelled long distances and made great sacrifices to attend the temple a mere handful of times throughout their life, though today the presence of a Latter-day Saint temple in more than one hundred cities throughout the world means that church members may choose to attend as frequently as their schedules permit. Since the establishment of the Church of Jesus Christ of Latter-day Saints in 1830, temple building has been among the highest of priorities. From the first temple in Kirtland, Ohio (1836), to the recent dedication of a temple in Sapporo, Japan (2016), the temple has become not only a cultural symbol of the Latter-day Saint faith, but a living metaphor for the religion's members in understanding their eternal progression.

In discussing the theological and cultural importance of their temple experience, Latterday Saints have traditionally not placed emphasis on the temple structure itself, but on the rituals that are performed therein. The ritual experience is only discussed vaguely, however, as particular details about the temple ceremony are generally not discussed outside of the temple, thus creating a certain aura of secrecy regarding temple worship. ${ }^{1}$ The Church's position is that the temple is "sacred, not secret" and that while all individuals throughout the world are invited to prepare for and become worthy of the ord inances of the temple, the details of temple

\footnotetext{
${ }^{1}$ Boyd K. Packer, Preparing to Enter the Holy Temple (Salt Lake City: The Church of Jesus Christ of Latter-day Saints, 2002), 21-23.
} 
experiences are reserved for the faithful. ${ }^{2}$ Despite this claim, scholar Bradley Kramer argued in his University of Michigan doctoral dissertation that the temple's sacredness in fact arose from the concept that the ritual ceremonies contained ideas to be kept secret, and that the sacred ideology of the temple was a "collaboratively and socially enacted value which depends on secrecy and confidentiality."3 However, rather than mere reliance upon a socially enacted value, I assert that early temple architecture is critical in making the temple a sacred space for Latterday Saints; the sanctity of the temple is not only enhanced by, but dictated by, the architectural and iconographical design that is supplemental to, but separate from, the ord inances that occur therein.

Part I of this thesis discusses the analytical methods through which religious architecture provides meaning, beginning with an overview of Roland Barthes' introduction to semiotics and expanding upon Umberto Eco's application of Barthes to architecture. Eco explains that most architecture functions not to communicate but to meet a physical need, but that perhaps a physical function can indeed be connected to communication. ${ }^{4}$ A church, for example, can do more than merely house a congregation, for its architecture can dually serve as a liturgical tool; the Gothic cathedral is used as an example. Finally, a brief overview of the existing literature both on Latter-day Saint temples and on Christian church architecture in Canada is included.

\footnotetext{
2 David O. McKay, “The Purpose of Temples,” Ensign, Jan. 1972,38. Ordinances in the Church are the sacred rites, called in the Catholic tradition "sa craments," that a re essential for eternal salvation. In the Church of Jesus Christ of Latter-day Saints, ordinances refer to baptism, the eucharistic ceremony referred to merely as "the sacrament," and the temple rituals of the endowment and the sealing. The endowment is a ceremony in the temple in which the Latter-day Sa int makes covenants, or promises, to God, and the sea ling ceremony is a Latter-day Saint marriage that is deemed valid for eternity rather than until death. All ordinances have standardized wording and approved, authorized translations and as a result are the exact same when administered anywhere in the world.

${ }^{3}$ Bradley H. Kramer, "Keeping the Sacred: Structured Silence in the Enactment of Priesthood Authority, Gendered Worship, and SacramentalKinship in Mormonism," PhD. diss., (University of Michigan, 2014 ), 20.

${ }^{4}$ Umberto Eco, "Function and Sign: The Semiotics of Architecture," in Rethinking Architecture: A reader in cultural theory, ed. Neil Leach (London: Routledge, 1997), 174.
} 
Part II investigates how political and social factors impacted nineteenth-century architecture for temples of the Church of Jesus Christ of Latter-day Saints. The changing relationship between the Church and the American government is documented as it pertains to Latter-day Saint architecture. This section also describes how the early Latter-day Saint temples, built between 1877 and 1956, embody characteristics of sacred space described in the Encyclopedia of Religion by Joel Brereton. These temples relied upon their architecture to promote among temple visitors the ideology of the temple as a sacred space and to further legitimize the church's claims of divine leadership. In the latter half of the twentieth century, however, temple architecture changed dramatically as temples were built more frequently and on a significantly smaller scale.

This research has been driven by the lack of scholarship on the early temples as one cohesive group. While a larger study could analyze the political circumstances that contributed to the building of each of the early temples, this thesis specifically outlines the transition between the Pioneer temples and the temple in Cardston, Alberta, providing context for why and how the American religion came to build a monumental, modernist building in the Canadian province.

Part III of this thesis explores the history of the Cardston temple — designed by Hyrum Pope and Harold Burton in the early twentieth century—and the architectural, political, and social influences in its construction (see fig. 1). In contrast to the nineteenth-century temples built in Utah, with resplendent medieval designs, the Cardston temple was built in a much more modern Prairie school style and was heavily influenced by Frank Lloyd Wright's Unity Temple. Despite its location on Canadian soil, I will argue that the Cardston temple, breaking from precedent of the established Latter-day Saint pioneer temples, represents the Church's embracing of American values following Utah's admission to the American union as a state. 
It should be noted that I am an active and faithful member of the Church of Jesus Christ of Latter-day Saints. This association provides me with a deep understanding of cultural norms and expectations of the Latter-day Saint tradition, beliefs, and values. As a member of the Church, I am familiar with the temple ceremonies, having personally participated in temple practices in each of the Pioneer temples as well as the Cardston temple. These ceremonies are held sacred by adherents to the faith, and my intention is always to discuss temple ordinances in enough detail to provoke academic thought and yet maintain the reverence for the temple that is expected of Church members. Additionally, the Church released in 2019 a new style guide that discourages the use of the term 'Mormon' in describing the Church or its members. I have retained the use of the word Mormon only inasmuch as it describes the historic religious group in the nineteenth and early twentieth centuries, on which my research is focused. The term describes the predominantly white European and American members of the Church of Jesus Christ of Latter-day Saints that established a new home in what was once Mexico territory (and which became almost immediately Utah Territory of the United States) and their descendants who would establish homes in western Canada. Many of these Mormon pioneers referred to themselves and their religious group simply as "Saints." In any description of practices, beliefs, or people that continue into the contemporary world, I have made my best effort to support the use of the term "Latter-day Saint," which is the appropriate way to describe one who is today a member of a very global and diverse church. The reader should be aware, however, that the terms can be used interchangeably in this thesis. Additionally, the full name of the Church of Jesus Christ of Latter-day Saints will frequently be shortened to "the Church." My views are in no way endorsed by the Church and my id eas do not represent official Church doctrines or teachings. 
Researching Latter-day Saint temples is limited by specific barriers. Church-held archives that pertain to temples, including floorplans, original designs, associated costs both in build ing and maintenance, past changes made during renovations, interior images, and any analysis of artwork or structural symbolism are held centrally at the Church's headquarters in Salt Lake City, Utah. Archival files relevant to all Church-operated temples are closed to research for both members and non-members of the Church. The files are not available for academic or personal study and are accessible only by Church employees. While the Church does publish a limited selection of photographs of temple interiors, the photographs do not indicate any sense of location within the temple or how the rooms are connected. A church employee was adamant that temple floor plans, even historic ones for temples that have since undergone numerous renovations, are guarded for security purposes. Many images used in this thesis have been collected by previous scholars at a time when access to Church archival material was less limited, and attempts to extract new images, floorplans, or temple information from Church files have been unfruitful.

\section{Part I: A Literature Review}

To question the meaning of religious architecture is to continue a tradition that Erwin Panofsky proposed was begun with the birth of scholasticism by eleventh century philosophers Lanfranc and Anselm of Bec in their "heroic attempt to settle the conflict between reason and faith." At nearly the same moment and within the same environment as the emergence of scholastic thought about religion in Paris, critical analysis of the meaning of architecture was born at Abbot Suger's Basilica of St. Denis. The desire of the scholastic movement to clarify and

\footnotetext{
${ }^{5}$ Erwin Panofsky, Gothic Architecture and Scholasticism (New York: World Publishing, 1951), 4.
} 
explain through logic and reason was applied to the High Gothic cathedral as the building, through architecture "sought to embody the whole of Christian knowledge." ${ }^{\prime}$ Architecture became a liturgical tool, and the church became a place not only of contemplation but a space to be contemplated.

"Buildings are as useful to our minds as they are to our bodies," said John Onians in the introduction of his text Bearers of Meaning — and churches epitomize this thought. ${ }^{7}$ The verticality of many gothic spaces call to mind the height of the heavens; the elevation of an altar at the end of a long nave alludes to the long distance that separates the worshipper from God. Complex symbolism within church spaces recall the complex mysteries worked by an allpowerful creator and reminds those worshipping in the space that knowing God requires seeking to understand His ways. Yet Christian churches are unique because, to some extent, cultural context within one religious tradition is similar throughout the world and variation is found more frequently from denomination to denomination. Certainly, this is the case for the interpretation of signs and codes in the Church of Jesus Christ of Latter-day Saints, where strong centralization in Salt Lake City, Utah, ensures that church materials, curriculums, and experiences are nearly identical worldwide. To study the impact of cultural context upon visual interpretations, however, it is crucial to understand the origins of contextual studies upon iconography, and the option for architectural analysis as an extension of semioticians Roland Barthes and Umberto Eco.

${ }^{6}$ Ibid, 44.

${ }^{7}$ John Onians, Bearers of Meaning (Princeton: Princeton University Press, 1988), 3. 


\section{A Background for Semiotics}

Roland Barthes' "The Rhetoric of the Image" provides a foundational model for the analysis of signs and codes in which a strong understanding of cultural contexts is required. Using a Panzani print advertisement for his example, Barthes differentiates between non-coded, denoted meanings, and coded, connoted meanings. ${ }^{8}$ Non-coded images, such as a photographic image, correlate a literal re-presentation of the object it is meant to signify—or a denoted meaning — such as an image of a tree representing a tree. ${ }^{9}$ Coded associations, however, are connected to cultural and symbolic meanings. ${ }^{10}$ bell hooks, for example, describes the coded iconic message in her memoir Bone Black: Memories of Girlhood when she discusses the connotations associated with a different dresses: the wearer of a red dress is sultry and sensuous, while a pink dress of a slightly different hue connotes a wearer who is perceived as sweet and innocent. ${ }^{11}$ Yet according to Barthes, some visual signs, rather than being images, are linguistic though still contain both literal and symbolic meanings. ${ }^{12}$ An advertisement might use a noncoded message by placing the company's name, Panzani, on the page. Only the ability to read and a knowledge of the language in which it is written is required to find the meaning of the letters. ${ }^{13}$ Yet Panzani also serves to advertise the "Italianicity" of the food products in the photograph, a fact that requires cultural knowledge. ${ }^{14}$ As another example, the inscription on a church building might merely state the name of the religion or congregation with which that building is associated, though an inscription written in Latin might suggest the ecclesiastical

\footnotetext{
${ }^{8}$ Roland Barthes, "The Rhetoric of the Image" (1964), 154. Available online at https://faculty.georgetown.edu/irvinem/theory/Barthes-Rhetoric-of-the-image-ex.pdf.

${ }^{9} \mathrm{Ibid}, 158$.

${ }^{10}$ Ibid, 160.

${ }^{11}$ Anne D'Alleva, Methods \& Theories of Art History, $2^{\text {nd }}$ ed. (London: Laurence King Publishing, 2014), 26.

12 Barthes, 153.

${ }^{13}$ Ibid.

${ }^{14}$ Ibid.
} 
nature of the building's purpose, where a message written in the vernacular might imply that communicating a message to the general public is an overarching priority.

Barthes does identify the difficulty of interpretation when there is an inherent variety of connoted meanings based on the diverse contextual differences of the viewers. Practical, national, cultural and aesthetic variations of a sign may exist, though he remains optimistic that this co-existing poses no threat to semiotic interpretation when the proper cultural context is assumed. ${ }^{15}$ Acknowled ging that a sign may be associated with one connotation in one culture does not invalidate the fact that the same sign may mean something else in a different social setting. Many Christians, for example, may choose to wear a cross pendant as a symbol of their Christian faith and as a reminder "to themselves of their commitment to one who laid down his life in love for friends and enemies." 16 Members of the Church of Jesus Christ of Latter-day Saints, however, avoid the use of the cross as a sacred symbol; for a Latter-day Saint to wear a cross may be viewed by those within the faith's tradition as rebellious or disrespectful, and is generally frowned upon. ${ }^{17}$

The gap between Barthes' Saussurean approach to semiotics and the study of architecture was bridged by twentieth-century semiotician Umberto Eco. In his Semiotics of Architecture, Eco discusses the complex relationship between architecture that exits to fulfill a function and architecture that incorporates variable stylistic tastes to connote cultural meanings and values. ${ }^{18}$ Building on Barthes' idea of denoted and connoted meanings, his explorative treatise alternates

\footnotetext{
15 Barthes, "The Rhetoric of the Image," 160.

${ }^{16}$ William E. Phipps, Supernaturalism in Christianity: Its Growth and Cure (Macon: Mercer University Press, 2008), 85

17 Joseph Fielding Smith, Answers to Gospel Questions, v. 4 (Salt Lake City, UT: Deseret Book Company, 1963), 17-18. President Smith explained that wearing the cross by a Latter-day Saint would be done in "very poor taste." Bruce R. McConkie described the cross as a symbol of "apostate” Christianity. See Bruce R. McConkie, Mormon Doctrine (Salt Lake City, UT: Bookcraft, Inc., 1958), 160.

18 Umberto Eco, "Function and Sign: The Semiotics of Architecture," in Rethinking Architecture: A reader in cultural theory, ed. Neil Leach (London: Routledge, 1997), 174.
} 
between the thesis: that architecture exists to function - and between his own counterattacks that argue for a connoted message as a function of the structure. Eco, like Barthes, maintains that meaning can only be determined by those who understand the codes involved in production. ${ }^{19}$ Using the example of a chair, he proposes that the primary function, or the denoted function, is to be sat upon. Just as Barthes explains that an image of a tree denotes an actual, physical tree, Eco's idea of denoted meaning is that an object clearly demonstrates its purpose. Yet the secondary, connoted function can clarify who or what may sit: a throne, for example, connotes that not anybody may sit, and in fact the sitter would likely sit stiffly, with a sceptre and a crown, thereby not sitting well at all respective to the utilitarian, denoted purpose of the chair. ${ }^{20}$ The throne connotes that the sitter is one of utmost importance and status in a community, though these ideas are formed through exposure to culture and shape what viewers see and how they find meaning in their surroundings.

Eco also exposes a catch-22 when applying semiotic analyses to architecture. While insisting that form both makes the function possible and denotes the function "clearly enough to make it practicable as well as desirable," he relies on the architect to have a clear understanding of the culture so as to be able to clearly express the denoted functions. ${ }^{21}$ However, an architect cannot make new forms functional "without the support of existing processes of codification." 22 How, then, can an architect introduce architectural elements that can both denote and connote new concepts to a population? What leads to the shift between new architecture and architecture that bears meaning?

\footnotetext{
19 Eco, 178.

20 Ibid, 179.

21 Ibid, 178.

22 Ibid.
} 


\section{Creating Meaning in the Christian Church}

That the Christian church was meant to be symbolic is without question - in the introductory essay of Neale and Webb's translation of Guillaume Durand's The Symbolism of Churches and Church Ornament, an analysis is drawn between the Jewish temple and the Christian basilica, stemming from Christ's teaching in John 10: "I am the door." The biblical book of Hebrews expands upon Christ's role as the Jewish temple's symbolic new veil. One would have to enter directly through Christ to reach the presence of the Father. The whole Christian basilica thus becomes a symbol of the Holy of Holies, the location of God. One enters through the door or narthex of the basilica, which Christ likened to himself, and the author of Hebrews likened to the veil of Jerusalem's temple. When a Christian entered the door to a Christian church, they were symbolically entering the Holy of Holies, a space that had, for the Jews, been only accessible to the High Priest on the Day of Atonement. ${ }^{23}$ The ability to symbolically enter this sacred space is referred to in the common crucifix-plan of these churches, reminding the visitor that it is only through the death of Jesus Christ, rather than a sacrificial goat as was the Jewish tradition, that enabled the general population to approach the throne of God.

The Gothic cathedral reached a pinnacle of using subtle signs to connote the presence of God. Some structures, such as Beauvais Cathedral, are thought to have embodied the New Jerusalem as seen by St. John in Revelation 21. Stephen Murray argued in his Beauvais Cathedral: Architecture of Transcendence that it was likely not by chance that the Beauvais choir was as high as it was wide (Revelation 21:16) and that the height of the church was 46.75 metres, or 144 cubits tall (Revelation 21:17). ${ }^{24}$ As a general trend, walls in a Gothic church were

\footnotetext{
${ }^{23}$ Guillaume Durand, The Symbolism of Churches and Church Ornaments, ed. by J.M Neale and Benjamin Webb (Charles Scribner's Sons: New York, 1893), xiv-xvi.

${ }^{24}$ Stephen Murray, Beauvais Cathedral: Architecture of Transcendence (Princeton: Princeton University Press, 1989), 110-111.
} 
metaphorically porous; light filtered through the space, merging with and transfiguring the interior - akin to the idea proposed in Revelation 21:23 that "the city had no need of the sun, neither of the moon, to shine in it: for the glory of God did lighten it." ${ }^{25}$ The stained-glass effect created a gateway for divine, mystical illumination of the interior space. Comparing the Romanesque to the Gothic, Erwin Panofsky portrayed the former church as a structure of determined space that conveyed impenetrability from both the inside and outside. In contrast, the Gothic cathedral was an impenetrable and determined space only from the exterior but "indeterminate and penetrable from within." 26

Bruce Watson argues that such a splend or of light and shadow was created previously through Islamic architecture, though was viewed typically only by royalty. ${ }^{27}$ In the Gothic cathedral, the dazzling light was available now to the general public and would make the medieval Christian viewer eager to make any promise that would enable him to live in such a divine light. ${ }^{28}$ Bathed in this glory, one might "doubt [his] chance of reaching paradise, yet the goal would be as clear as the light itself." ${ }^{29}$ The space was still one of royalty, although now extended to all Christians, who, as children of God, would inherit a celestial kingdom. No longer would physical barriers prevent the Christian from accessing the heavens and the realm of God: unlike the Jewish temple the church was not the location wherein God descended to man. Instead, the Gothic church could be the portal where man was transported to the heavens and to God. The additions of stained glass and the vertical emphasis served to allow a medieval—or

\footnotetext{
${ }^{25}$ Otto von Simson, The Gothic Cathedral (Princeton: Princeton University Press, 1988), 3.

${ }^{26}$ Erwin Panofsky, Gothic Architecture and Scholasticism (New York: World Publishing, 1951), 43.

${ }^{27}$ Bruce Watson, Light: A Radiant History from Creation to the Quantum Age (New York: Bloomsbury, 2016),

${ }^{28}$ Ibid.

${ }^{29}$ Ibid.
} 53. 
modern - Christian audience a resplendent physical space reminiscent of the heavens or the New Jerusalem where they may seek the spiritual presence of God.

The question remains of how an architect can introduce new concepts to a population and is further muddied if the population is also a newly formed community. More specifically, how did the temple of the Church of Jesus Christ of Latter-day Saints create meaning within the early Latter-day Saint community in the western United States and Canada? In contrast to the lightinfused basilica plan of revival churches that were popular in nineteenth-century New England when the Church was established, the early Mormon temple following the Pioneer trek westward adopted walls with small windows and a maze-like layout that directed the patron through a circular progression of multiple rooms (see fig. 2). ${ }^{30}$ The floorplan is representative of the earthly journey through life rather than a celestial realm, and it is only the final room that one visits in the temple ceremony - the Celestial room - that is intended to be a representation of the heavens (see fig. 3). Yet even in the Celestial room, the space is meant to be one of quiet reflection and contemplation; it is a room of peace rather than awe. Talking is discouraged and is to be done only in whispers. The purpose of the room is not to look around oneself and communicate with fellow members of the faith, but to look within. Save for a large chandelier, very rarely is a noteworthy artistic feature displayed in the Celestial room and the intention has been to focus on one's heart rather than one's surroundings. The temple patron is provided an environment where they may be spiritually in the presence of God and must imagine the physical reality of the heavens.

\footnotetext{
${ }^{30}$ A patron is the most common way the Church describes those who are visiting the temple for the purpose of partaking in the temple ceremonies for either themselves or a decea sed relative, this purpose often called "temple work." The patron is distinguished from the "temple worker" who guides the patron through the temple procedures but who is not completing any of the temple ceremonies on their own behalf or on behalf of a decea sed relative. Both temple patrons and temple workers wear the same white clothing.
} 


\section{Latter-day Saint Temples}

Existing Church-published literature about Latter-day temples tends to focus on the sacred nature of the temple's worship ceremonies and does not distinguish between one temple and the next, for all temples are equal in that each temple provides the exact same ordinances and spiritual opportunity. ${ }^{31}$ Intended for a general Latter-day Saint audience rather than an academic one, many Latter-day Saint publications connect the temple with Solomon's temple, discuss the Biblical concept of making covenants with God, or collect faith-building stories of the individuals connected to the building, dedication, and attending of a specific temple. A few historical volumes, however, have been published on architectural or historical analysis of specific temples. In 1978, Laurel B. Andrew published The Early Temples of the Mormons, an extensive collection of research on the history and architecture of the Pioneer temples, being those in St. George, Logan, Manti, and Salt Lake City, and how these temples compared to the earlier edifices in Kirtland and Nauvoo. ${ }^{32}$ V.A. Wood—son of the Card ston temple's first president—published The Alberta Temple: Centre and Symbol of Faith in 1989, which is to date the most detailed history of the temple in Cardston, Alberta. ${ }^{33}$ Paul Anderson, a historian working for the Church of Jesus Christ of Latter-day Saints, published extensively on the mural paintings in temples and has provided much of the significant art historical analysis of $19^{\text {th }}$ and $20^{\text {th }}$-century temples. His employment through the Church decades ago no doubt provided access to many archival files that today are unavailable for further study as the Church has in recent

\footnotetext{
${ }^{31}$ See Gordon B. Hinckley, "Some Thoughts on Temples, Retention of Converts, and Missionary Service," General Conference, Salt Lake City, Utah. October 1997. See also La Rene Porter Gaunt, “Taking Temples to the People," Ensign, March 2000.

${ }^{32}$ Laurel B. Andrew, The Early Temples of the Mormons (Albany: State University of New York Press, 1978).

33 V. A. Wood, The Mormon Temple (Calgary: Detselig Enterprises Limited, 1989).
} 
years restricted nearly all temple archival materials from public access. Thomas Carter's 2015 Building Zion additionally discusses the history and creation of ritual space in the Latter-day Saint temple, focusing on the shifts in ritual administration between the Nauvoo and Pioneer temples. ${ }^{34}$ No specific analysis of the transition between the Pioneer temples and the Cardston temple has been performed.

A few Canadian scholars - none of them members of the Church-have also taken note of the Cardston temple's unique place in Canadian architecture. Jacqueline Hucker's research for Parks Canada was published by the Journal of the Society for the Study of Architecture in Canada in 1998 and titled "The Cardston Temple, Alberta, and Nonconformist Form." 35 The article arrays the details of the Card ston temple, including making the important connection to Frank Lloyd Wright's Unity Temple in Chicago, but with little theological analysis and few points of serious comparison to Unity Temple. Trevor Boddy's Modern Architecture in Alberta (1988) included a brief comment about the Cardston temple, again noting the existence of similarities to Unity Temple but lacking mention of many points of comparison between the buildings. ${ }^{36}$ Maitland, Hucker and Ricketts included a paragraph about and a photograph of the Cardston temple as it stood following renovation in the latter half of the twentieth century in their A Guide to Canadian Architectural Styles (1992). ${ }^{37}$ More recent publications include a twopage spread on the Cardston temple in Richardson and Richardson's Canadian Churches: An Architectural History. ${ }^{38}$ Finally, Brooke Brassard's $2018 \mathrm{PhD}$ dissertation at the University of

\footnotetext{
34 Thomas Carter, "Mansion on the Hill: The Temple as Ritual Space," Chapter 8 in Building Zion: The Material World of Mormon Settlement. (Minneapolis: University of Minnesota Press, 2015).

35 Jacqueline Hucker, "The Cardston Temple, Alberta, and Nonconformist Form," Journal of the Society for the Study of Architecture in Canada 23, no.2 (1998): 55-61.

36 Trevor Boddy, Modern Architecture in Alberta (Regina: Canadian Pla ins Research Centre, 1988), 33-35.

${ }^{37}$ Leslie Maitland, Ja cqueline Hucker, and Shannon Rickets, A Guide to Canadian Architectural Styles (Peterborough: Broadview Press, 1992), 177.

38 Peter Richardson and Douglas Richardson, Canadian Churches: An Architectural History (Buffalo/Richmond Hill: Firefly Books, 2007), 340-342.
} 
Waterloo studied the development of Latter-day Saint identity in Canada and observed the importance of the temple in establishing Southern Alberta as a permanent home for the Latterday Saint community. ${ }^{39}$ A chapter of this dissertation was published as an article titled "Prairie School in the Prairie: An Architectural Journey Through Mormon History in Southern Alberta, $1888-1923$ " by the Journal of Mormon History in $2016 .^{40}$

While not focused specifically on temple history, it is worth noting the recent publication of Carma and Roy Prete's Canadian Mormons: History of the Church of Jesus Christ of Latterday Saints in Canada in 2017. ${ }^{41}$ The volume outlines the Latter-day Saint community in each province or region across the country and takes into account the individuals who laboured diligently to create strong Latter-day Saint communities, especially at times when preparations were being made for the building of various temples throughout the country. It is the first scholarly book to encompass the entirety of Canadian Latter-day Saint history. No previous research, however, produced either by the Church and members of the Latter-day Saint community or by those outside of the Church, has discussed the extent to which the political climate between the Church of Jesus Christ of Latter-day Saints and the American government influenced early temple architecture, and little has been published about the theological teaching that was made possible through the floorplan of early Latter-day Saint temples.

\footnotetext{
${ }^{39}$ Brooke Brassard, "Thirsty Land into Springs of Water: Negotiating a Place in Canada as Latter-day Saints, 1887-1947,” Ph.D. diss., (University of Waterloo, 2018).

40 Brooke Brassard, "Pra irie School in the Prairie: An Architectural Journey throu gh Mormon History in Southern Alberta, 1888-1923," Journal of Mormon History 42, no. 2 (April 2016), 139-167.

${ }^{41}$ Carma and Roy Prete, eds., Canadian Mormons: History of the Church of Jesus Christ of Latter-day Saints in Canada (Provo: Religious Studies Centre, Brigham Young University, 2017).
} 


\section{Church Architecture in Canada}

Fitting the Cardston temple into the corpus of Canadian religious architecture serves somewhat of a daunting task considering the nuances of Canadian religious architecture have been largely overlooked. Peter Coffman, a Canadian architectural historian wrote that "the comparative modesty of the country's architecture has kept it out of 'the canon,' and the lack of a homegrown Wren, Hawksmoor, Soane, or even Jefferson has ensured Canada's absence from survey texts." 42 Even so, the existing scholarship tends to emphasize eastern Canadian provinces. Candace Iron and Malcolm Thurlby's research on Ontario's churches has led to dozens of journal articles, many of which have been published by the Society for the Study of Architecture in Canada. Luc Noppen's prolific writings on Quebec's churches include survey texts and sitespecific publications. Gregg Finley has published multiple articles on church architecture in New Brunswick while Peter Coffman's research has provided a strong foundation for understanding the traditions of Newfoundland's church architecture.

Peter Richardson and Douglas Richardson's monolithic Canadian Churches: An Architectural History, previously mentioned, is perhaps the best anthology of the nation's religious sites and, along with rich illustrations, provides a brief analysis of hundreds of the country's churches. The Cardston temple is offered as the sole example of Mormon architecture despite the dozens of sizable tabernacles, stake centres (large meetinghouses where regional leadership offices are located), seminary and institute buildings, and chapels that the Church of Jesus Christ of Latter-day Saints has built throughout the country in the century since the Church

\footnotetext{
42 Peter Coffman, "The Gibbsian Tradition in Nova Scotia," in Matthew M. Reeve (ed.), Tributes to Pierre du Prey: Architecture and the Classical Tradition, from Pliny to Posterity (London/Turnhout: Harvey Miller Publishers, 2014), 211.
} 
began building worship spaces in Canada. ${ }^{43}$ Listing the Cardston temple as one of "Canada's

most surprising buildings," the authors admit that the Cardston temple was an "unexpected anticipation" of modernism in Canada. ${ }^{44}$ Recognizing Pope and Burton's indebtedness to Frank Lloyd Wright, Richardson and Richardson mention an aesthetic similarity between the Cardston temple and the Imperial Hotel in Tokyo rather than Unity Temple—but provide no analysis (see fig. 4). ${ }^{45}$

\section{Part II: The Latter-day Saints in America}

Since the establishment of the Church of Jesus Christ of Latter-day Saints in 1830, temple building has been among the highest of the Church's priorities. ${ }^{46}$ A temple was built in Kirtland, Ohio, only a few years after the establishment of the Church, and construction on the Nauvoo temple began as soon as the church community arrived in Illinois. A temple had been planned for the town of Independence, Missouri, but persecution caused the Latter-day Saints to flee before the edifice was erected. These first temples were intended to be gathering spaces for weekly worship, administrative meetings, and ritual ordinances, although the purpose of the temple changed dramatically when the Latter-day Saints arrived in Utah. ${ }^{47}$ No longer was the temple to be associated with weekly meetings - a much smaller "meetinghouse" was built to

\footnotetext{
${ }^{43}$ Tabernacles were gathering spaces used especially in the early Church for large events and when members of Church leadership are visiting and speaking. Tabernacles were not built with the classrooms and facilities such as gymna siums that are common to meetinghouse architecture. Tabernacles are not built today, but stake centres, which are large meetinghouses where regional leadership offices are located, fulfill the same purpose. Seminaries and institutes are built where there are large populations of Latter-day Saints, such as in Utah and Alberta, for weekday classes offered to the Church youth and young a dult popula tions. They are often built adjacent to high school or university campuses and the classes run on a semester's schedule. Cha peland meetinghouse are used synonymously as the physical location of Sunday worship services and Latter-day Sa ints refer to these spaces most commonly as churches.

${ }^{44}$ Richardson and Richardson, Canadian Churches, 340.

${ }^{45}$ Ibid, 341.

46 Thomas Carter, Building Zion: The Material World of Mormon Settlement (Minneapolis: University of Minnesota Press, 2015), 242.

${ }^{47}$ Laurel B. Andrew, The Early Temples, 79.
} 
serve each small community - but the temple, larger and less common, was to be solely for the administration of ordinances. These temple ordinances include baptisms, wedding ceremonies (known as a "sealing" as the couple is "sealed" together for eternity rather than until death), and a ritual referred to as the endowment. ${ }^{48}$ Individuals have often travelled long distances to the temple seeking personal inspiration or a specific blessing, whereas weekly scripture study classes and a Eucharistic bread and water ceremony known as "the sacrament" take place at meetinghouses. ${ }^{49}$ While early forms of the temple ord inances were officiated in the Nauvoo temple, the temples in Utah were designed exclusively to administer the temple ordinances to large crowds as they progressed through multiple rooms inside the temple, each representative of a different stage of life and spiritual growth. ${ }^{50}$

As of 2019, the Church manages 161 completed and dedicated temples around the world, although the size, style, and floorplan of the buildings differ greatly, and most bear very little resemblance to the early temples of the Church. ${ }^{51}$ The temples referred to herein as the "early temples" are among the first ten built by the Church following the Mormon exodus to Utah: St. George (1877), Logan (1884), Manti (1888), Salt Lake (1893), Laie (1919), Cardston (1923), Mesa (1927), Idaho Falls (1945), and Los Angeles (1956). These buildings were designed with

\footnotetext{
${ }^{48}$ Packer, Preparing to Enter the Holy Temple, 1.

${ }^{49}$ Stories of Latter-day Sa ints travelling hundreds of kilometers and making extra ordinary sacrifices to attend the temple are common in Church publications. One such example is detailed by Claudio R. M. Costa, "Gather to the Temple," Ensign, December 2008. He explains that "some Latter-day Sa ints... were so determined to go to the temple that they sold their homes, means of transportation, work tools - anything of value - to raise money." In the October 2008 General Conference, Silvia H. Allred described her experience organizing a trip for Church members in Costa Rica and neighbouring countries in Central America to attend the temple in Mesa, Arizona, which was at the time their nearest temple. "The trip required us to travel five days each way, crossing six borders. The financial sacrifice formost of those who went was great... some of the members had used all their money to pay for the bus fare and had taken only crackers and margarine to eat on the way." See Silvia H. Allred, "Holy Temples, Sacred Covenants," GeneralConference, Salt Lake City, Utah. October 2008.

${ }^{50}$ The St. George temple's original floorplan did not follow the same progressive plan as the other Pioneer temples, but it was later renovated to facilita te the same motion of movement throughout the temple.

51 “2018 Statistical Report for 2019 April Conference," Newsroom of the Church of Jesus Christ of Latter-day Saints, 6 April 2019.
} 
the specific intent of officiating the endowment ceremony in a way that communicates, through architecture, the sacred nature of not only the building but the ritual in which the temple patron takes part. As such, the early temples featured a progressive floor plan where temple patrons physically advanced from a lower room to a more elevated room, following the trajectory of Adam and Eve in the Garden of Eden as they are given further knowledge and make covenants with God throughout their life. The endowment ceremony was historically acted out and officiated by temple volunteers for groups of sometimes only five or ten patrons, while a busy ceremony might include several dozen people. After each patron receives further knowledge, tokens and signs, and makes covenants in each stage of the ceremony, the group moves into a room at a higher elevation, symbolically drawing closer to the presence of God (refer again to fig. 2).

Today, the endowment ceremony is typically constrained to a single room and the ceremony is delivered through a film presentation rather than the use of volunteer actors. The Los Angeles temple was the final temple to be designed for a live, acted presentation of the endowment rather than a film presentation and therefore bears the same progressive floor plan as the other early temples. In contrast, the above list specifically excludes the Bern, Switzerland temple (1955), built one year prior to the Los Angeles temple and which was the first temple designed for the film endowment presentation in a single room. ${ }^{52}$ No temples following the Los Angeles temple were built with a progressive floor plan. ${ }^{53}$

\footnotetext{
52 For a discussion of the origins of the film endowment presentation, see Sheri Dew, Go Forward with Faith: The Biography of Gordon B. Hinckley (Salt Lake City, Utah: Deseret Book Company, 1996), 176-193, and Claudia L. Bushman, Contemporary Mormonism (Westport: Praeger, 2006), 78.

${ }^{53}$ Also noteworthy is that the list of standardized temple chronology begins with St. George as number one, although two temples had been built previously: one in Kirtland, Ohio (1836), which is owned by the Community of Christ, and one in Nauvoo, Illinois (1846), which was sold and subsequently destroyed by fire. Additionally, the date associated with each temple marks the dedication date; the gro und-breaking for the Salt Lake temple occurred in 1853-long before the nearby temples of St. George, Logan, and Manti, also of Utah — although it was the fourth
} 
The proto-temples in Kirtland and Nauvoo, predating the Mormon exodus and the progressive temple floor plan, bear the unique mark that their architectural plans are consistently attributed to having been revealed directly to the prophet Joseph Smith in a vision and thus little consideration is given to the impact of their architect. ${ }^{54}$ The Kirtland temple had been built in a style reminiscent of colonial America, following careful proportions with low pediments, a bell tower, and dormer windows protruding above the second floor along the sides of the building (see fig. 5).${ }^{55}$ Classical, arched windows reminiscent of Serliana windows adorned each end of the building while the sides of the temple were decorated with Gothic lancet windows. Through Joseph Smith's perceived role of architect, at least for the Kirtland temple, one modern Latterday Saint newspaper compared him to Moses, receiving through revelation from God the detailed instructions on how to build the tabernacle in the wilderness. ${ }^{56}$ The role of the Church leader in temple-building strengthened his claim of divine leadership.

The Nauvoo temple, while still bearing a central bell tower at the front, was a more sophisticated design following more defined classical traditions. William Weekes, the architect whose design was carefully approved by Joseph Smith, was a New England builder whose training is unknown but is speculated to have been "of the Greek Revival school." ${ }^{57}$ It is important to note that Weekes was working within a well-established Protestant framework that

temple completed in 1893, and the Cardston temple was begun before Laie, although their dedication dates place them in a different chronology.

${ }^{54}$ J. Earl Arrington, "William Weekes, Architect of the Nauvoo Temple," BYU Studies Quarterly 19, no. 3 (1979), 340. See also Saints: The Story of the Church of Jesus Christ in the Latter Days, v. 1 (Salt Lake City: The Church of Jesus Christ of Latter-day Saints, 2018), 169. While the Salt Lake temple was shown to Brigham Young in a vision, the role of the architect was significantly augmented in the Pioneer temple era. See Brigham Young, April 6, 1853, Journal of Discourses (London: LDS Booksellers Depot, 1854-86), 1:133.

55 A larger analysis of the Kirtland and Nauvoo temples is written by Laurel B. Andrew in her chapters "TempleBuilding Begins," and "Ritualand Symbolism at Nauvoo," in The Early Temples of the Mormons (Albany: State University of New York Press, 1978), 29-97.

56 Daniel Peterson, "The Inspired Plans for the Kirtland Temple," Deseret News, 20 Oct 2016.

57 Arrington, "William Weekes," 340. See also Marjorie H. Bennion, "William Weeks' Nauvoo Temple Drawings," Mormon Historical Studies 31 (Spring 2002), 75. 
traces to James Gibbs' St. Martin-in-the-Fields, a church with which the Nauvoo temple shares many similarities. ${ }^{58}$ The Gibbsian tradition was brought to North America via the 1728 A Book of Architecture written by Gibbs himself. It is unknown if Weekes may have owned or had access to a copy of $A$ Book of Architecture, but he certainly did consult published volumes as he prepared his drawings for Nauvoo: Edward Shaw's Civil Architecture was in his personal collection and briefly mentions Gibbs' famous St. Martin-in-the-Fields in the opening pages among a discussion of classical orders and columns. ${ }^{59}$

Surrounded by a series of thick pilasters topped with unusual sunstone capitals, the Nauvoo temple resembled a hexastyle Roman temple topped by a massive $19^{\text {th }}$-century tower, not unlike the one rising above the Lond on building. A triangular pediment was originally planned, although eliminated before construction began, and the simple entablature bore an allusion to a triglyph-and-metope frieze (see fig. 6 and 7). In both the Nauvoo temple and St. Martin-in-the-Fields, the central staircase led to the tripartite arched entrance. The similarity to St. Martin-in-the-Fields is discussed by Laurel B. Andrew who points out that the balustrade along the roof of the temple, which runs abruptly into the pediment is "not a Greek Revival design, nor was it usually found on Georgian churches in America. It does occupy precisely the same position as its counterpart in the Gibbs engraving" in the pattern book. ${ }^{60}$ Knowing that Weekes consulted architectural publications, it is not unreasonable to propose that he may indeed have sourced Gibbs' drawings, and would not have been the first North American architect to do so: the eighteenth-century church of St. Paul's, in Halifax, Nova Scotia, was dependent on

\footnotetext{
${ }^{58}$ Laurel B. Andrew, The Early Temples, 71.

59 The Church History Library in Salt Lake City is now in possession of Weekes' copy of Shaw's Civil Architecture. A brief mention of St. Martin-in-the-Fields is made on pa ge 10, though Gibbs' name is not referred to anywhere in the volume. See Edward Shaw, Civil Architecture: Or a Complete Theoretical and Practical System of Building (Boston: Marsh, Capen \& Lyon, 1832), 10.

${ }^{60}$ Andrew, The Early Temples, 71.
} 
Gibbs' Marybone Chapel, engravings of which were published in Gibbs' pattern book. St. Paul's contains features comparable to both the Kirtland and Nauvoo structures (see fig. 8). ${ }^{61}$ The resemblance, however, for any of the above-mentioned buildings is comparable only in the exterior.

The arrival of the Latter-day Saints in Utah initiated a change not only in the temple's division of interior space-which would now be focused on the progressive-room style to facilitate the endowment ceremony, rather than providing large general meeting spaces for public gatherings - but also in the temple's exterior architecture. In contrast to the classical influence that was evident in the Kirtland and Nauvoo designs, the four temples designed in Utah at the end of the nineteenth century were each constructed in a crenellated medievalized style, referred to by Laurel B. Andrew as the "castellated Gothic" (see figs. 9-12). ${ }^{62}$ While some features, such as classical bell towers and roughly symmetrical facades, remain indebted to the Gibbsian tradition, the pediments and pilasters were replaced with castellated rooflines and buttresses of a defensive and impermeable stronghold. Combinations of rounded and Gothic windows were used within the same building. Rather than a plastered white surface, the Manti, Logan, and Salt Lake temples were adorned with nothing but their smooth masonry.

The unique, medievalized style of the Utah temples did not outlive the $19^{\text {th }}$ century. The architecture of the Cardston Alberta temple, completed in 1923, dramatically breaks from the Gothic influence of the temple buildings in Utah in favour of a Prairie-school inspired modernist building (see fig. 13). While these stylistic divisions have been noted, they have never before been used as evidence of the complex relationship between the Church and the United States of America. This section provides an analysis of early Latter-day Saint temple architecture as a

\footnotetext{
61 Richardson and Richardson, 44.

${ }^{62}$ Andrew, The Early Temples, 12, 136.
} 
commentary of the Church's views on American society, demonstrating that the four Utah temples were intended to break with the American classical tradition following the Mormon exodus to Mexico. The social history of the Church of Jesus Christ of Latter-day Saints in the United States will first be established, followed by an analysis of the Utah Pioneer temples.

\section{$19^{\text {th }}$ Century Mormons and the American Government}

Brigham Young, a native of Vermont, emerged as the zealous and Zionistic church leader following the 1844 murder of the Church's founder, Joseph Smith. Committed to the establishment of a permanent Mormon homeland, Young had originally remained drawn to the protection of the American constitution and by 1845 had sought asylum for the Latter-day Saints from every state and territory governor in the United States. His request was denied by all, either ignored or rejected altogether. ${ }^{63}$ Three congressmen arrived to negotiate with Young, encouraging, or perhaps demanding, that he and his people leave the "confines of the United States and of the public domain." ${ }^{64}$ His remaining options were either Mexico or Vancouver Island; Young took the Saints to Mexico and found himself a year later annexed back into the United States when the expanding nation won the Mexican War. ${ }^{65}$

The move westward prompted not only the idea of a physical separation from their oppressors, but an ideological separation from the American nation as well. Brigham Young became a vehement critic of the American government, blaming the political structure as a whole for the death of Joseph Smith and explaining that the Mormon people "have been driven from

${ }^{63}$ Journal of Discourses, (London: LDS Booksellers Depot, 1854-86), 11:18.

${ }^{64}$ Ibid.

${ }^{65}$ Much is written about Vancouver Island as a potentialdestination; see especially A History of the Mormon Church in Canada (Lethbridge: The Lethbridge Alberta Stake, 1968), 16-17, and Richard Bennett and Arran Jewsbury, "The Lion and the Emperor: The Mormons, The Hudson's Bay Company, and Vancouver Island, 1846 1858, BC Studies no. 128 (Winter 2000/2001), 45. 
state to state, and Joseph and Hyrum, our Prophet and Patriarch, were murdered in cold blood, while in government duress, and under the immediate control, inspection, and supervision of the governor and government officers." ${ }^{96}$ This disdain quickly became a part of the Mormon religious tradition when the endowment ceremony adopted an Oath of Vengeance as part of the temple ritual. The oath was first administered as part of the ceremony in 1845 and was "routinely given to all initiates," where members of the Church were instructed to "covenant and promise that you will pray, and never cease to pray, Almighty God to avenge the blood of the prophets upon this nation." ${ }^{\prime \prime 7}$ A song written to honour the prophet Joseph Smith included the words "long shall his blood, which was shed by assassins, stain Illinois while the earth lauds his fame." ${ }^{\prime 68}$ The verbiage has since removed "stain Illinois" in favour "plead unto Heav'n" and the song continues to be among the most popular in the Latter-day Saint hymnal. ${ }^{69}$

Knowing that the westward spread of American influence was inevitable, that individual states were awarded a large amount of autonomy, and that the Mormon community could live comfortably under the American constitution, Young applied for statehood. Utah was separated by the Rocky Mountains from the rest of the United States, and Brigham Young hoped to see statehood while maintaining cultural independence. He advocated for the Saints' right to peaceably live their religion in isolation, commenting that "if the people of the United States do not like our religious institutions, they are not compelled to mix in our society, or associate with us, or with our children." 70

\footnotetext{
${ }^{66}$ Susa Young Gates, The Life Story of Brigham Young (Freeport: Books for Libraries Press, 1930), 133.

${ }^{67}$ David Buerger, “The Development of the Mormon Temple Endowment Ceremony," Dialogue: A Journal of Mormon Thought 20, n. 4 (Winter 1987), 52.

68 "Joseph Smith," Times and Seasons 5, no. 14 (Aug 1, 1844), 607.

69 "Praise to the Man," Hymns, Salt Lake City, UT: The Church of Jesus Christ of Latter-day Saints, 1981.

${ }^{70}$ Journal of Discourses, 2:177.
} 
The application was rejected. The land was, however, designated as the American territory of Utah on September 9, 1850. Young was the governor and he intended for the territory's theocracy to be independently governed ${ }^{71}$ Fearing further government intervention in the lives of the Saints, he spoke defensively and cautioned the Mormon community that when "[the American armies] come here to take our lives solely for our religion, be ye also ready." Talking about American troops stationed near Salt Lake City during the Utah War, he exclaimed: "I do not often get angry; but when I do, I am righteously angry; and the bosom of the Almighty burns with anger towards those scoundrels; and they shall be consumed, in the name of Israel's God. We have borne enough of their oppression and hellish abuse, and we will not bear any more of it!" 73

Territories, however, were not granted the full rights of statehood, including the ability to independently choose leaders. When James Buchanan became the American president in 1857, he wasted no time exercising his authority over the territory and replacing Young with a new, non-Mormon governor; Alfred Cumming was appointed the following year. Young reiterated his commitment to obtaining statehood for Utah: "It is not the laws and constitution of our country that we wish to be free from, but it is from the power of those who profess to be lawmakers and law executioners, but who trample every wholesome law under their feet." ${ }^{94}$ In 1863 , he lashed out against the "gentile" government officials whose "d esign is to interrupt and disturb the peace of this people," wondering if the "strong arm of military power" was responsible for encouraging persecution of the Saints in their new Mormon homeland. ${ }^{75}$ Young later announced angrily in a

\footnotetext{
${ }^{71}$ See Chapter 1, "The Political Kingdom of God," in Gustive O. Larson, The “Americanization” of Utah For Statehood (San Marino, Ca lifornia: The Huntington Library, 1971), 1-10.

72 Journal of Discourses, 5:127.

73 Journal of Discourses, 5:227.

${ }^{74}$ Journal of Discourses, 5:351.

75 Ibid, 10:254.
} 
church address that the Mormons would either have to "go somewhere" or "fight the whole world." The Saints had already moved a half a dozen times and had nowhere else to go, and Young was adamant that "King James Buchanan" had not succeeded (and would not succeed) in removing them. ${ }^{76}$

Nationalistic Ideology of the Pioneer Temples and Separation from American Architecture

Brigham Young not only believed that much of the United States government was corrupt, but that their architectural choices were susceptible to erosion. When it came to temple building in Utah, Young's distaste of the American government was built directly into the architecture and choice of building material for the St. George, Logan, Manti, and Salt Lake City temples - referred to as the Pioneer temples. The temple was intended to symbolize a place where the religious rule was established, where order was created, and where leadership administered to the people - it was the symbol of the "government of God." "77 In many ways, it was to be a parallel to the American Capitol building (see fig. 14). The Capitol's architecture, however, became a source of ridicule in one of Young's 1852 sermons as he promoted the superiority of adobe over stone as a building material:

"The House of Representatives was rebuilt in 1812, not more than forty years ago. Would any of you that have not been there, suppose that it would need patching up already to make it comfortable for the representatives of the nation? This, however, is the case, for within ten years past eighty thousand tons of putty have been used to putty up the places where the stone has decayed by the operation of the elements, and it has not been built forty years." 78

\footnotetext{
${ }^{76}$ Ibid, 14:108.

77 Andrew, Laurel B, “The Nineteenth-Century Temple Architecture of the Latter-day Sa ints," Ph.D. diss., (University of Michigan, 1973), 155.

${ }^{78}$ Journal of Discourses, 1:220.
} 
Young, however, wanted a temple that would "endure through the millennium."79 Inspired by the longevity of medieval architecture, Young sent church architect Truman Angell to England as a missionary to both preach the gospel and learn from the ideologies and methodologies of historic architecture ${ }^{80} \mathrm{He}$ was particularly impressed by the "masterful style of architecture" he saw at the Hereford Cathedral in January $1857 .{ }^{81}$ The nineteenth-century blending of Romanesque and Gothic revival styles represented a connection to the past, and members of the Church of Jesus Christ of Latter-day Saints believed that their church was established as a restoration of Christ's original, first-century church with priesthood "lineage to the time of Christ." 82 The medieval architectural principles adopted by the Pioneer temples connected the nineteenth-century Church to an ancient Christian community, an idea that was already popular in England through architects such as Pugin who denounced Classical architecture for its pagan associations. ${ }^{83}$ The classically-styled Nauvoo temple had burnt to the ground and Young intended to build temples that were "substantial," permanent, strong and impenetrable, and renowned for their "beauty and excellency." 84 The new temple was not only intended to match the European Gothic churches in durability, strength, and defensibility, but to be physically stronger than the American oppositional forces that had overcome and destroyed the temple in Nauvoo. The "castellated Gothic could summon thoughts of indestructibility and

\footnotetext{
${ }^{79}$ Ibid, 10:254.

${ }^{80}$ See Paul L. Anderson, “Truman O. Angell" Architect and Saint," in Supporting Saints: Life Stories of Nineteenth-Century Mormons (Provo, UT: Religious Studies Center, Brigham Young University, 1985), 133-73.

${ }^{81}$ Truman O. Angell, "Truman O. Angell, 1810-1887: Autobiography," published in Our Pioneer Heritage 10 (1967), a vailable online at https://www.boap.org/LDS/Early-Saints/TAngell.html.

${ }^{82}$ Brooke Brassard, "Prairie School in the Prairie: An Architectural Journey through Mormon History in Southern Alberta, 1888-1923," Journal of Mormon History 42, no. 2 (April 2016), 146.

${ }^{83}$ A. Welby Pugin, An Apology for the Revival of Christian Architecture in England (London: John Weale, 1843), 22.

${ }^{84}$ Journal of Discourses, 10:252-4.
} 
defensibility," represent a Church-instituted "governmental authority" and further demonstrated the separationist, "cloistered life of the medieval scholar." 85

Brigham Young's initial goal was not only to avoid the Neoclassical style of the American Capitol building, but to avoid the use of stone entirely. He considered himself a "chemist in theory" and possessed the flawed idea that stone was in a state of decay and adobe, or mud, would harden into stone. ${ }^{86} \mathrm{He}$ even believed the Egyptian pyramids were built of adobe, and in his mind envisioned that the Latter-day temple, a thousand years hence, would become a similar icon of a civilization's apex ${ }^{87}$ His other proposed methods were to build the temple entirely from "platina," a chemical compound thought to be a new element but really was just a mixture of others; he proposed pure gold if platina were not an option; iron or brass even, would be better than stone. ${ }^{88}$ In an urge, however, to separate from the Neoclassical style of American ideals as he established an independent kingdom of God, the Mormon "Deseret," Young was eventually persuaded to opt for stone and the impressive Gothic verticality that it offered - a feature that the adobe could not provide ${ }^{89}$ The four Pioneer temples were built from local volcanic rock, granite, quartzite, or limestone. While many American churches throughout the nineteenth century turned to a Gothic revival architectural language, the unique fortress qualities of the Latter-day Saints were intended, I propose, to contrast not only with American religious architecture but political architecture as well.

\footnotetext{
${ }^{85}$ Andrew, The Early Temples, 136.

${ }^{86}$ Ibid, $1: 219$.

${ }^{87}$ Ibid.

${ }^{88}$ Ibid, $1: 218$.

${ }^{89}$ Andrew, The Early Temples, 100.
} 
Transition "From Satyr to Saint:" Reintegration into American Society

In 2006, Jan Shipps, among the most prominent of non-Mormon scholars on Latter-day Saint history, published the results of a survey conducted regarding the Mormon public image throughout the nineteenth and twentieth centuries in a book chapter titled "From Satyr to Saint." She concluded that the years between 1896 and 1920 were noticeably "years of transition from the pioneer to the modern world," citing a previous study by S. George Ellsworth, a twentiethcentury American historian. ${ }^{90}$ While the Latter-day Saints once represented seemingly everything American culture disavowed, including polygamy, communal economic structures and theocratic government, by the late twentieth century they had come to represent what an American ought to be: self-sufficient, engaged citizens who believed in principles of chastity and fidelity. ${ }^{91}$

Yet in the nineteenth century, while the Mormon pioneer perspective of American leadership was markedly negative, the portrayal of the church's faith in American culture was no better. Lumped with the Catholics and the Masons, the Mormons between 1830 and 1847, prior to departing for Utah, were part of a trio of communities that Jacksonian America viewed as a threat to their "national ideals, including republicanism and morality."92 The Church's practices of polygamy and theocracy were unbecoming in the eyes of the American public, and it was only the Civil War that brought the government's intent to deal with the "Mormon problem" to a

\footnotetext{
${ }^{90}$ Jan Shipps, Sojourner in the Promised Land: Forty Years Among the Mormons (Chicago: University of Illinois Press, 2000), 66.

91 Ibid, 73.

92 Reid Neilson, Exhibiting Mormonism: The Latter-day Saints and the 1893 Chicago World's Fair (Oxford: Oxford University Press, 2011), 5.
} 
halt. ${ }^{93}$ In the words of Reid Neilson's Exhibiting Mormonism, "Mormonism and Americanism were thus depicted as mutually exclusive concepts." ${ }^{.94}$

After 1847, isolated on the western side of the Rocky Mountains, the Latter-day Saint community had little contact with their American neighbours save through missionary efforts; little was done to build relationships or find solidarity with other Christian denominations. In fact, the Church of Jesus Christ of Latter-day Saints eagerly emphasized the differences between their doctrine and the doctrine of Protestant America, rather than seeking to find common ground ${ }^{95}$ This technique admittedly worked well to attract new converts—-for why, Neilson questions, would Americans join the Church if it offered nothing new from traditional Christianity—but gained the Church few friends outside of Utah. ${ }^{96}$

The relationship between Utah Territory and the United States began to change in the last decade of the nineteenth century. Ceding to American Congress and with the passage of the Edmunds-Tucker anti-polygamy act, the Church formally, and within a generation, culturally, abolished polygamy with the 1890 Manifesto, a document outlining the Church's new policy on monogamy. Utah's petitions for statehood had still gone unanswered, although the theocratic nature of Utah's political environment was reduced when the People's Party, a political party backed by the church, was disbanded in $1891 .{ }^{97}$ Only two years later, the first public presentation of Latter-day Saints, by the church members themselves, was exhibited at the 1893 Chicago World's Fair, a true turning point in the Church's history. While members of the Church had travelled to attend previous international events, never before had Utah - or the Church—

\footnotetext{
${ }_{93}^{9}$ Ibid, 15. See also Shipps, Soujourner in a Promised Land, 62.

${ }^{94}$ Neilson, 6.

${ }^{95}$ Ibid.

${ }^{96}$ Ibid, 46.

${ }^{97}$ Gustive O. Larson, The "Americanization" of Utah for Statehood," 287.
} 
attempted to represent themselves to the general public outside of missionary proselytizing efforts.

The elaborate Utah Building at the Chicago World's Fair did not resemble the defensive architecture of the territory's four Latter-day Saint temples. Rather than a castellated, Gothicinspired fortress, the Utah building was an inviting classical villa with a rounded Doric portico, engaged Ionic pilasters, geometric patterning along the roofline, arched windows and a grand stairway outside the entrance engulfed by a delicate handrail (see fig. 15). Designed by the Salt Lake City architects Dallas \& Hedges, the Utah Building was well at home in the White City that was Daniel Burnham's lived vision of the American classical style. ${ }^{98}$ For arguably the first time, the Mormon image could fit in with the American mosaic. Not only did their exhibit highlight the beautiful landscape of Utah, but the progress that the Latter-day Saints had made in cultivating the land. Agricultural and mining exhibits were intended to attract new workers to the territory and were the recipients of multiple awards due to the diversity and quality of Utah's plentiful specimens. 99 The World's Fair offered Utahns the opportunity to "remake their image and refashion their appearance in Jackson Park on the world's largest stage" and the Mormons felt that at the very least that they had served their purpose of promoting a good name for both the territory and the Church — that the "good seed sown will continue to bear fruit for years to come." 100

In 1896, Utah's repeated petitions for statehood were finally fruitful as the state was admitted to the Union. Brigham Young had died in 1877, after bearing the responsibility of

\footnotetext{
${ }^{98}$ Rand, McNally and Company's Handbook of the World's Columbian Exposition (Chicago: Rand, McNally and Company, 1893), 198-199. The architects worked primarily with residential commissions rather than Church architecture, and designed a variety of Victorian and Queen Anne structures in the Salt Lake Valley - the classical style seems as much an a nomaly for the architects as it does for the Church. See Allen D. Roberts, Salt Lake city's Historic Architecture (Charleston: Arcadia Publishing, 2012), 43, 114, 118-119.

${ }^{99}$ Neilson, Exhibiting Mormonism, 68-69.

100 Ibid, 73-74.
} 
overseeing the construction of the four pioneer temples yet seeing the completion of only one, and entrance to the American confederation would change how the political discourse was manifest in temple architecture. Despite these steps, the Church continued to practice the antiAmerican Oath of Vengeance in the temple ritual. The angst caused by this incongruity was made evident when Reed Smoot, an apostle in the Church's primary body of leadership, was elected as the Utah senator in 1903. A special Senate subcommittee was formed by the Senate to determine whether Smoot should be allowed to serve in the American government, in part due to the potential conflicting oaths that Reed would be required to undertake: his religious oath to avenge the blood of Joseph and Hyrum Smith upon the American nation, and the oath of loyalty to the American constitution to which he would be bound as an American senator. ${ }^{101}$ Although the Oath of Vengeance continued to be administered for another decade and a half, not being eradicated until the mid 1920s when all temple presidents were directed to "omit from the prayer circles all reference to avenging the blood of the Prophets," the Church between 1890 and the second decade of the twentieth century began to undertake remarkable measures to identify with, and realign with, American values. ${ }^{102}$ This shift was reflected not only in church policy and cultural practice, but in architecture. Following the example of the Utah Building at the Chicago World's Fair, the Utah State Capitol building, constructed between 1912 and 1916, was built in remarkable similarity to the American Capitol in Washington D.C. that only half a century prior Brigham Young had so despised. The next temple to be built by the Church, however, would truly demonstrate the shift that had occurred in the Latter-day Saint mindset; skipping entirely

\footnotetext{
${ }^{101}$ Buerger, "The Development," 52. The Mormon practice of polygamy is also cited as a rea son that the Senate was wary of Mormon politicians.

102 Ibid, 55.
} 
over the American classical, the temple built in Cardston, Alberta, adopted the new American modern design influenced by Frank Lloyd Wright's Prairie School style.

\section{The Function of the Temple as Sacred Space}

The temple-building emphasis of the Latter-day Saints made them a peculiarity in the American religious scene, though the careful development of space within the temple followed historic and international designations of sacred space. Unlike the predecessors in Kirt land and Nauvoo, which had been intended as common meeting areas for the Church population, the Pioneer temples and all temples built thereafter were uniquely established to accommodate the endowment ritual. The sacred architecture theorist Joel Brereton described in his encyclopedia article "Sacred Space" that sacred space might be categorized into one of the following three uses: a place of communication between worshippers and the deity, a place where healing or saving ordinances take place, and an "icon of the world" wherein the temple layout provides a metaphor for the participant on how to return to live with God. ${ }^{103}$ While many religious structures might fulfil one, or sometimes two of these purposes, the early Mormon temple fulfils for its members all three.

\section{Communication with God}

Inscribed upon the entryway of each Latter-day Saint temple are the phrases "Holiness to the Lord" and "The House of the Lord." As the house of deity, each Latter-day Saint temple draws from the symbolism of Solomon's Temple and is adorned with the finest materials,

\footnotetext{
${ }^{103}$ Joel P. Brereton, “Sacred Space," In The Encyclopedia of Religion, ed. Mircea Eliade, vol. 11 (New York: Macmillan, 1987), 530.
} 
standing as a "physical presence of God's earthly presence." 104 The temple allows

communication with the deity foremost by being set apart as the dwelling of God. For members of the Church of Jesus Christ of Latter-day Saints, the aspect of communication is a central aspect of their belief: the ability to receive personal revelation is a fundamental aspect of Church doctrine. ${ }^{105}$

Each Latter-day Saint temple provides the exact same unique opportunity for communication with God, whether the temple is in Salt Lake City, Utah, or Sapporo, Japan. While Church members are entitled to personal revelation anywhere and at any time, members are often encouraged to attend the temple seeking inspiration or answers to deeply spiritual and personal questions. In the children's curriculum, the concept of revelation in the temple was broken down simply by explaining that "the temple is a place where... worthy people may go to receive special guidance from Heavenly Father. It is a place of revelation - a place where Heavenly Father reveals, or answers questions about, sacred matters." ${ }^{106}$ As the exact same ceremonies are performed in each temple around the world, no priority is given to attending one temple over another; the emphasis is simply on "attending the temple."107

As a house of God, the Latter-day Saint temple is full of symbols that link the space between the world of Heaven and the mortal world. ${ }^{108}$ The temple has a clearly marked threshold between profane and sacred space at the recommend desk, where each patron is asked to show a card signed by their local ecclesiastical leader granting them entrance to any Latter-day Saint temple around the world. The recommend is given to active church members whose lifestyle is

\footnotetext{
104 Mark C. Hamilton, "Temples," in Nineteenth Century Mormon Architecture and City Planning (Oxford: Oxford University Press, 1995), 33.

${ }^{105}$ Russel M. Nelson, "Revelation for the Church, Revelation for our Lives," General Conference, Salt Lake City, Utah. April 2018.

106 "Sharing Time: The Temple is a Place of Revelation," Friend, May 1993.

107 "Questions and Answers," Ensign, June 2014.

108 Joel P. Brereton, "Sacred Space," 528.
} 
aligned with the values of the church and who are deemed spiritually prepared to enter or maintain a covenant relationship with God. ${ }^{109}$ Living worthy of a temple admittance can be viewed as a type of sacrifice, for, rather than offering animal sacrifices as was done in Solomon's Temple, sacrifices of lifestyle are offered - these include staunch observance of premarital chastity and complete marital fidelity, the abstinence of alcohol, tobacco, and coffee, regular church attendance, and the payment of a tithe. It is as one passes beyond the recommend desk that passage from "the profane to the sacred world becomes possible." 110

As a place of communication with God, temple-goers are encouraged to prepare for their visit to the temple not only spiritually, by proving worthy, but physically as well. Attendees are encouraged to wear church-appropriate clothing; for women, this means a modest skirt or dress (pants or slacks of any type have traditionally been uncommon), and for men a suit. Upon admittance to the temple, however, each patron changes into white clothing to symbolise purity, worthiness, and equality before the Lord. ${ }^{111}$

Once a Latter-day Saint has proven worthy for temple worship, arrived at a temple and changed into white clothing, they are prepared for the communication that ensues as the central purpose of the temple visit. The ordinance referred to as the endowment provides instruction to the participant relative to the "Lord's purposes and plans." ${ }^{112}$ Church president Russell M. Nelson instructed members in October 2018 to be in the temple on a "regular basis" to receive the "spiritual strengthening and tutoring that is possibly only in the House of the Lord." 113 As a

\footnotetext{
109 “Gospel Topics: Temples," The Church of Jesus Christ of Latter-day Saints, n.d. Accessed 3 March 2020. https://www.churchofjesuschrist.org/study/manual/gospel-topics/temples?lang=eng.

${ }_{110}$ Mircea Eliade, "Sacred Space and Making the World Sacred," Chap. 1 in The Sacred and the Profane: The Nature of Religion (New York: Harper, 1959), 25.

${ }^{111}$ Packer, Preparing to Enter the Holy Temple, 16. See also “Gospel Topics: Temples," The Church of Jesus

112 Bruce R. McConkie, Mormon Doctrine, 2nd ed (Salt Lake City: Bookscraft, 1966), 227.

113 Russell M. Nelson, “Becoming Exemplary Latter-day Sa ints." General Conference, Salt Lake City, Utah. October 2018 .
} Christ. 
site of instruction and learning, individuals often attend the temple seeking answers to personal questions, for "the temple is a place of revelation" and it is taught that "every person who enters this sacred place in faith and prayer will find help in the solution of life's problems." 114 The opportunity for and promise of communication between the temple patron and the deity is one clear way that the temple is designated as sacred space.

\section{Healing and Saving Ordinances}

Dressed in white, all participants in temple ordinances are equal to approach God and seek either personal revelation or a blessing of healing. Members of the Church might attend the temple seeking healing blessings for themselves or on behalf of a loved one, although approaching deity with this request is done symbolically; few sculptures or images are generally displayed in Latter-day Saint temples, and the images that are displayed are decorative - prints are often favoured over original works of art—rather than ritualistic in any way. Unlike a pilgrimage church that in Catholicism might also be associated with healing or salvation, and which is likely built to contain a specific relic or object with a tradition of miraculous healing, the Latter-day Saint tradition never promotes the visiting of a certain temple over another. Each temple is instead equipped with a prayer roll where the names of the sick or afflicted are placed by temple patrons on a list. During endowment ceremonies, the names are placed upon the altar of the temple and a prayer at the conclusion of the ceremony includes the petition that God will heal and comfort those whose names are found on the prayer roll list.

More central to the whole temple purpose, however, is the saving nature of Latter-day Saint temple work, which believers hold to be essential for each person to enter the kingdom of God following judgement. Church doctrine demands that all people receive temple ordinances to

114 John A. Widtsoe, “Looking Toward the Temple," Ensign, February 2010. 
receive eternal salvation, including those who lived prior to the establishment of Latter-day Saint temples; therefore, proxy ordinances for the deceased are performed by the living. ${ }^{115}$ Since most people throughout history have not been alive while the Latter-day Saint temple has been accessible (since the founding of the Church in 1830), Church members have become fervent genealogists, seeking names of deceased ancestors for whom proxy temple work can be performed. After a living individual has completed their own temple ceremonies for the first time, subsequent ord inance ceremonies are always done on behalf of a deceased person, who is then offered the "blessings of eternity" should the deceased choose to accept the ordinances performed on their behalf. ${ }^{116}$ Proxy temple work, performed by the living on behalf of deceased ancestors, allows members of the Church to participate in the temple rituals of the endowment ceremony multiple times throughout their life, thus closely linking the temple ritual with the salvation of another. Joseph Smith, the Church's founder, taught adamantly in a sermon that has been canonized in Latter-day Saint scripture that "they without us cannot be made perfectneither can we without our dead be made perfect." ${ }^{117}$ The process of being perfected, in Latterday Saint teaching, hinges on participating in temple ordinances for deceased relatives. Both healing and saving ordinances are crucial to creating the idea of sacred space for Latter-day Saints as they participate in temple activities.

\section{An Icon of the World}

Finally, the Latter-day Saint temple serves as what Brereton calls an "icon of the world." 118 The temple provides a metaphor for the eternal life of the faithful, and its architectural design plays a key role in providing this doctrine. Unlike a cathedral, the interior of a Latter-day

\footnotetext{
${ }_{115}$ Dallin H. Oaks, "Truth and the Plan." General Conference, Salt Lake City, Utah. October 2018.

116 Dieter F. Uchtdorf, "Believe, Love, Do." General Conference, Salt Lake City, Utah. October 2018.

117 Doctrine and Covenants 128:15.

118 Joel P. Brereton, "Sacred Space," 530.
} 
Saint temple is not one open worship space, but is instead broken into many smaller rooms, each with a specific purpose. Different ordinances are performed in particular places in the building, with the first ordinance of baptism being performed in the basement and the final stage of the temple endowment concluding with the participant passing through a veil into the celestial room, which is the room that symbolises the presence of God, at the highest physical part of the temple. This represents the temple patron's journey through mortal life, from birth in the waters of baptism to the experiences of learning and being tested in mortality and finally, if faithful, returning to the presence of God after death. Blessings that may be fulfilled in this life or the next are pronounced upon the temple worshipper, for the covenants are viewed as eternal rather than for only life on Earth. By participating in the temple ordinances, the patron receives instruction and inspiration on how to act both in this life and the next. The ceremony teaches faithful Latter-day Saints about the steps required to reach the celestial kingdom not only in the temple, but after death as well. ${ }^{119}$

\section{The Desert vs. The Garden}

The temple does more than look forward to the end of a mortal journey, however; it looks back to the very origins of the biblical tradition of human experience. The Mormon temple was not only to be the representation of Heaven for those who lived faithfully, but it was recreation of the paradise that existed in the Garden of Eden. The temple-as-Eden, however, is a juxtaposition of the romantic and nostalgic idea of America, the "New World," as a new Eden. Eighteenthcentury author Robert Beverly described the American continent as "so delightful, and desirable; so pleasant, and plentiful... so temperate, sweet, and wholesome; so charming, and fruitful... that Paradice [sic] it self seem'd to be there." 120 The "New World" was seen by America's

119 Saints: The Story of the Church of Jesus Christ in the Latter Days, 453, 584.

${ }^{120}$ As quoted in Leo Marx, The Machine in the Garden (New York: Oxford University Press, 1964), 76. 
colonizing people as a garden of fertility, beauty, and bounty - a land "ripe for cultivation by a civilized race." ${ }^{121}$ For the Latter-day Saints, however, the United States and its inhabitants, from whom they had endured nothing but persecution, did not represent an Eden-like garden; it was the temple that was a refuge from the uncultivated, profane world. Arriving in St. George from Salt Lake City, what one "sees first is the desert, formidable and desolate, relieved only by the sight of St. George and its temple, marking the locus of a fruitful, flowering oasis."122

Laurel B. Andrew points out that the official Church view exaggerates the state of the desert in their mountain home. Through entrenching the myth that Utah was a barren, sterile land, the Latter-day Saint pioneers were able to see all progress upon the land "as evidence of God's favoring the Saints' efforts to make Utah a garden." ${ }^{123}$ Furthermore, as converts from across the world flooded to Utah to cultivate the mountain land scape and dot the land with temples, their efforts were viewed as a fulfillment of Isaiah's prophecy that "the mountain of the Lord's house shall be established in the top of the mountains... and all nations shall flow unto it." 124

The Mormons, like Adam, laboured in the task to till and take care of the land. ${ }^{125}$ The process brought sanctification as the Saints themselves became the plants ripe for cultivation; though they had moved westward, they did not move to the barbarian ways of the wild west. The temples produced in that harsh landscape were not the result of an uncivilized people, but the fruits of a dedicated, sanctified community. Andrew explains that building Zion - as Utah was commonly known to the Saints_preceded the garden-like state: "Only when the soil is tilled,

\footnotetext{
121 Andrew, The Early Temples of the Mormons, 190.

122 Ibid, 190.

${ }^{123}$ Laurel B. Andrew, "The Nineteenth-Century Temple Architecture of the Latter-day Saints," 271.

124 Isaiah 2:2, King James Version.

125 See Genesis 2:15.
} 
towns are founded, and righteousness prevails, only then will the land revert to its state of innocence of the first days. The building up of Zion and, significantly, the erecting of a temple to consecrate the land, must be accomplished first." ${ }^{226}$ By building a temple, not only did the Saints demonstrate their ability to cultivate the land, but the temple was the crowning pinnacle of achievement that allowed the land to gain that Eden-like status. By building massive, immovable temples the Saints furthermore demonstrated the ability to dominate their unforgiving environment, through the help of God; the establishment of permanent architecture reflected the permanency of the Latter-day Saint community in the Mountain West.

\section{Part III: The Cardston Temple}

The first temples built by the Church, from Kirtland to Salt Lake City, were built on designs given to church leaders Joseph Smith and Brigham Young by God. In contrast, the planning stage for a temple in Canada was novel in that it included a competition whereby architects anonymously submitted proposals for the temple design. According to a 1913 article found in the Deseret Semi-Weekly News, published in Utah, fourteen architects and firms were invited to submit proposals. While a comprehensive list does not appear to have been saved, among those invited to the competition were the American architects Pope \& Burton, Watkins \& Birch, Cannon \& Fetzer, Ramm Hansen, Miles E. Miller, Don Carlos Young, J.C. Wood, and Joseph Monson. A sole Canadian architect, Hyrum B. Poulson, was invited. ${ }^{127}$ Only seven proposals were submitted, and the proposed designs were not archived with other known temple

\footnotetext{
126 Andrew, "The Nineteenth-Century Temple Architecture," 169.

127 “Approved Design for Temple in Alberta Province," Deseret Semi-Weekly News, 2 January 1913. In Cardston Alberta Temple: An Historical Record, University of Lethbridge Digitized Collections.
} 
records in Cardston, Lethbridge, or Salt Lake City. Only record of the winning proposal seems to have survived: on 1 January 1913, Hyrum Pope, 33, and Harold Burton, a mere 25, were announced as the architects of the winning design (see fig. 16). ${ }^{128}$

\section{A Temple for Alberta}

The Mormon pioneers first arrived in Western Canada in 1887, led by Charles O. Card for whom the town of Card ston would be named. This expansion was motivated by the 1882 Edmunds Act which threatened fines and jail time for polygamists, and both Mexico and Canada were being explored as potential places to preserve the Mormon matrimonial tradition. ${ }^{129}$ Card, under instruction from higher church leaders, selected 41 families for the journey. Many signed up grudgingly for the trip to the "Land Desolation." ${ }^{130}$ Although most expected the voyage to be but temporary, only ten families followed through with their commitment to the trip when spring arrived. ${ }^{131}$

While preserving plural marriage and escaping incarceration as a result of practicing polygamy may have contributed to the Mormon movement to Alberta, the practice did not become a factor in the settlement's success. ${ }^{132}$ In 1888 John W. Taylor and Francis M. Lyman, members of Church leadership in Salt Lake City, accompanied Card to Ottawa with a petition to

128 Paul L. Anderson, “The Early Twentieth Century Temples,” Dialogue: A Journal of Mormon Thought 14 , no. 1 (1981): 11.

129 V.A. Wood, The Alberta Temple: Centre and Symbol of Faith (Calgary: Detselig Enterprises Ltd, 1989), 6, 10 .

${ }^{130}$ A History of the Mormon Church in Canada, (Lethbridge: The Church of Jesus Christ of Latter-day Saints, 1968), 27.

${ }^{131}$ Keith Shaw, Chief Mountain Country: A History of Cardston and District, Vol 1. (Cardston: Cardston and District Historical Society, n.d.), 173. Accessed 17 April 2019, https://web.archive.org/web/20110516202721/http://www.ourroots.ca/e/page.aspx?id=803665.

132 Rebecca J. Doig and W. Jack Stone, "The Alberta Settlement," in Canadian Mormons: History of the Church of Jesus Christ of Latter-day Saints in Canada, ed. Carma and Roy Prete (Provo: Religious Studies Centre, Brigham Young University, 2017), 56-57. 
obtain permission for the lawful practice of polygamy in Canada. Their request was "firmly refused" by Justice Minister Sir John Thompson and Prime Minister Sir John A. Macdonald. ${ }^{133}$ In 1890, church president Joseph F. Smith, nephew of church founder Joseph Smith, issued The Manifesto and officially renounced the practice of polygamy in the church, with a penalty of excommunication for those who continued to enter polygamous unions. Defending polygamy may have influenced the settlement in Alberta, but it did not determine the decision to stay. Card's attitude toward the "land desolation" was transformed, rather, when he was taught about a prophecy made by Joseph Smith in 1843 that the "nation of Great Britain...would never persecute the Saints as a nation" and that at a future time "we should seek refuge in her dominion."134 The Canadian desolation became that Canadian refuge, and Card was no longer an exile tasked with scouting new land but a pioneer whose mission was to fulfill the prophecy of the prophet. ${ }^{135}$

Brooke Brassard argues in her paper "Prairie School in the Prairies" that the years between 1888 and 1912 were formative years for the Mormon pioneers in Southern Alberta, with architectural decisions reflecting the community's transition from temporary refuge to permanent residence. First, small meetinghouses were built, but by the turn of the century the Alberta Latter-day Saints were building larger, more permanent structures such as the Alberta Tabernacle (see fig. 17). Inspiration for these structures was taken from neighbouring towns, including Lethbridge, where "church architecture typical of the western Canadian frontier" was

\footnotetext{
133 John C. Lehr, "Polygamy, Patrimony, and Prophecy: The Mormon Colonization of Cardston," Dialogue: A Journal of Mormon Thought 21, no. 4 (Winter 1888), 120. For a greater discussion of the encounter between the Mormon leaders and the Canadian Government, as well as the Mormon polygamous experience, see Sarah Carter, The Importance of Being Monogamous: Marriage and Nation Building in Western Canada to 1915 (Edmonton: The University of Alberta Press, 2008), 41-50.

134 Ibid, 118.

135 Ibid.
} 
dominant. ${ }^{136}$ Prior to the building of the temple, Mormon buildings in Alberta were meant to be "inoffensive" and to blend with the surroundings. ${ }^{137}$ The Cardston temple, however, broke from the architectural styles of previous buildings, marking the permanence of the Mormon settlement in the Alberta grasslands. The monolithic structure served as a form of permission for the generation of Latter-day Saints that had grown up in Canada to become truly Canadian; their future was in the Mormon towns of Alberta, not in Utah.

Plans to build a temple in Canada were announced by church president Joseph F. Smith in the semi-annual general conference of the Church on October 4, 1912. It had been more than 35 years since Brigham Young announced in 1875 his decision to build a temple in Manti; no other church leader had yet initiated the building of new temples since Young's death. Mormon temples had already established a traditional location on a hill as a way to fulfill the previouslycited Old Testament prophecy found in Isaiah 2:2: "In the last days, the mountain of the Lord's temple will be established as chief among the mountains; it will be raised above the hills, and all nations will stream to it," although there is no doubt that find ing a hill in the prairies presented somewhat of a challenge. Two areas were considered: a small hill in Raymond, proposed by the Taylor Stake, and another site in Cardston, favoured by members of the original Alberta Stake established when Mormon pioneers settled in the area. ${ }^{138}$ The Cardston site, situated on Lee Creek, was chosen later in the year, fulfilling a prophecy made by John W. Taylor on October 8 , 1888 that the specific location would house a temple in the coming years. ${ }^{139}$

${ }^{136}$ Brassard, "Prairie School in the Prairie," 143.

137 Ibid, 148.

${ }^{138}$ A Stake in the Church of Jesus Christ of Latter-day Sa ints is a group of wards—or congregations — similar to a Catholic diocese.

${ }^{139}$ A History of the Mormon Church in Canada, 72. See also Doig and Stone, Canadian Mormons, 63. 
The temple site alongside Lee Creek was dedicated by Joseph F. Smith on July 27, 1913 in a day that Edward J. Wood, Alberta Stake president, described as "the great day for Canada; the greatest day in our history!"'140 Many church leaders gave inspirational sermons, and the thousands congregated on the hill sang hymns including "O Ye Mountains High," written by Charles Penrose of the First Presidency of the Church who was present at the site dedication. Ground-breaking for the building occurred later that year on November 5, $1913 .{ }^{141}$

September 12, 1915: "We received word this week that our corner stone would be laid next Sunday_ but not until Saturday night did we know that Brother Mackay [sic] would officiate. It was good news to us." ${ }^{42}$ By September 1915, the foundation of the temple had been constructed (see fig. 18). A metal exoskeleton had been raised, and the cornerstone was laid on Sunday, September 19 in a ceremony led by apostle David O. McKay. Edward J. Wood's journal retells the events of the day:

"It had rained nearly all night and was very muddy in the morning, but it didn't dampen our spirits at all and nearly 2000 people gathered in the tabernacle where we marched in order according to our position and priesthood to the Temple square — headed by Bro. Mackay and took up our positions on a platform erected around the S.E. corner where the stone was ready to set and the following programs of a most memorable event in our history... it rained and hailed-but it didn't matter at all. "143

Like the site dedication, there was much singing, praying, and preaching. A financial statement was given: $\$ 127,450$ had been spent. The granite stone was placed in front of a copper box — a time capsule — containing a brief history of Card ston and the temple there, a copy of the

\footnotetext{
${ }^{140}$ Edward J. Wood Diary, “Sun. July 29, 1913,” in Edward J. Wood collection, 1884-1982; Journals, 1912 January-1915 December. Church History Library, MS 7313. Emphasis original.

${ }^{141}$ A History of the Mormon Church in Canada, 72.

142 Edward J. Wood Diary, "September 12, 1915."

143 Ibid.
} 
Lethbridge Herald, and lists of church leaders at the time. ${ }^{144}$ The capstone ceremony would occur two years later as the last of the granite was put into place on the temple's exterior (see fig. 19).

The building of the temple was not without its share of tragedy. On December 18, 1920, Rudolph Herr died from injuries sustained six weeks prior when he fell through some wood scaffolding and into the baptistry, breaking an arm and a leg and fracturing his skull. In one touching note written about the end of his life, Herr had, only minutes before his death, been reported "fine" by nurses who had overheard him singing a hymn. "The hymn was Oh My Father," the account remembers - the same hymn that had been instrumental in his conversion as Mormon missionaries sang it on the street of Copenhagen twenty years earlier. ${ }^{145}$

Three years later, the temple was dedicated on August 26, 1923. It was the first temple built after Utah's admission as a state to the United States of America and there are two significant ways that the Card ston temple represents a shift in the message behind the architectural design. First, it was a conscious diversion to American modernity. Second, it moved away from the defensive undertones found in the architecture of the Pioneer temples and symbolized the Mormon re-integration into American culture and society.

\section{Moving to Modernity: The Cardston Temple and Frank Lloyd Wright's Unity Temple}

The Card ston temple was the first significant Modern building in Alberta and was a significant move to Modern architecture in the Mormon church. ${ }^{146}$ Only one Prairie school style structure predates the Cardston temple in Western Canada; Frank Lloyd Wright's Banff Pavilion

144 Ibid.

145 "Rudolf Herr's story as told by his granddaughter Elayne Fitzner and grandson John Hollingsworth," Cardston Historical Society Digital Archive, PH 8133, Box 1, fd. 2, no. 24-26. Accessed January 27, 2020.

146 Trevor Boddy described the Cardston temple as the "first consciously Modern" major building in the history of Alberta architecture." See Boddy, 33. 
was begun in 1911 and does not appear to have influenced the Cardston temple design ${ }^{147}$

Wright's Prairie school style, nonetheless, had a profound effect on the design of the Cardston temple, and Unity Temple — one of Wright's few religious commissions — has many points of comparison to the Cardston temple. Unity Temple may have been viewed by Hyrum Pope in the early twentieth century as he worked in Chicago, perhaps with Louis Sullivan. ${ }^{148}$

Unity Temple was built between 1905 and 1908 in Oak Park, a suburb of Chicago, Illinois. Designed by Frank Lloyd Wright as a worship hall for a local Unitarian congregation after the previous building had been destroyed by fire, the church strayed drastically from previous forms of religious architecture. Wright had little experience in ecclesiastical design, but came from a family of Unitarian thinkers; the Unitarian community in Oak Park had already voiced opposition to Gothic architecture for its association with Catholicism and the Trinity, and Wright was awarded the commission with the intention of separating from all preconceived notions of church architecture. ${ }^{149}$ Wright's concrete construction reflects the community's need of a church building from which they could expect endurance and permanence and was praised for embodying the principles of the Unitarian faith. ${ }^{150}$ Significant emphasis was placed upon the fact that the entire structure was one monolithic piece of concrete-one rock; the church,

147 The Banff Pavilion was a gathering space in Banff National Park, more than $350 \mathrm{~km}$ from Cardston, and it is unlikely that the architects, in Salt Lake City, would have known about the construction of the building Canada.

148 Personal correspondence with Michael Gibb, 22 January 2019. It is Mr. Gibb's belief that Pope worked with Sullivan, although no definitive evidence of this is available. A 1998 pamphlet in an archival file at the University of Utah claims that Pope studied at the Art Institute of Chicago before opening his office in Salt Lake City with Harold Burton "c. 1906." See "Highland Park Historic District," Utah National Register Collection (Utah Division of State History, 1998), 17. Archived in the collections of the University of Utah and availa ble online at https://collections.lib.utah.edu/ark:/87278/s6t47gwf.

${ }^{149}$ Candace Jones and Felipe G. Massa, "From Novel Practice to Consecrated Exemplar: Unity Temple as a Case of InstitutionalEvangelizing," Organization Studies 34, no. 8 (2013), 1115-1117.

150 Joseph Siry, Unity Temple: Frank Lloyd Wright and Architecture for Liberal Religion (Cambridge: Cambridge University Press, 1996), 196. 
physically and theologically, was not only built upon a strong foundation but it was the strong foundation. ${ }^{151}$

The Card ston temple's archival file notes that Pope, who had studied in Chicago in the first decade of the twentieth century, had been influenced by Frank Lloyd Wright, and Laurel B. Andrew points out that Pope's design for the Cardston temple bears a striking resemblance to Wright's Unity Temple though provides no further analysis. ${ }^{152}$ While there is no concrete evidence that Pope worked with the famous architect, the Cardston temple was not the first building designed by Pope and Burton that bore resemblance to Unity Temple - the chapel for the Latter-day Saint Salt Lake First Ward, built in 1910 in Salt Lake City adopts an elongated basilica floorplan but its exterior bears a striking resemblance to Unity Temple in its modular, geometric segments and concrete piers to hold up a cornice above the window (see fig. 20). Building on the precedence of this chapel, many features of the Cardston temple appear to have been drawn from architectural details of Unity Temple.

The Card ston temple was first influenced by the Oak Park church not in style but in material. Each building was constructed of reinforced concrete; like Unity Temple, the Cardston temple was the strong foundation of faith for Latter-day Saints. By focusing their lives on being worthy to attend the temple, members of the church could feel confident that their actions were aligned with God's will. Both buildings make use of geometric post-and-lintel decoration on the

151 Ibid, 199.

152 See "The Alberta Temple: Fact Sheet." Book 3, page 13, in Cardston Alberta Temple: An Historical Record, University of Lethbridge Digitized Collections. This archival file mentions that Pope had been influenced by Frank Lloyd Wright. Jacqueline Hucker, working for Parks Canada, made a brief connection to Unity Temple, although no analysis was given. See "The Cardston Temple, Alberta, and Nonconformist Form," Journal of the Society for the Study of Architecture in Canada 23, no.2 (1998): 55. Hucker's noting of the connection seems to have come from her reading of Laurel B. Andrew's The Early Temples of the Mormons, 24, which she frequently cites in her report for the Historic Sites and Monuments Board of Canada (1992). Trevor Boddy, in his Modern Architecture in Alberta, also seems to use Andrew as a resource. See Trevor Boddy, Modern Architecture in Alberta (Regina: Canadian Plains Research Centre, 1988), 34. 
face of clerestory windows, a Byzantine-inspired cross-in-square floorplan, and corner stairwells - although the corner stairwells in Cardston are offset and angled slightly rather than flush with the building's perimeter as in Wright's design (see figs. 21 and 22). It is perhaps only chance that Pope and Burton drew inspiration from a Unitarian church aiming to separate itself from previous Christian architecture, for Unitarianism is one of the only Christian denominations that, like Mormonism, is distinguished from traditional Christianity by its rejection of the doctrine of the Trinity, and, like Mormonism, has sought distinction from their neighbours through architecture.

The ornate details of the piers surround ing the windows in the Cardston temple also bear similarity to the concrete decoration on the piers of Unity Temple's clerestory (see figs. 23 and 24). Trevor Boddy in his Modern Architecture in Alberta notes that the Cardston temple has adopted its "chevron motif and window surrounds from the Unity Temple." 153 As no zig-zag chevron exists in the temple design, one must assume that by "chevron motif" Boddy is referring to the delicate pattern on the geometric post-and-lintel façade of each side of the temple. Four years after Boddy's publication, a brief entry on the Cardston temple in A Guide to Canadian Architectural Styles also made reference to the "chevron motifs and the grid pattern of the window mullions" in connection to Wrightian characteristics. ${ }^{154}$ These piers are in both buildings set in front of recessed clerestory windows and support an overhanging cornice. ${ }^{155}$ While the piers are significantly elongated in the Cardston temple, in both buildings there is a hexapartite division and piers that extend only partly down the side of the structure. The Cardston temple was the first Latter-day Saint structure to bear these square post-and-lintel piers, although they

153 Boddy, Modern Architecture in Alberta, 35.

${ }^{154}$ Leslie Maitland, Jacqueline Hucker, and Shannon Rickets, A Guide to Canadian Architectural Styles (Peterborough: Broadview Press, 1992), 177.

${ }^{155}$ Paul L. Anderson, "The Early Twentieth Century Temples," Dialogue 14, no. 1 (Spring 1981), 13. 
have been adapted into many later twenty-first century temple designs. ${ }^{156}$ The Cardston temple further uses the piers to emphasize its verticality as they extend, unlike those at the Oak Park building, along a two-story division. The piers are also each connected with artificial ground levels. As can be seen in preliminary sketches for Unity Temple, plant life was intended to sprout organically from the artificial floor at the base of the columns; the ground was also raised artificially surrounding the Cardston temple and a planted terrace artificially raised the height of the hill (see figs. 25 and 26).

The heavy, geometric exterior structures of Pope's temple in Cardston and Wright's temple in Oak Park bear many other similarities. Both buildings have a flattened roof leading to a square pyramidal peak set within the middle of an otherwise flat roof, although Pope's design strays from that of Wright in the Cardston temple's vertical elevation as additional levels are added to form the more prominent apex (see figs. 27 and 28). Perhaps most notably, as it breaks from tradition in both faiths, is the lack of spires. Unitarian doctrine proclaims that "God is present, residing in human community," and Frank Lloyd Wright is noted to have taught the congregation at Unity Temple that "God should not be sought in the sky, but on earth." 157 A spire in Christian architecture points heavenward and reaches great heights to link the earth with the heavens. Yet following the same logic used by Wright, the Card ston temple was too notably absent of spires despite such towers being present on all earlier Latter-day Saint temples. In Latter-day Saint theology, the temple is the House of God, and, parallel to Wright's teachings, God can be sought in the temple rather than in the sky.

\footnotetext{
156 The post-and-lintel pattern was continued, for example, in the Draper Utah and Calgary Alberta temples of the twenty-first century.

157 Candace Jones and Felipe G. Massa, "From Novel Practice to Consecrated Exemplar: Unity Temple as a Case of Institutional Evangelizing," 1111.
} 
Wright's Byzantine cross-in-square plan of Unity Temple is also reflected in the Cardston temple's architecture, described in an archival letter as an "octagonal shape, similar to a Maltese cross." ${ }^{158}$ This shape, likely for both Wright and Pope, was a way to demonstrate a purer form of Christianity, as it hearkened back to the early Christian church and Byzantine architecture. While the interior separation of space in the Cardston temple is drastically different than the open worship hall of Unity Temple, or a Byzantine example such as the Hagia Sophia, Pope and Burton's design does make use of the Early Christian basilica atrium. Latter-day Saint commentary has used this courtyard to link the Cardston temple to Solomon's temple, explaining that the space was a courtyard akin to the Court of the Gentiles of the Biblical temple (see fig. 29). ${ }^{159}$ This connection is not wholly unfounded, however, the atrium outside the Cardston temple served a purpose more aligned with the early Byzantine atrium—not as a space for those who would not, or could not, enter the temple, like the Court of the Gentiles, but as a space where the worshipper could prepare to enter the sacred space and to create a distinct transition from the profane world to the spiritual realm.

Finally, the Cardston temple and Unity Temple are each made of reinforced concrete construction; the Cardston temple was one of the first buildings in Canada to use this construction technique, and Unity Temple was the first church to do so. ${ }^{160}$ Like Brigham Young's desire to have a permanent temple structure in the Salt Lake Valley, the concrete construction of the Cardston temple lends itself to the idea that it was intended to be an

158 "The Alberta Temple Fact Sheet," 12. The description of "Maltese cross" was immediately a ssociated with the shape of the temple, for it is described as such in Edward J. Wood's journal in an entry on November 9, 1913, four days a fter the ground breaking of the temple See Edward J. Wood collection, 1884-1982; Journals, 1912 January-1915 December; Church History Library. The term was further used Joseph Y. Card's 1923 publication in the Improvement Era in which he described the shape of the temple as an "octagonal shape or a Maltese Crown ground-plan." See Joseph Y. Card, “The Cardston Temple,” The Improvement Era 26, no. 11 (September 1923), 1003.

159 “Great Mormon Temple At Cardston,” Calgary Herald (Sat, Jul 9, 1921), 21.

160 Jones and Massa, 1100. 
immovable, permanent feature of the landscape; the Unitarian congregation of Oak Park likewise sought an indestructible edifice after the previous church had been damaged by fire. Concrete construction is hard, unchanging, and resistant to damage by fire and weather, and in 1913 served as a perfect metaphor for the faith of the Mormon pioneers who had settled in Southern Alberta and were now a permanent feature in the landscape, resistant to the persecution the faith had suffered for decades across the United States. While Unity Temple promoted a look of exposed concrete, however, the concrete of the Cardston temple was encased in three feet of white granite, quarried from a site near Nelson, British Columbia, nearly 500 kilometers away. ${ }^{161}$ An explanation for this difference is found in examining each church's budget; in Oak Park, Wright used concrete partly due to its low cost while working with limited funding. ${ }^{162}$ As we will see in the following section the Mormon church heeded to no such restrictions and it is believed that the granite alone exceeded a cost of $\$ 300,000$ and required approximately 300 rail cars to transport to Cardston. ${ }^{163}$

Despite the strong influence of Unity Temple on the Card ston temple design, public literature within the Church of Jesus Christ of Latter-day Saints has historically focused rather on how the Cardston temple compared to a very different architectural precedent: the Aztec temples of Mesoamerica. ${ }^{164}$ Ironically, for Church membership in the early twentieth century it was not modern American architecture they were replicating, but ancient American architecture. Numerous reports promote the brief connection between the Cardston temple and ancient Aztec

161 "Talk in Stake General Priesthood," Jan 21, 2001, Cardston Historical Society Digital Archive, PH 8133, Box 1, fd. 2, no. 20-22. Accessed January 27,2020.

162 Jones and Massa, 1112.

163 "Talk in Stake General Priesthood," Cardston Historical Society Digital Archive.

164 Paul L. Anderson, "First of the Modern Temples," Ensign, July 1977. 
temples. ${ }^{165}$ Granted, the stepped pyramidal structure in Canada is reminiscent of the ancient stone structures which were intended to elevate the sacrifices of the faithful to a deity. Yet the Cardston temple officiates in no public displays of faith atop its pyramidal peak; all ritual takes place behind closed doors within the shelter of the building. The focus was more importantly on the connection between the ancient Mesoamericans and the Book of Mormon, which claims to chronicle the history of ancient inhabitants of the American continents. ${ }^{166}$ Members of the Church have been consistently taught that the great civilizations in the Americas, such as the Mayans, were among the descendants of Book of Mormon peoples. ${ }^{167}$ The introduction of the Book of Mormon still reads, in outdated verbiage, that the individuals of whom the Book of Mormon record speaks "are among the ancestors of the American Indians." 168 As the Church of Jesus Christ of Latter-day Saints and its offshoots are the sole sects of Christianity to lay claim to the Book of Mormon, connecting the Church with the ancient people about whom their unique book of scripture is written is an important factor in differentiating from mainstream Christianity.

\section{Costs of the Cardston Temple}

As early as 1913 it was understood that the temple in Cardston would increase the value of land in the town for both Mormons and non-Mormons alike. An advertisement run in the Winnipeg Tribune announced several lots for sale "within four blocks from the temple site at

\footnotetext{
165 “Great Mormon Temple At Cardston," Calgary Herald (Sat, Jul 9, 1921), 21. See a lso "Marble and Lumber From Lands Remote Used by Mormons for Cardston Temple," The Vancouver Sun (Sun, Jul 3, 1921), 7, and “A Mormon Temple In Alberta Town," Leader-Telegram (Wed, Dec 17, 1919), 8.

166 The Book of Mormon is part of the Latter-day Saint scriptural canon, which includes both the Old and New Testaments in addition to the Book of Mormon, a text translated by the Church's founder Joseph Smith, and the Doctrine and Covenants, a compilation of revelations received shortly after the establishment of the Church.

Members of the Church were sometimes called "Mormons" in the mid-nineteenth century as a result of this text. 167 Journal of Discourses, 25:123-124.

168 "Introduction," The Book of Mormon: Another Testament of Jesus Christ (Salt Lake City: The Church of Jesus Christ of Latter-day Saints, 2013).
} 
$\$ 100$ each. They will not last long at this price." ${ }^{169}$ Yet, although nearly 7000 Mormons had congregated in Southern Alberta in the quarter of a century since Card brought the first Mormons to Western Canada, the building of such a massive structure was not possible through the meagre financial means of the Canadian Saints. ${ }^{170}$ Much of the funding came from Church headquarters, collected from tithing across the continent. The Salt Lake Telegram explains, however, that "many thousand dollars were contributed by members of the church in Canada," and "much of the rough labor on the temple was contributed by members without pay." 171

While Church archives have few publicly accessible records about the building of the Cardston temple, there are ample newspaper reports that provide generous insight to the costs associated with construction of the temple. Throughout the early 1920s, newspapers around the continent published notices of its approaching or recent completion, sharing a few sentences or sometimes multi-page spreads about the history and beliefs of the Mormon people. The media pegged the temple by some as "odd" and by others as "remarkable," while another claimed that the Cardston temple would "surpass in beauty the church in Salt Lake City." 172

It is unclear what the budget for the temple originally might have been, if such a budget existed at all. When the announcement was made that a temple would be built in Canada, the proposal from the architects is reported to have anticipated a modest cost of a mere $\$ 100,000$, and the Deseret Evening News placed the time of construction as "about one year." 173 Both of these original figures increased tenfold. When construction began, it was quickly evident that

169 “A Quarter of a Million Dollars,” The Winnipeg Tribune (Sat, May 31, 1913), 12.

170 V.A. Wood, The Mormon Temple (Calgary: Detselig Enterprises Limited, 1989), 19.

171 "Great Mormon Temple Constructed At Outlay of $\$ 1,250,000$ in City of Cardston Is Nearing Completion," Salt Lake Telegram (Sun, Oct 24, 1920), 2.

172 “A Mormon Temple In Alberta Town," Leader-Telegram (Wed, Dec 17, 1919), 8.

173 "Mormon Temple for Alberta," Chippewa Harald-Telegram (Sun, Feb 23, 1913), 12. This number was reiterated in "Site for Temple," Deseret Evening News (28 July 1913), 2 and in the "Passing News" section of the Improvement Era 16, no. 5 (March 1913), 524. 
such a low figure was unachievable; newspapers later in the year published estimated costs of $\$ 250,000$, though even that figure increased exponentially throughout the next decade. ${ }^{174}$ By 1914 , the estimate had increased to $\$ 300,000$ in one report and $\$ 400,000$ in another. ${ }^{175}$ In 1919 , $\$ 125,000$ had been spent on the structure, and The Transcript Bulletin, a Utah paper, provided an updated budget of about $\$ 600,000$ for the total price. ${ }^{176}$ By 1922 , the Calgary Herald reported the cost of construction having reached $\$ 720,000 .{ }^{177}$ The Vernal Express, just prior to the dedication in 1923, wrote that the cost had been "about $\$ 750,000$," though compared to other sources that was a very modest estimate indeed. ${ }^{178}$ The Morning Register of Eugene, Oregon, reported that the cost was "in the neighbourhood of $\$ 1,000,000$," a figure corroborated by the Vancouver Sun and the Leader Telegram. ${ }^{179}$ The one million dollar mark was also listed in both 1920 and 1922 editions of Popular Mechanics, a periodical that also claimed the decoration in the Celestial Room alone had "amounted to nearly $\$ 100,000 . " 180$ The highest budget, published three years before the temple was completed, was printed in Salt Lake City as $\$ 1,250,000 .{ }^{181}$ In contrast, a Presbyterian church was built in Cardston in 1921 for a total cost of $\$ 17,000{ }^{182}$

While it is certain that the numeric figure of the temple's cost increased over the course of a decade due to inflation, the upward trend demonstrates the desire to complete every aspect

\footnotetext{
174 "Mormons in Canada," The Windsor Star (Wed, Dec 10, 1913), 7. See also "A Quarter of a Million Dollars," The Winnipeg Tribune (Sat, May 31,1913), 12.

175 "Mormon Temple in Canada First On British Soil," The Daily Republican (Mon, Jun 1, 1914), 3. See also

Calgary Herald (Thu, Jan 15, 1914), 7.

176 "Seventh Temple of Mormon Church Dedicated," The Ogden Standard (Thu, Sep 23, 1915), 6, and The

Transcript Bulletin (Fri, June 6, 1919), 7

177 “Cardston Temple," Calgary Herald (Fri, Aug 4, 1922), 19.

178 "Cardston Temple to Be Dedicated August 26," Vernal Express (Fri, Aug 3, 1923).

179 "Huge Temple Dedicated," Morning Register (Sun, Sep 2, 1923), 15. See also "Marble and Lumber From

Lands Remote Used by Mormons for Cardston Temple," The Vancouver Sun (Sun, Jul 3, 1921), 7, and “A Mormon

Temple In Alberta Town," Leader-Telegram (Wed, Dec 17, 1919), 8.

180 "Mormons Build Odd Temple in Canadian Town," Popular Mechanics vol. 34 (Jul - Dec 1920), 180, and

"Mormon Temple is Designed on Straight Lines," Popular Mechanics vol. 37.3 (March 1922), 333.

181 "Great Mormon Temple Constructed At Outlay of $\$ 1,250,000$ in City of Cardston Is Nearing Completion,"

Salt Lake Telegram (Sun, Oct 24, 1920), 2.

182 “Cardston Temple," Calgary Herald (Fri, Aug 4, 1922), 19.
} 
of the temple with the finest material. Fewer reports exist as to the costs associated with the interior decoration of the temple, though the Buffalo Courier, published in Buffalo, New York, reports the following numbers: the rug on the Celestial room floor "alone cost more than $\$ 7000$ " and a power plant was built on-site to heat the temple at a cost of $\$ 69,000 .{ }^{183}$ Chandeliers reported to be of pure bronze were placed throughout the temple, while marble was imported from Italy, Tennessee, Ohio, and Ontario and the paper exclaimed that "the question of expense was simply not considered." ${ }^{184}$ Over $\$ 10,000$ of gold was used in the decoration according to a Wisconsin paper. ${ }^{185}$ Joseph Young Card, the son of Cardston's founder Ora Card, provided the most extensive report from inside the Church: "baths and toilets are of white marble trimmed with nickel and silver;" "interior electric wiring, only $\$ 8,085$," "roofing of apex, $\$ 13,000$; skylights of prismatic glass $\$ 19,111 . "{ }^{\prime 186}$ Card's report breaks down the total cost as one million dollars for the structure itself and another $\$ 100,000$ for the interior furnishings. ${ }^{187}$ While the construction was completed in 1921, the temple was not yet furnished due to a lack of fundspresumably, that final $\$ 100,000$. According to one oral tradition, Stake President E.J. Wood announced to the architects Pope and Burton that he would soon take a trip to Utah and purchase manufactured furniture for the temple. In an offer that would have been typical of Frank Lloyd Wright, the architects proposed that they custom design the furniture to match the aura of the building they had laboriously designed - free of charge. It seems they were taken up on their offer. $^{188}$

183 "Million Dollar Mormon Temple Dedicated in Canada Today," Buffalo Courier (Sun, Aug 26, 1923), 29. ${ }^{184}$ Ibid.

185 “A Mormon Temple In Alberta Town," Leader-Telegram (Wed, Dec 17, 1919), 8.

186 J.Y. Card, "Alberta Temple is Masterpiece of Construction and Finish," Lethbridge Herald (Aug 28, 1923). Also a vailable from Cardston Alberta Temple: An Historical Record, Digital Archive, University of Lethbridge.

187 Card, "Alberta Temple is Masterpiece of Construction and Finish."

188 Personal correspondence with Michael Gibb, 22 January 2019. Gibb was the lea ding architect of the renovation of the Cardston temple in the 1990s. Another version of the story is recounted in Wood, The Alberta Temple, 57. 
Although the temple was the first begun outside of Utah, it was not the first to be completed. On October 3, 1915, the Church announced its intention to build a temple in the Sand wich Islands. The selected site was in Laie, on the north shore of Oahu, Hawaii. The Laie temple, also designed by Pope and Burton, was a much smaller version of the Cardston temple, at only 42,000 square feet compared to the Cardston's nearly 90,000. The Laie temple was dedicated in 1919 - though the relatively quick construction time was partly due to the fact that, unlike in the Rocky Mountains, construction could be done year-round - and is reported to have cost only $\$ 200,000 .{ }^{189}$ While the cost of the Cardston temple seems astronomical compared to the cost of the smaller structure in Hawaii, the price tag pales in comparison to what the Church had spent on the Pioneer temples: the Daily Republican, a Pennsylvania paper, listed the prices for the Salt Lake City temple at a shocking $\$ 4,000,000$, while the St. George, Manti, and Logan temples cost each $\$ 3,000,000 .{ }^{190}$ These costs were elevated due to lack of railway and the cost of transporting materials to Utah, though the St. George, Manti, and Logan temples were each approximately 100,000 square feet—comparable to Cardston—while the Salt Lake City temple was easily the largest, doubling the other Pioneer temples at over 200,000 square feet.

Prior to the temple's dedication, while furniture was being completed, an open house was held. As is custom today, members of the public were invited to tour the interior of the building prior to its dedication, after which point the building would be accessible only to members of the Church with temple recommends. Although there was no fee to enter the temple, the town of Cardston certainly did not waste an opportunity to profit from those who wished to see it. A 1923 ad in the Lethbridge Herald described the temple as "one of the greatest architectural achievements on the continent," and reminded potential visitors that "this will be the last year of

189 The Transcript Bulletin (Fri, June 6, 1919), 7.

190 “Mormon Temple in Canada First On British Soil," The Daily Republican (Mon, Jun 1, 1914), 3. 
the edifice being open to the public for inspection." 191 Special campsites were reserved for tourists and the ad reminded potential visitors that Cardston was "a nice motor drive from Waterton Lakes." 192 The advertisement was not printed for lack of prior tourists, however, as over 10,000 people are reported to have visited the site in 1922 alone. ${ }^{193}$ In total, over 50,000 tourists visited the temple prior to its dedication, with special trains being arranged to bring the onlookers into Cardston. ${ }^{194}$

\section{Architectural Creation of Sacred Space in the Early Temples}

The early temples of the Church of Jesus Christ of Latter-day Saints used architecture to facilitate ritual ceremony and to enhance the symbolic experience for temple patrons. The first division of space is the separation of the temple proper from the annex - a space where the entrance hall, offices, laundry, clothing rental, and often changing rooms were located. This intermediary space provided room for temple administrative tasks that were not part of the temple ceremony. Upon entering the main temple structure for ordinance work, the building itself was broken up in a series of rooms designed to assist the temple patron in better understanding the symbolic nature of their temple ordinances.

Prior to performing an endowment ceremony on behalf of a deceased ancestor is the ritual of proxy baptism, referred to colloquially as 'baptisms for the dead.' These baptisms are performed only for those who were never baptised into the Church during their life and occur in the basement of early Latter-day Saint temples in a font resting upon the back of twelve oxen. The baptismal font draws from the imagery of the brazen sea that stood outside of Solomon's

\footnotetext{
191 "Cardston: The Temple City," The Lethbridge Herald (Thu, Jun 7, 1923), 5.

192 Ibid.

193 “Cardston Temple," Calgary Herald (Fri, Aug 4, 1922), 19.

194 A History of the Mormon Church in Canada, 73-74.
} 
Temple, where three oxen faced each of the four cardinal directions. ${ }^{195}$ In Solomon's Temple, the sea was "set above upon [the oxen], and all their hinder parts were inward." 196 Such configuration has always been associated with Latter-day Saint Temple baptismal fonts (see fig. 30). Additionally, the Latter-day Saint faith associates the twelve oxen with the twelve tribes of Israel, with baptism as a symbol of being "gathered" to the house of Israel. ${ }^{197}$ The baptism is performed by full immersion and is placed in the basement due to its association with death and subsequent burial in the earth, followed by a new birth as the individual is raised from the water. The person for whom the baptism has been performed (a living person's baptism is never performed in a temple, but generally in a baptismal font in a Church meetinghouse) is now received into the covenant and has been spiritually reborn, symbolically resurrecting from the grave below the ground. The individual is now prepared to embark on their journey of climbing toward the presence of God, symbolically located at the top of the temple structure.

The baptismal font in the Cardston temple is unique in its location above ground. Though placed in the basement, the baptismal font is placed at a higher elevation than the entry level to the temple. A conversation with Michael Gibb, the leading architect of the 1990s restoration and renovation in the temple, explained that Pope and Burton had built a retaining wall and terrace around the temple, artificially raising the "ground" level surrounding the building. The terrace had been open to the public and accessible from staircases in the courtyard. Since the terrace had

\footnotetext{
195 Jeff Lindsay, "The Yoke of Christ: A Light Burden Heavy With Meaning," Interpreter: A Journal of Mormon Scripture 18 (2016), 185, 201.

1961 Kings 7:5 (King James Version).

197 For a discussion on the Latter-day Saint understanding of the scattering and gathering of the twelve tribes of Israel, see Joseph Fielding McConkie, "The Gathering of Israel," in Religious Educator 11, no. 1 (2010), 46-62. On page 54, McConkie explains that "in ancient times, when Isra el turned from Christ and broke her covenants, she lost the right to a land of inheritance, it being a seal or token of the covenant; she was then scattered among the nations of the earth. Prophecy repeatedly foretold that Israel would be scattered among all the nations of the earth, and that scattering continues to this day. We as a Church have been commissioned to gather scattered Israel, which we do by sending out missionaries to declare Christ and to invite all who believe to be baptized."
} 
been planted with trees, it had been considered ground level—and the baptismal font was placed deep below. In the 1960s, however, the space was renovated, and the terrace was replaced with office and administrative space (see fig. 31). ${ }^{198}$ With the removal of Pope and Burton's artificial ground, the baptismal font is now above grade. ${ }^{199}$

Following baptism is the end owment ceremony, which presents the individual with a reenactment of the history of the creation of the world and of Adam and Eve that is spread across multiple rooms, each with a specific purpose in the ceremony (see fig. 32). The endowment begins in the Creation room, a space decorated with murals illustrating the six days of creation. The patrons are ushered next to the Garden room, where murals depict a lush and paradisaical garden (see fig. 33). Following Adam and Eve as they are expelled from the Garden, the group is escorted to the Telestial room, often known as the World room, where Adam and Eve learn about the struggles of mortal life. The harsh realities of a world infused with death and evil are portrayed in the World room, with murals that include a growling leopard, a fox and a wolf ready to "devour a young lamb, an eagle in descent with outstretched talons, and a mountain deer calling for its lost mate" (see fig. 34). ${ }^{200}$ The aggression displayed in the World room that parallels the aggression that opposes God's people in a fallen and sinful world. As the ceremony administers covenants with God that prepare and enable both Adam and Eve, and in turn the temple patrons, to return to the presence of God, the ceremony proceeds to the Terrestrial or veil room. In the Cardston temple, smaller panels that depict scenes from the life of Jesus Christ adorn this second-to-last stop of the ceremony, which represents the "world during the Millennial

\footnotetext{
198 “Renovation Completed at Alberta Temple,” Church News (July 8, 1961).

199 Personal correspondence with Michael Gibb, 22 January 2019.

200 Wood, The Alberta Temple, 54.
} 
period." 201 It is a room of relative "peace and order when contrasted with the telestial or world room." 202

At the conclusion of the ceremony, the party is admitted into the Celestial room. It is when one passes through a veil between the Terrestrial room and the Celestial room that the patron is introduced to the ideological presence of God; the Celestial room might be equated with the Holy of Holies in Solomon's temple, which is separated from the Holy Place by a veil and represents the presence of God. ${ }^{203}$ The endowment ceremony is thus a continual cycle from the fall of man, prior to which Adam and Eve had walked with God in the Garden of Eden, to their reunification with the Lord following their resurrection. Latter-day Saint doctrine teaches that individuals lived with God prior to earth life, and the temple endowment for Church members today embodies the cycle of God's children coming to earth, and, if trials and tribulations are properly endured, returning to live with God after death. ${ }^{204}$

The architectural layout of a space contributes to its sense of sacredness by following previously established patterns of sacred space. Just as the Stations of the Cross in a Catholic church move in a clockwise direction, so too do the progressive rooms of the endowment ceremony in early temples usher worshippers in a clockwise direction from room to room. ${ }^{205}$ Each room of the endowment ceremony is a few steps higher than the previous, creating a clear vertical ascension to the presence of God in the celestial room. In the Manti temple, for example,

\footnotetext{
201 Ibid, 56.

202 Ibid.

${ }^{203}$ For a more complete comparison between Latter-day Sa int temples and Solomon's temple, see David Seely, Solomon's Temple (London: Thames \& Hudson Ltd, 2007), 191-193.

204 “Our Premortal Life," Chapter 6 in Doctrines of the Gospel Student Manual (Salt Lake City: The Church of Jesus Christ of Latter-day Saints, 2010). Manualavailable online at

https://www.churchofjesuschrist.org/study/manual/doctrines-of-the-gospel-student-manual/6-premortallife?lang=eng.

${ }^{205}$ Richard Kieckhefer, "Architectural Expression and Ways of Being Religious," In The Oxford Handbook of Religion and the Arts, ed. Frank Burch Brown (Oxford: Oxford University Press, 2014): 206.
} 
the Creation and Garden rooms are in the basement, while the following three rooms are on the second story; the three latter rooms are separated by steps or a ramp as the patron ascends to the heavenly level where they will enter into the presence of God. Each room takes up roughly a quarter of the rectangular floorplan, and the Celestial room is in the northeast corner of the building (refer again to fig. 2).

The Cardston temple's interior floor plan was most significantly set apart from the Pioneer temples by a few factors. First, the assembly hall that had filled the top floor of the Pioneer temples had been removed. In Utah, the chamber was used as a meeting space for the Church's top leaders, and presumably the space was deemed unnecessary in Canada. None of the following temples would be built with an assembly hall, making the Celestial room truly the highest part of the building. The second change, however, was to the placement of the Celestial room altogether. Unlike the rectangular plans of the Pioneer temples, where the Celestial room was placed in a corner, in the Cardston temple the Celestial room was moved to the very centre of the building (refer again to fig. 32). This assignment truly places the Celestial kingdom, symbolized by the Celestial room, in the centre of the Mormon mind set; as the faithful templegoer circles through life, they are instructed to keep the goal of returning to live with God at the forefront of their priorities. A common Latter-day Saint hymn vocalizes the prayer "lead me, guide me, walk beside me; help me find the way. Teach me all that I must do to live with Him some day." 206 By remaining temple worthy and frequently entering into the symbolic presence of God in the Celestial room, members of the Church can know they are on the path to return literally to the presence of God.

206 "I Am a Child of God," Hymns, Salt Lake City, UT: The Church of Jesus Christ of Latter-day Saints, 1981. 
The Canadian Temple as a Symbol of Mormon Reintegration into the United States

The Cardston temple's use of Modern American construction symbolized, in monumental and permanent architecture, the Mormon desire to re-integrate into American society. For decades deemed outcasts by the American population, and further separating themselves to an exiled location west of the Rocky Mountains, the Mormon church was for the first time moving toward the same goals as, and in the same direction as American society, rather than against it.

The geometric, harmonious design of the Cardston temple demonstrated several contrasting ideologies to the medievalized structures in Utah. The battlements along the top of the Pioneer temples, along with their massive buttressing systems, referred to their purpose of defense. Like the Pioneer temples, the Card ston temple was an immovable stronghold—a building that, unlike the temples at Kirtland and Nauvoo, would not be abandoned or destroyed by oppressors. Yet the Cardston temple softened some measures of defensibility: the Pioneer temples, facing east in anticipation of the resurrection, often abutted the Rocky Mountains and protected their entryway, whereas the Cardston temple appears almost the same from each of the cardinal directions. ${ }^{207}$ As a building in the middle of an unending prairie, the Cardston temple was approachable when compared to the castle-like Pioneer temples built between mountain ranges - by standing out against the landscape, the Mormon community was asking to be seen. No longer did the sect's architecture in Southern Alberta reflect a desire to blend in with their neighbours but reflected the boldness of standing out. Moving away from a Gothic-inspired design, however, did not eliminate the Cardston temple's connection to Christian origins: the comparison by Card and subsequent commentators to a Maltese cross is unique as the Mormon faith has generally avoided, historically and currently, any references to the symbol of the cross.

${ }^{207}$ Carter, Building Zion, 257. 
No longer did the temple - the very centre of the Mormon experience - contrast the Latter-day Saints with their American contemporaries but was symbolic of similar values and desires.

The Pioneer temples were furthermore, in the eyes of Brigham Young and the nineteenthcentury Saints, a literal representation of the Church's strength against American gentile persecution and served as the seat of the Kingdom of God - the theocracy that governed Utah. The building of the Mormon temple had been viewed as an "instrumental step in hastening the Second Coming," though in 1912, when a temple was announced for Cardston, temple building began to be governed by practical concerns. Whereas there had once been a call for all converts to the Latter-day Saint faith to gather to Zion and relocate to Utah-where temples were located, the temples to which Christ would return at the Second Coming - temples would now come to the people. Today, temples are built when and where the number of Latter-day Saints requires one, a trend that began with the sizable population of Latter-day Saints in Southern Alberta. ${ }^{208}$ A "shifting of loyalties" in the late nineteenth century as Latter-day Saints sought kinship and inclusion with fellow citizens of the United States meant that Utah, as the kingdom of God, was "no longer tenable as a political concept and the twentieth-century temples have consistently avoided any motifs suggesting governmental aspirations like those so militantly proclaimed by the Salt Lake temple."209 Laurel B. Andrew argues that when the Church began to build up its communities outside of Utah, there was no longer a need for a "physical concentration [of Church members] to establish a temporal kingdom." What was instead sought was a "feeling of community within the larger American context. America, though still the land of promise, had lost its exclusivity."210 The Cardston temple, as a result, features only smooth edges and lacks

\footnotetext{
208 Ibid, 281.

209 Andrew, "The Nineteenth-Century Temple Architecture of the Latter-day Saints," 282.

210 Ibid, 282-3.
} 
any of the buttresses or retaining walls found in the Pioneer temple designs. The castle-like connection to God's government had been eliminated. Building a temple in Canada, in an American Modern style, clearly demonstrates that the exclusionist emphasis of the Mormon church had come to an end.

\section{Conclusion}

The Church of Jesus Christ of Latter-day Saints would never return to their Pioneer temple architecture, though they did return to principles of Classicism. Following the Cardston and Laie temples, a temple was built in Mesa, Arizona the following decade. Pope and Burton also submitted a design to this competition, divorcing their Wrightian tradition in favour of a more classical one. ${ }^{211}$ The proposal mimicked their Cardston design in its use of thick decorative piers along the façade and roughly pyramidal shape (see fig. 35). Young and Hansen's winning design, however, contained a flat roof and sculpted frieze. (see fig. 36).

Subsequent temples throughout the early twentieth century continued to be built with a progressive floor plan, though even that symbolic function ceased after the Los Angeles temple. Each early temple demonstrated its denoted purpose of bringing the individual closer to God throughout the temple ceremony with a progressive floorplan where a visitor was physically elevated in the building with each stage of the ceremony. The use of an annexed area served as a portal between the world and the temple proper, and the temple had many connotations: as the House of God, the buildings were to be beautiful, slightly intimidating, and other-worldly through both scale and decoration.

211 Anderson, “The Early Twentieth Century Temples," 18. 
Temple floorplans began to standardize and be truly duplicated in the mid nineteenth century, but it wasn't until the 1990s, when church President Gordon Hinckley introduced a standardized temple model in an effort to build multiple temples in a short amount of time, that a standardized temple plan was executed en masse. Between 1997 and 2002 over forty Latter-day Saint temples were built throughout the world (when fewer than fifty had existed previously), with the intent of allowing church members all over the world to more easily access temple ordinances. ${ }^{212}$ The temples built within this five year span were yet another radical departure from the temple standard. The new structures were miniscule, strictly utilitarian, and contained the fewest possible rooms and administrative spaces. Canada alone received three of these temples: Edmonton, Montreal, and Halifax were all chosen as sites for new temple structures (see figs. 37 and 38). Decoration was sparse, and most importantly, the temple no longer denoted the same meaning: gone were the annexes and the progressive stepped floor plan that had been important in creating meaning in the temple space. Gone were the basement baptistries. Gone were the murals. The individual was no longer physically assisted to ascend in elevation along the path of a symbolic journey to heaven. Yet to adherents of the Church of Jesus Christ of Latter-day Saints, the connotation did not change at all: a mental habit had been formed. The temple was still a place where the visitor was led closer to God, and the temple was still considered a place of beauty, despite a decreased emphasis on architectural symbolism and rich adornment. Mormons visiting these ritual spaces view the temple as beautiful not for its architecture but for its religious significance. In discussing the connotations associated with Gothic revival architecture, Umberto Eco notices this exact same disparity. Churches in New York City were designed to express verticality associated with leading the "soul Godward"

\footnotetext{
${ }^{212}$ Gordon B. Hinckley, "Some Thoughts on Temples, Retention of Converts, and Missionary Service," General Conference, Salt Lake City, Utah. October 1997.
} 
through Gothic revival architecture. ${ }^{213}$ The connotations associated with Gothic architecture are so deeply rooted, Eco argues, that although the skyscrapers surrounding these places of worship effectively miniaturize the churches in vertical comparison, the churches still hold the same value and express the same message as Gothic churches nearly a millennium ago. They are still "read on the basis of codes that permit one to recognize them as vertical" despite the verticality of the skyscraper. ${ }^{214}$

The Cardston temple ended the need for Church members to physically gather to Zion in Utah. Now, a community could figuratively build Zion among themselves throughout the world. A temple in their midst would symbolize that they had succeeded in creating a population that could sustain, both physically and spiritually, such a sacred centre. While the Pioneer temples had represented the solidarity, isolation, unease and defensiveness of the Mormon community in Utah, the Cardston temple's modern American design reflects a desire to integrate into American society. I have argued that this shift occurs in part due to the state of Utah being initiated into the American union. The Cardston temple, with its Modernist architecture, symbolized a conscious move to the adoption of American architectural ideals - and subsequently represented the Church's adoption of American values. Rather than using architecture to express a division between the American and the Mormon people, the Cardston temple adopted mainstream building methods and designs common in the United States. It is somewhat ironic that the first "American" temple was built in Canada, although I would propose that this is coincidental: the Mormon community in southern Alberta was composed of American immigrants led by an American church, and was simply the next largest Mormon community in need of, or able to support the construction of, a temple. The Americanized architecture trend continued in the next

\footnotetext{
213 Eco, "Semiotics of Architecture," 181.

214 Ibid.
} 
two temples, built in Laie, Hawaii and Mesa, Arizona. Taken together, the patterns of early temple architecture trace a complex journey of the Mormon community's cultural and national identity from the nineteenth and into the early twentieth centuries. 


\section{Bibliography - Primary Sources}

\section{$\underline{\text { Archival Material }}$}

Angell, Truman O. "Truman O. Angell, 1810-1887: Autobiography." Published in Our Pioneer Heritage 10 (1967), available online at https://www.boap.org/LDS/EarlySaints/TAngell.html.

Cardston Alberta Temple: An Historical Record. University of Lethbridge Digitized Collections.

Edward J. Wood collection, 1884-1982; Journals, 1912 January-1915 December. Church History Library, MS 7313.

"Highland Park Historic District," Utah National Register Collection (Utah Division of State History, 1998), 17. Archived in the collections of the University of Utah and available online at https://collections.lib.utah.edu/ark:/87278/s6t47gwf.

Journal of Discourses, 26 vols. London: LDS Booksellers Depot, 1854-86.

"Rudolf Herr's story as told by his granddaughter Elayne Fitzner and grandson John Hollingsworth," Cardston Historical Society Digital Archive, PH 8133, Box 1, fd. 2, no. 24-26.

Shaw, Keith. Chief Mountain Country: A History of Cardston and District, Vol 1. (Cardston: Cardston and District Historical Society, n.d.), 173. Accessed 17 April 2019, https://web.archive.org/web/20110516202721/http://www.ourroots.ca/e/page.aspx?id=80 3665 .

"Talk in Stake General Priesthood," Jan 21, 2001, Cardston Historical Society Digital Archive.

\section{$\underline{\text { Newspapers }}$}

“A Mormon Temple In Alberta Town,” Leader-Telegram (Wed, Dec 17, 1919), 8.

“A Quarter of a Million Dollars,” The Winnipeg Tribune (Sat, May 31, 1913), 12.

“Approved Design for Temple in Alberta Province," Deseret Semi-Weekly News, 2 January 1913.

Calgary Herald (Thu, Jan 15, 1914), 7. 
Card, J.Y. "Alberta Temple is Masterpiece of Construction and Finish," Lethbridge Herald (Aug 28, 1923).

“Cardston Temple to Be Dedicated August 26," Vernal Express (Fri, Aug 3, 1923).

“Cardston Temple,” Calgary Herald (Fri, Aug 4, 1922), 19.

“Cardston: The Temple City,” The Lethbridge Herald (Thu, Jun 7, 1923), 5.

“Great Mormon Temple At Cardston,” Calgary Herald (Sat, Jul 9, 1921).

"Great Mormon Temple Constructed At Outlay of $\$ 1,250,000$ in City of Card ston Is Nearing Completion," Salt Lake Telegram (Sun, Oct 24, 1920), 2.

“Huge Temple Dedicated," Morning Register (Sun, Sep 2, 1923), 15.

“Joseph Smith.” Times and Seasons 5, no. 14 (Aug 1, 1844), 607.

"Marble and Lumber From Lands Remote Used by Mormons for Card ston Temple," The Vancouver Sun (Sun, Jul 3, 1921), 7.

"Million Dollar Mormon Temple Dedicated in Canada Today," Buffalo Courier (Sun, Aug 26, 1923), 29.

“Mormon Temple for Alberta," Chippewa Harald-Telegram (Sun, Feb 23, 1913), 12.

"Mormon Temple in Canada First On British Soil." The Daily Republican (Mon, Jun 1, 1914), 3.

“Mormon Temple is Designed on Straight Lines." Popular Mechanics vol. 37.3 (March 1922), 333.

“Mormons Build Odd Temple in Canadian Town." Popular Mechanics vol. 34 (Jul - Dec 1920), 180.

“Mormons in Canada." The Windsor Star (Wed, Dec 10, 1913), 7.

Peterson, Daniel. “The Inspired Plans for the Kirtland Temple.” Deseret News. 20 Oct 2016.

"Renovation Completed at Alberta Temple." Church News (July 8, 1961).

"Seventh Temple of Mormon Church Dedicated." The Ogden Standard (Thu, Sep 23, 1915), 6,

“Site for Temple." Deseret Evening News (28 July 1913), 2.

The Transcript Bulletin (Fri, June 6, 1919), 7. 


\section{$\underline{\text { Latter-day Saint Publications and General Conference Addresses }}$}

Allred, Silvia H. "Holy Temples, Sacred Covenants." General Conference. Salt Lake City, Utah. October 2008.

Anderson, Paul L. "First of the Modern Temples." Ensign. July 1977.

Card, Joseph Y. "The Cardston Temple." The Improvement Era 26, no. 11 (September 1923): 1000-1009.

Costa. Claudio R. M. “Gather to the Temple.” Ensign. December 2008.

Gaunt, LaRene Porter. “Taking Temples to the People.” Ensign. March 2000.

"Gospel Topics: Temples." The Church of Jesus Christ of Latter-day Saints, n.d. Accessed 3 March 2020. https://www.churchofjesuschrist.org/study/manual/gospeltopics/temples?lang=eng.

Hinckley, Gord on B. "Some Thoughts on Temples, Retention of Converts, and Missionary Service.” General Conference. Salt Lake City, Utah. October 1997.

Hymns. Salt Lake City, Utah: The Church of Jesus Christ of Latter-day Saints, 1981.

McKay, David O. “The Purpose of Temples.” Ensign. January 1972.

Nelson, Russel M. "Revelation for the Church, Revelation for our Lives." General Conference. Salt Lake City, Utah. April 2018.

Nelson, Russell M. "Becoming Exemplary Latter-day Saints." General Conference. Salt Lake City, Utah. October 2018.

Oaks, Dallin H. "Truth and the Plan.” General Conference. Salt Lake City, Utah. October 2018.

"Our Premortal Life." Chapter 6 in Doctrines of the Gospel Student Manual. Salt Lake City: The Church of Jesus Christ of Latter-day Saints, 2010.

Packer, Boyd K. Preparing to Enter the Holy Temple. Salt Lake City: The Church of Jesus Christ of Latter-day Saints, 2002.

"Passing News." Improvement Era 16, no. 5 (March 1913), 524.

“Questions and Answers.” Ensign. June 2014. 
Saints: The Story of the Church of Jesus Christ in the Latter Days, Vol. 1. Salt Lake City: The Church of Jesus Christ of Latter-day Saints, 2018.

“Sharing Time: The Temple is a Place of Revelation.” Friend. May 1993.

Uchtdorf, Dieter F. “Believe, Love, Do.” General Conference. Salt Lake City, Utah. October 2018.

Widtsoe, John A. "Looking Toward the Temple.” Ensign. February 2010.

“2018 Statistical Report for 2019 April Conference.” Newsroom of the Church of Jesus Christ of Latter-day Saints. 6 April 2019.

\section{Bibliography - Secondary Sources}

A History of the Mormon Church in Canada. Lethbridge: The Lethbridge Alberta Stake, 1968.

Anderson, Paul L. "The Early Twentieth Century Temples," Dialogue: A Journal of Mormon Thought 14, no. 1 (1981): 9-19.

Anderson, Paul L. "Truman O. Angell: Architect and Saint," in Supporting Saints: Life Stories of Nineteenth-Century Mormons. Provo, UT: Religious Studies Center, Brigham Young University, 1985.

Andrew, Laurel B. The Early Temples of the Mormons. Albany: State University of New York Press, 1978.

Andrew, Laurel Brana Blank. "The Nineteenth-Century Temple Architecture of the Latter-day Saints.” Dissertation. University of Michigan, 1973.

Arrington, J. Earl. "William Weeks, Architect of the Nauvoo Temple." BYU Studies Quarterly 19, no. 3 (1979): 337-360.

Barthes, Roland. "The Rhetoric of the Image" (1964). Available online at https://faculty.georgetown.edu/irvinem/theory/Barthes-Rhetoric-of-the-image-ex.pdf.

Bennett, Richard, and Arran Jewsbury. "The Lion and the Emperor: The Mormons, The Hudson's Bay Company, and Vancouver Island, 1846-1858, BC Studies no. 128 (Winter 2000/2001): 37-62. 
Bennion, Marjorie H. “William Weeks' Nauvoo Temple Drawings.” Mormon Historical Studies 31 (Spring 2002): 73-90.

Boddy, Trevor. Modern Architecture in Alberta. Regina: Canadian Plains Research Centre, 1988.

Brassard, Brooke Kathleen. "Prairie School in the Prairie: An Architectural Journey Through Mormon History in Southern Alberta, 1888-1923." Journal of Mormon History 40, no. 2 (2016): 139-167.

Brassard, Brooke. "Thirsty Land into Springs of Water: Negotiating a Place in Canada as Latterday Saints, 1887-1947.” Dissertation. University of Waterloo, 2018.

Brereton, Joel P. "Sacred Space,” In The Encyclopedia of Religion, ed. Mircea Eliade, vol. 11. New York: Macmillan, 1987.

Buerger, David. "The Development of the Mormon Temple Endowment Ceremony." Dialogue: A Journal of Mormon Thought 20, no. 4 (Winter 1987): 33-76.

Bushman, Claudia L. Contemporary Mormonism. Westport: Praeger, 2006.

Carter, Sarah. The Importance of Being Monogamous: Marriage and Nation Building in Western Canada to 1915. Edmonton: The University of Alberta Press, 2008.

Carter, Thomas. Building Zion: The Material World of Mormon Settlement. Minneapolis: University of Minnesota Press, 2015.

Coffman, Peter. "The Gibbsian Tradition in Nova Scotia." In Matthew M. Reeve (ed.), Tributes to Pierre du Prey: Architecture and the Classical Tradition, from Pliny to Posterity. London/Turnhout: Harvey Miller Publishers, 2014.

D'Alleva, Anne. Methods \& Theories of Art History, $2^{\text {nd }}$ ed. London: Laurence King Publishing, 2014.

Dew, Sheri. Go Forward with Faith: The Biography of Gordon B. Hinckley. Salt Lake City, Utah: Deseret Book Company, 1996.

Durand, Guillaume. The Symbolism of Churches and Church Ornaments, ed. by J.M Neale and Benjamin Webb. Charles Scribner's Sons: New York, 1893.

Eco, Umberto. "Function and Sign: The Semiotics of Architecture," in Rethinking Architecture: A reader in cultural theory, ed. Neil Leach. Lond on: Routledge, 1997.

Eliade, Mircea. "Sacred Space and Making the World Sacred." In The Sacred and the Profane: The Nature of Religion. New York: Harper, 1959. 
Gates, Susa Young. The Life Story of Brigham Young. Freeport: Books for Libraries Press, 1930.

Hamilton, Mark C. Nineteenth Century Mormon Architecture and City Planning. Oxford: Oxford University Press, 1995.

Hucker, Jacqueline. "The Card ston Temple, Alberta, and Nonconformist Form," Journal of the Society for the Study of Architecture in Canada 23, no.2 (1998): 55-61.

Jones, Candace. and Felipe G. Massa. "From Novel Practice to Consecrated Exemplar: Unity Temple as a Case of Institutional Evangelizing." Organization Studies 34, no. 8 (2013): 1099-1136.

Kieckhefer, Richard. "Architectural Expression and Ways of Being Religious." In The Oxford Handbook of Religion and the Arts, ed. Frank Burch Brown. Oxford: Oxford University Press, 2014. pp. 203-219.

Kramer, Bradley H. "Keeping the Sacred: Structured Silence in the Enactment of Priesthood Authority, Gendered Worship, and Sacramental Kinship in Mormonism.” Dissertation. University of Michigan, 2014.

Larson, Gustive O. The "Americanization" of Utah For Statehood. San Marino, California: The Huntington Library, 1971.

Lehr, John C. "Polygamy, Patrimony, and Prophecy: The Mormon Colonization of Cardston." Dialogue: A Journal of Mormon Thought 21, no. 4 (Winter 1888): 114-121.

Lindsay, Jeff. "The Yoke of Christ: A Light Burden Heavy With Meaning." Interpreter: A Journal of Mormon Scripture 18 (2016): 171-217.

Maitland, Leslie, Jacqueline Hucker, and Shannon Rickets. A Guide to Canadian Architectural Styles. Peterborough: Broadview Press, 1992.

Marx, Leo. The Machine in the Garden. New York: Oxford University Press, 1964.

McConkie, Bruce R. Mormon Doctrine. Salt Lake City, UT: Bookcraft, Inc., 1958.

McConkie, Joseph Fielding. "The Gathering of Israel," in Religious Educator 11, no. 1 (2010): 46-62.

Murray, Stephen. Beauvais Cathedral: Architecture of Transcendence. Princeton: Princeton University Press, 1989.

Onians, John. Bearers of Meaning. Princeton: Princeton University Press, 1988. 
Panofsky, Erwin. Gothic Architecture and Scholasticism. New York: World Publishing, 1951.

Phipps, William E. Supernaturalism in Christianity: Its Growth and Cure. Macon: Mercer University Press, 2008.

Prete, Carma and Roy Prete, eds. Canadian Mormons: History of the Church of Jesus Christ of Latter-day Saints in Canada. Provo: Religious Studies Centre, Brigham Young University, 2017.

Pugin, A. Welby. An Apology for the Revival of Christian Architecture in England. London: John Weale, 1843.

Rand, McNally and Company's Handbook of the World's Columbian Exposition. Chicago: Rand, McNally and Company, 1893.

Richardson, Peter, and Douglas Richardson. Canadian Churches: An Architectural History. Buffalo/Richmond Hill: Firefly Books, 2007.

Roberts, Allen D. Salt Lake City's Historic Architecture. Charleston: Arcadia Publishing, 2012.

Seely, David. Solomon's Temple. London: Thames \& Hudson Ltd, 2007.

Shaw, Edward. Civil Architecture: Or a Complete Theoretical and Practical System of Building. Boston: Marsh, Capen \& Lyon, 1832.

Shipps, Jan. Sojourner in the Promised Land: Forty Years Among the Mormons. Chicago: University of Illinois Press, 2000.

Siry, Joseph. Unity Temple: Frank Lloyd Wright and Architecture for Liberal Religion. Cambridge: Cambridge University Press, 1996.

Smith, Joseph Fielding. Answers to Gospel Questions, v. 4. Salt Lake City, UT: Deseret Book Company, 1963.

von Simson, Otto. The Gothic Cathedral. Princeton: Princeton University Press, 1988.

Watson, Bruce. Light: A Radiant History from Creation to the Quantum Age. New York: Bloomsbury, 2016.

Wood, V.A. The Mormon Temple. Calgary: Detselig Enterprises Limited, 1989. 


\section{Figures}

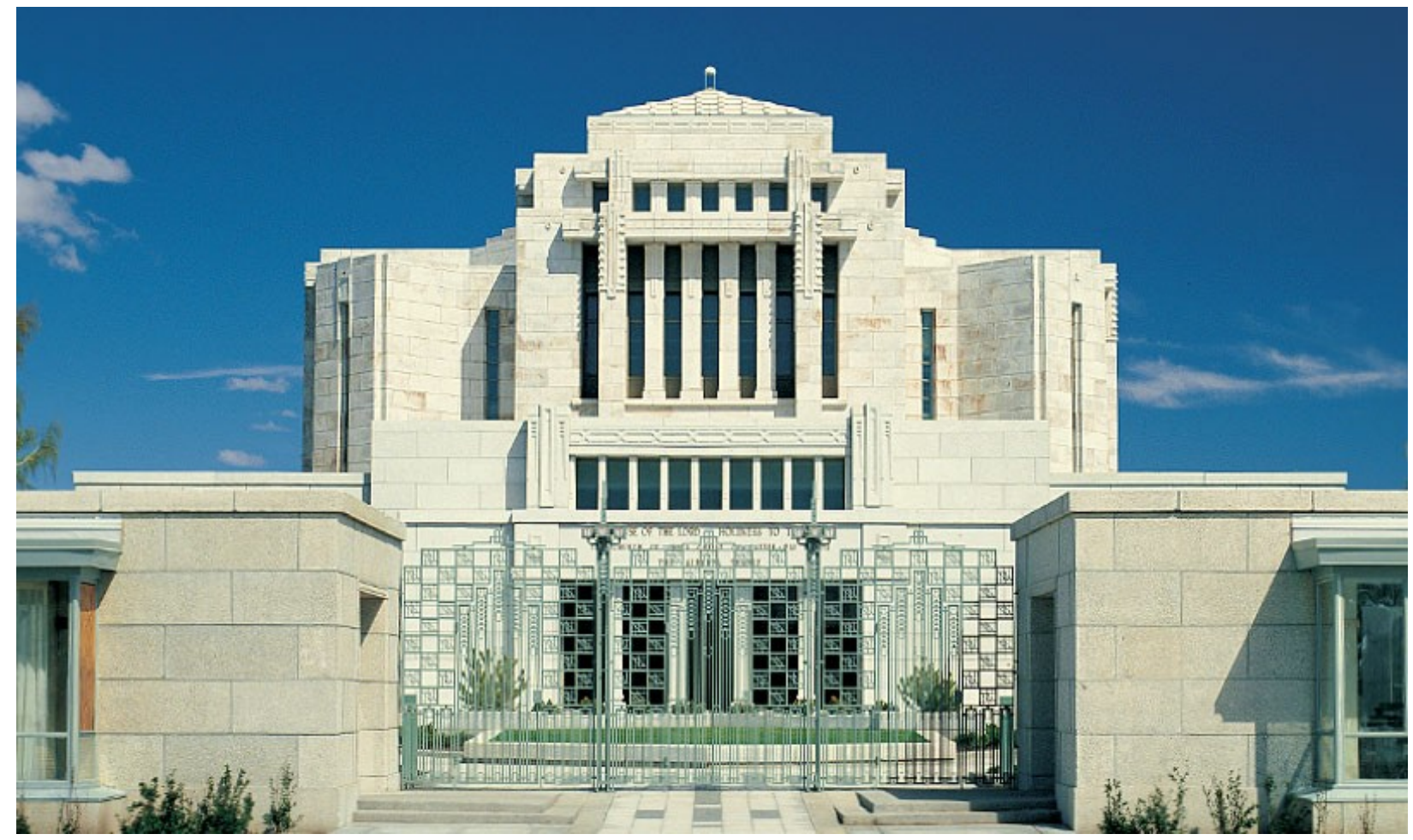

Figure 1: The Cardston temple as it stands today. Image from the Town of Cardston website. 


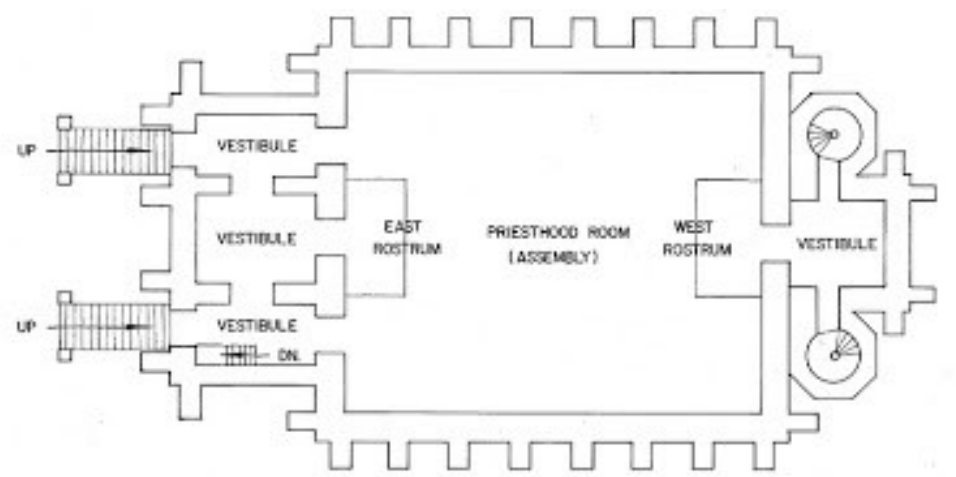

THIRD FLOOR

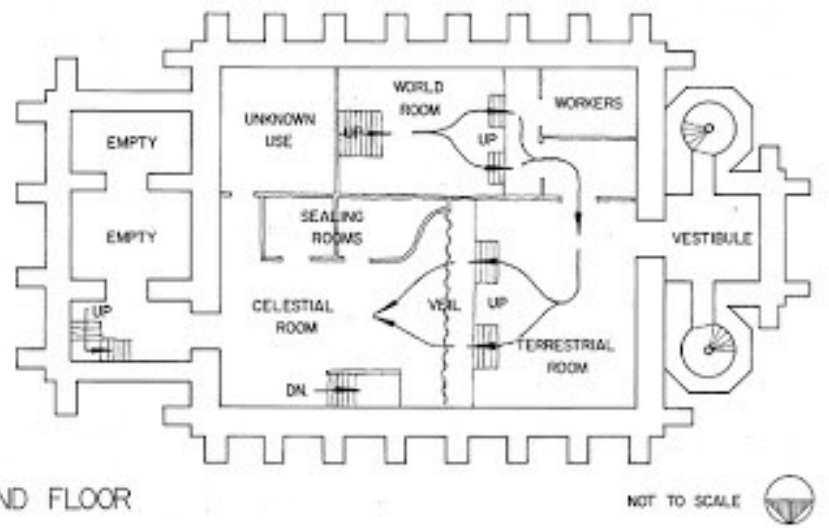

SECOND FLOOR

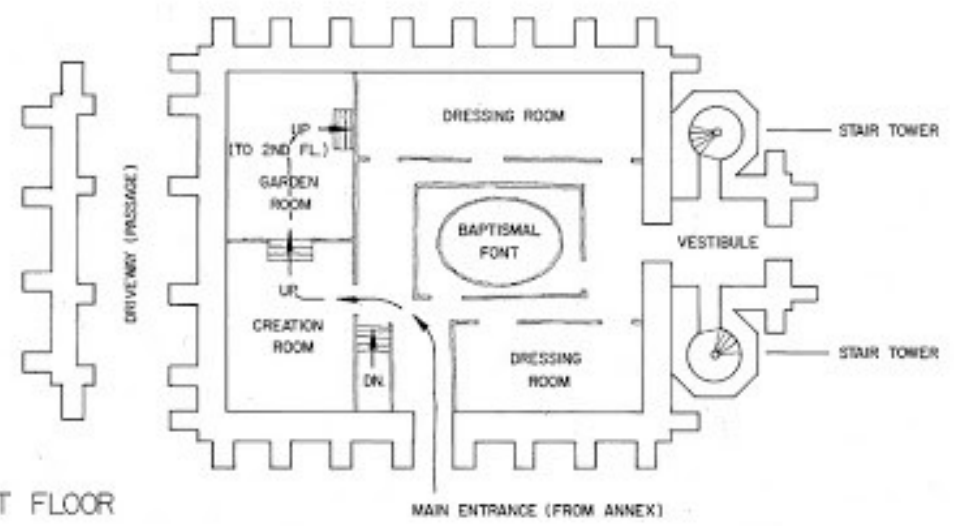

Figure 2: Manti temple floorplan. Thomas Carter, Building Zion, 267. 


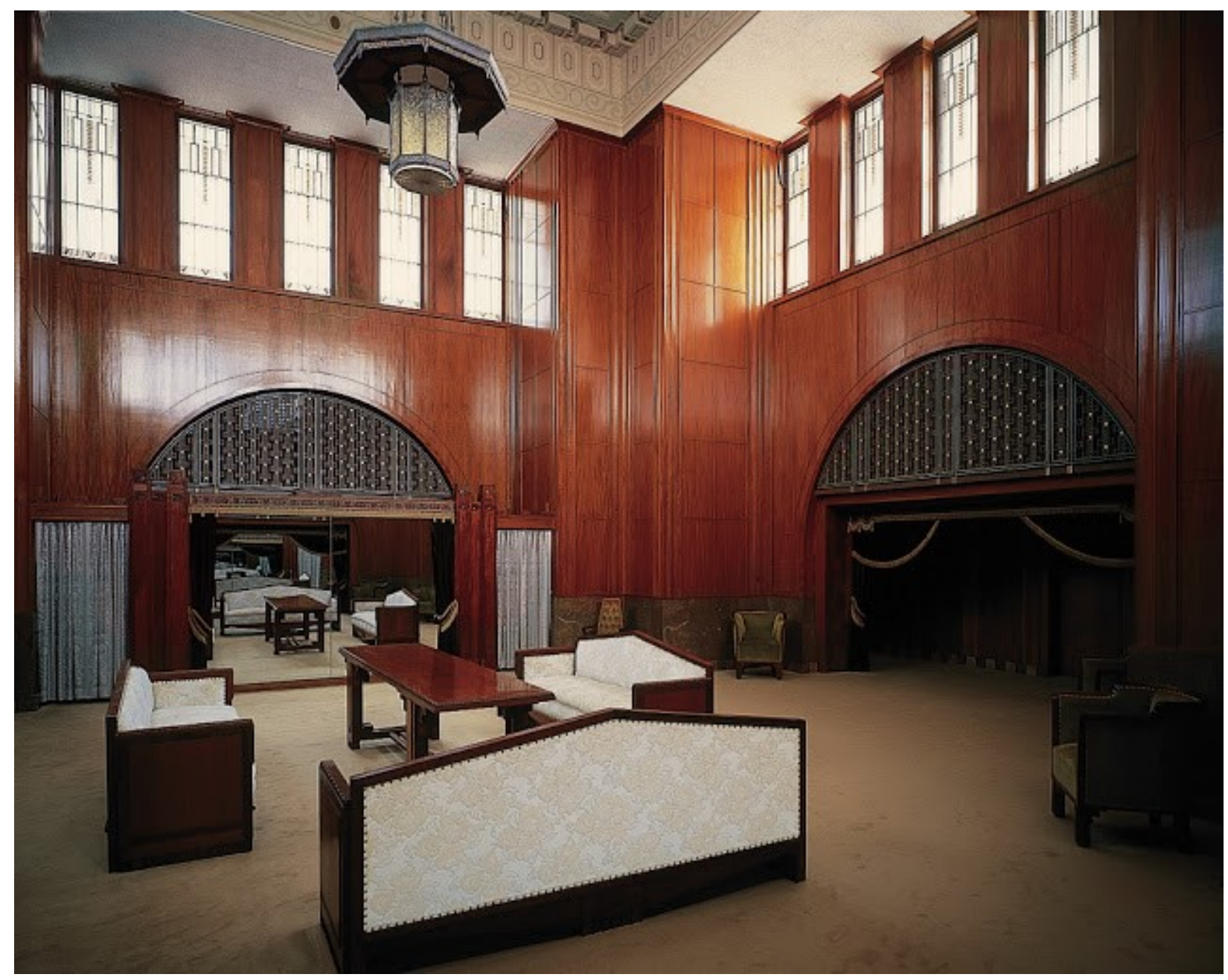

Figure 3: Celestial room, Cardston temple. Image from LDS Pioneer Architecture blog, “Cardston Temple,” 19 Aug 2018. 


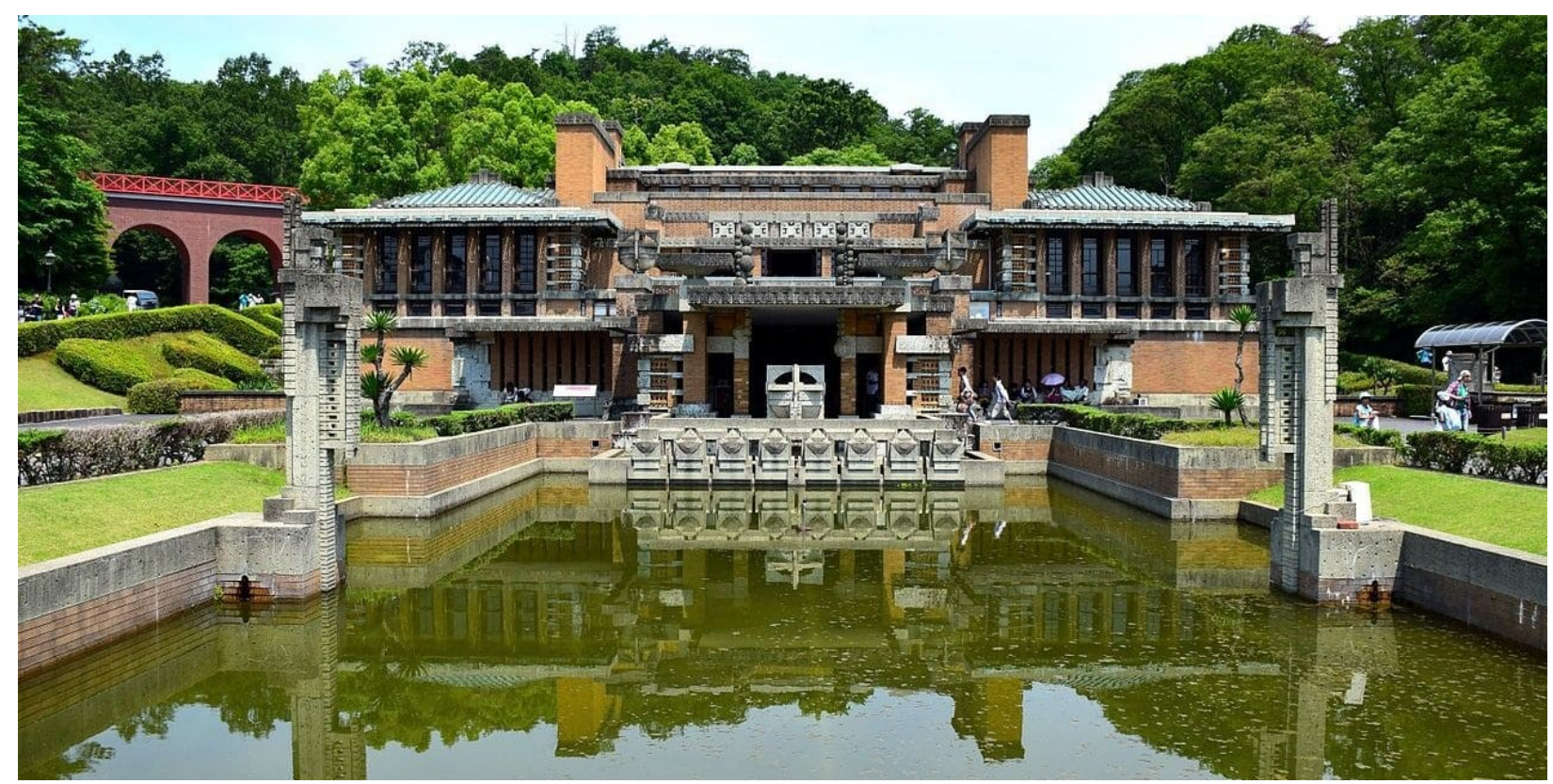

Figure 4: Frank Lloyd Wright's Imperial Hotel, Tokyo. Image from the Frank Lloyd Wright Foundation. 


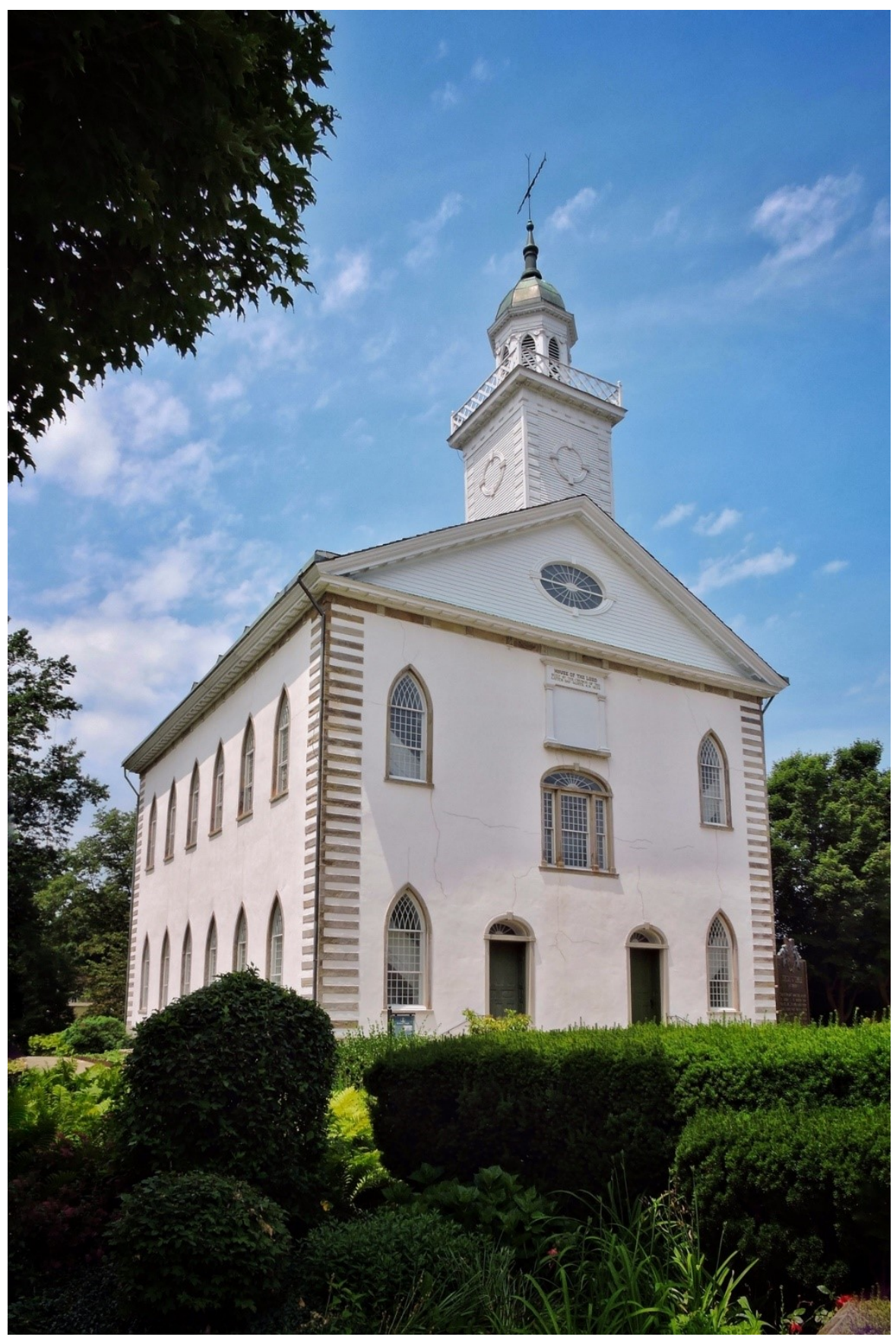

Figure 5: The Kirtland temple. Image from Church of Jesus Christ Temples. 


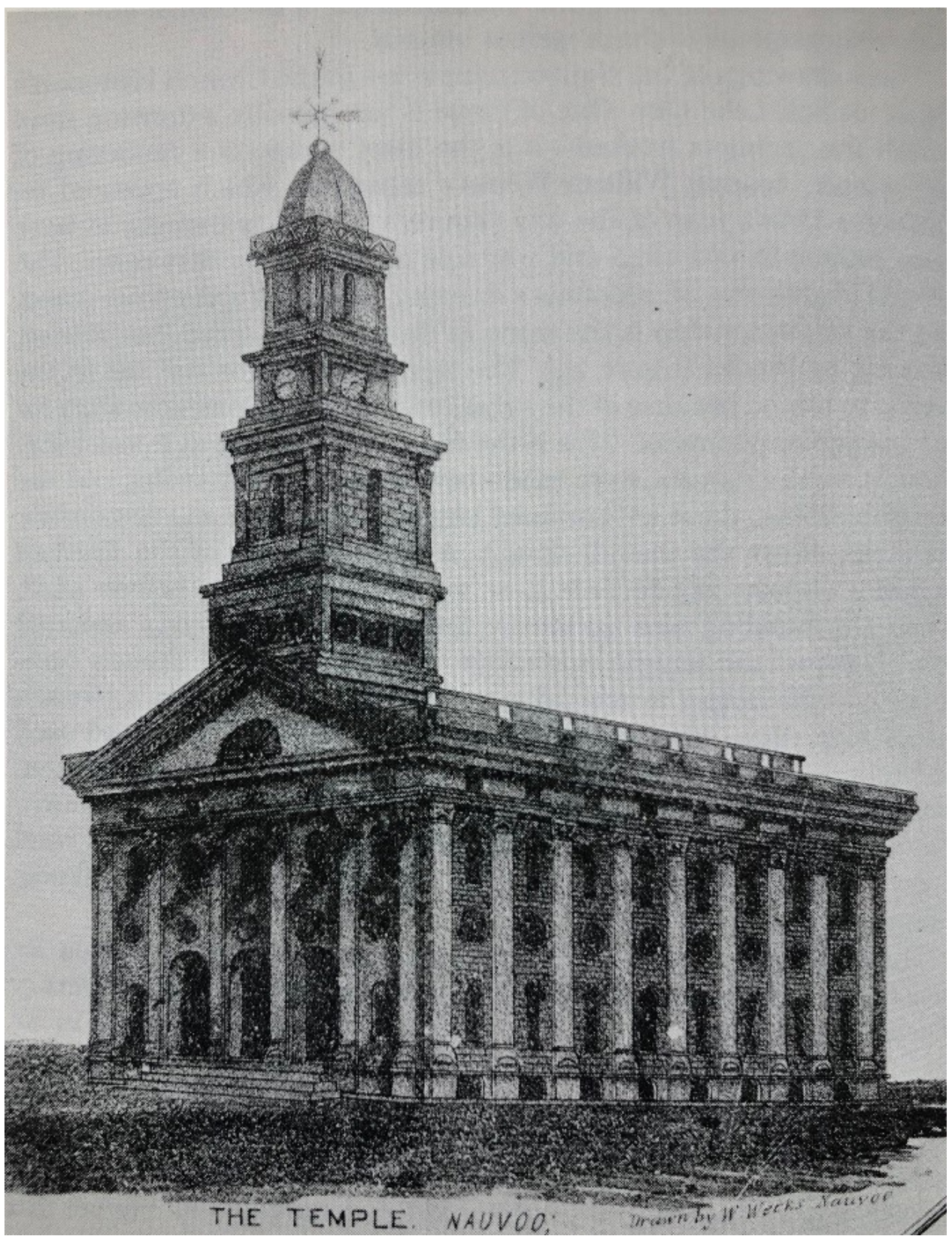

Figure 6: An early design for the Nauvoo temple. Sketch by architect William Weekes. Image from Laurel B. Andrew, The Early Temples of the Mormons, 64. 


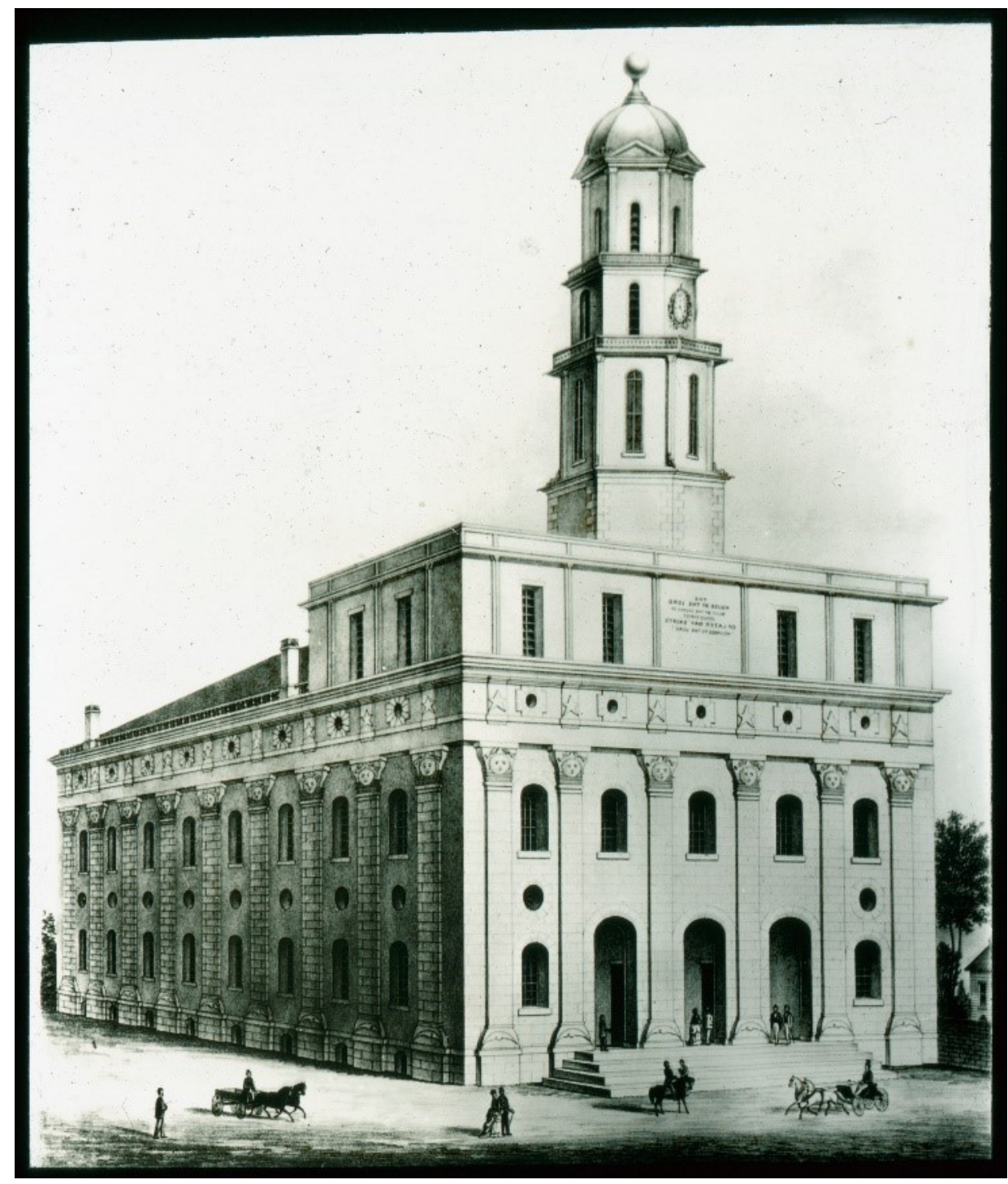

Figure 7: The Nauvoo temple in a later sketch. Church History Library, PH 10362. 


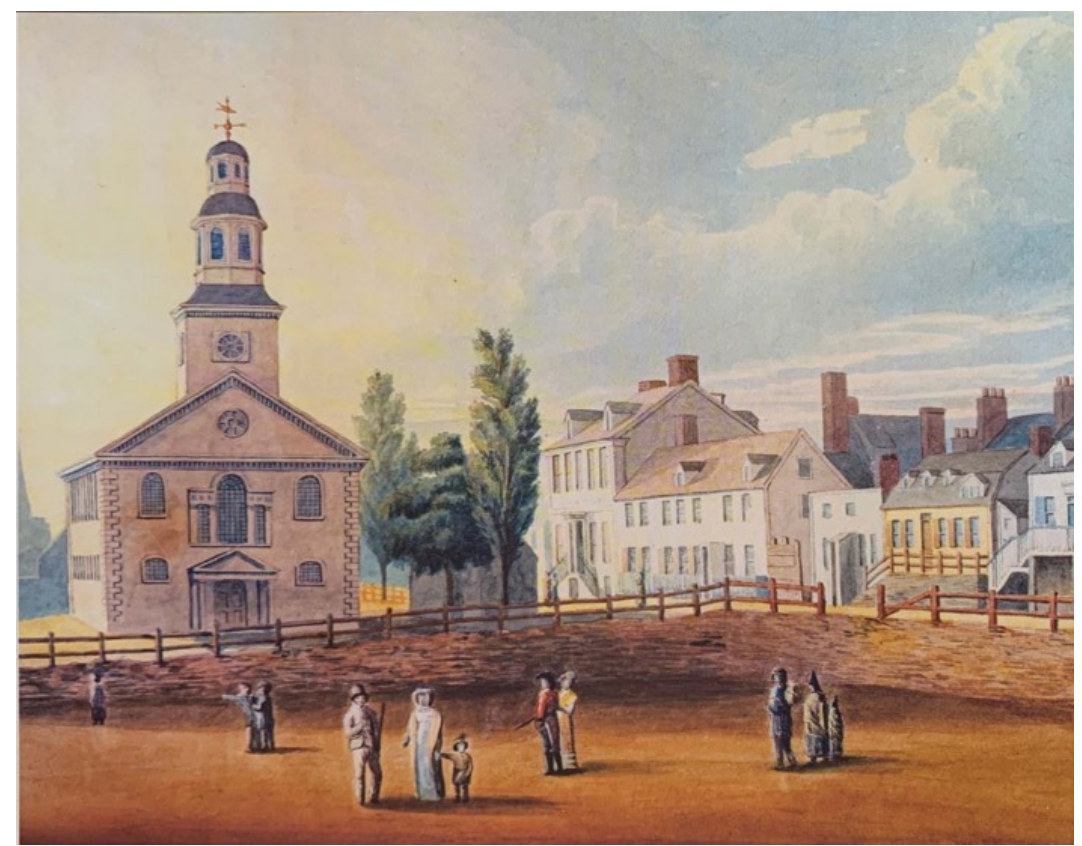

Figure 8: St. Paul's, Halifax. Richardson and Richardson, Canadian Churches, 44.

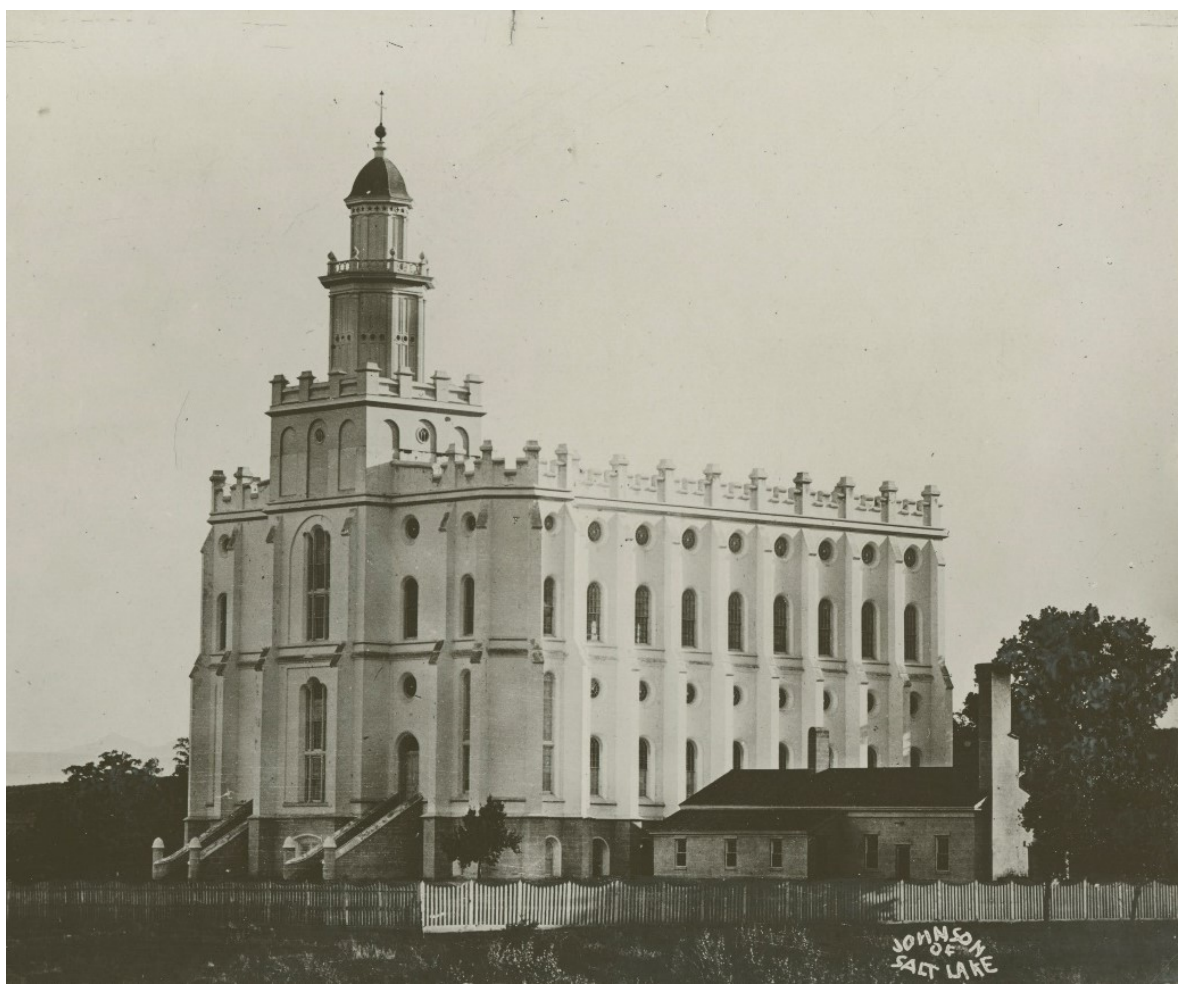

Figure 9: The St. George temple, ca. 1900. Church History Library, PH 1156. 


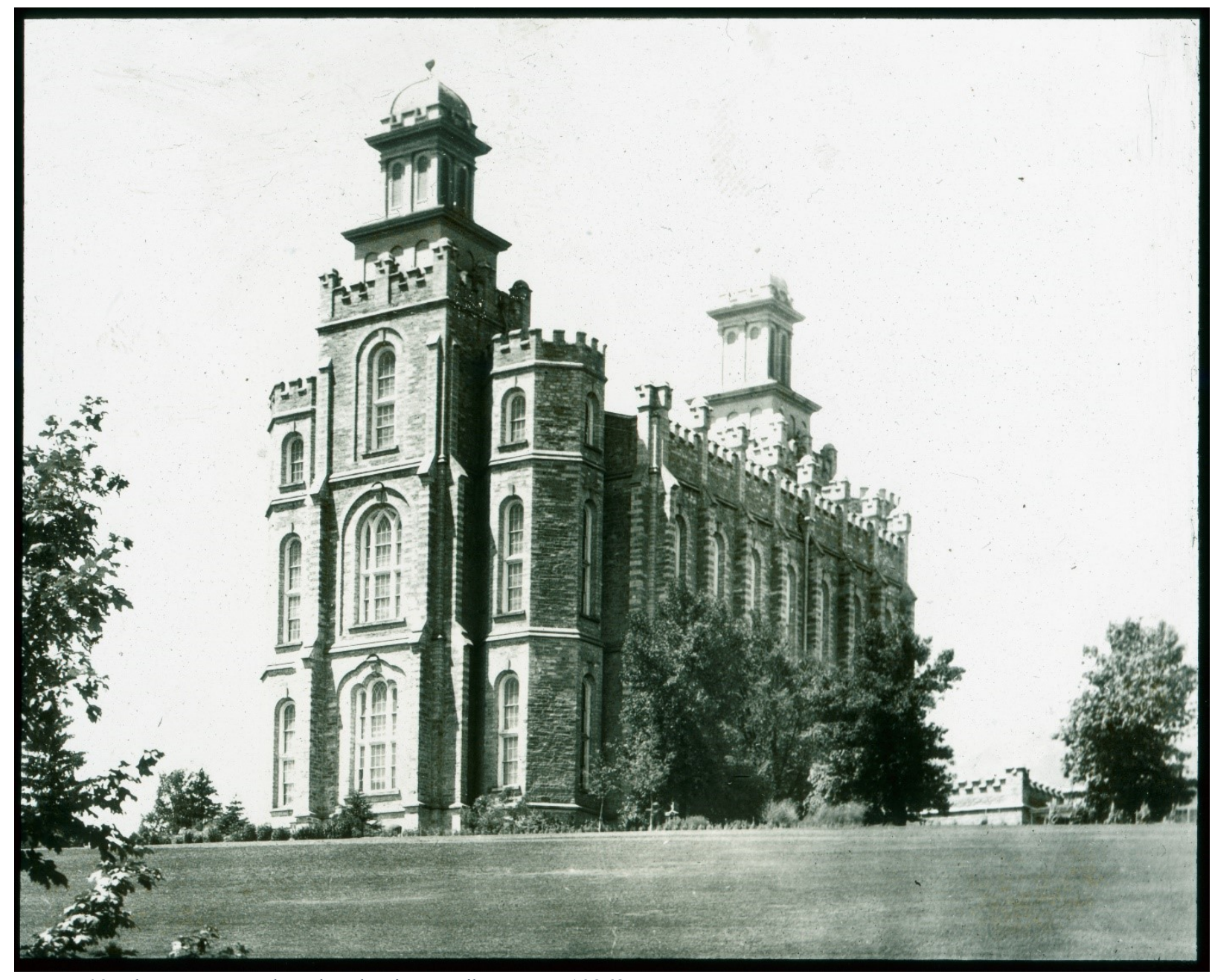

Figure 10: The Logan temple. Church History Library, PH 10362. 


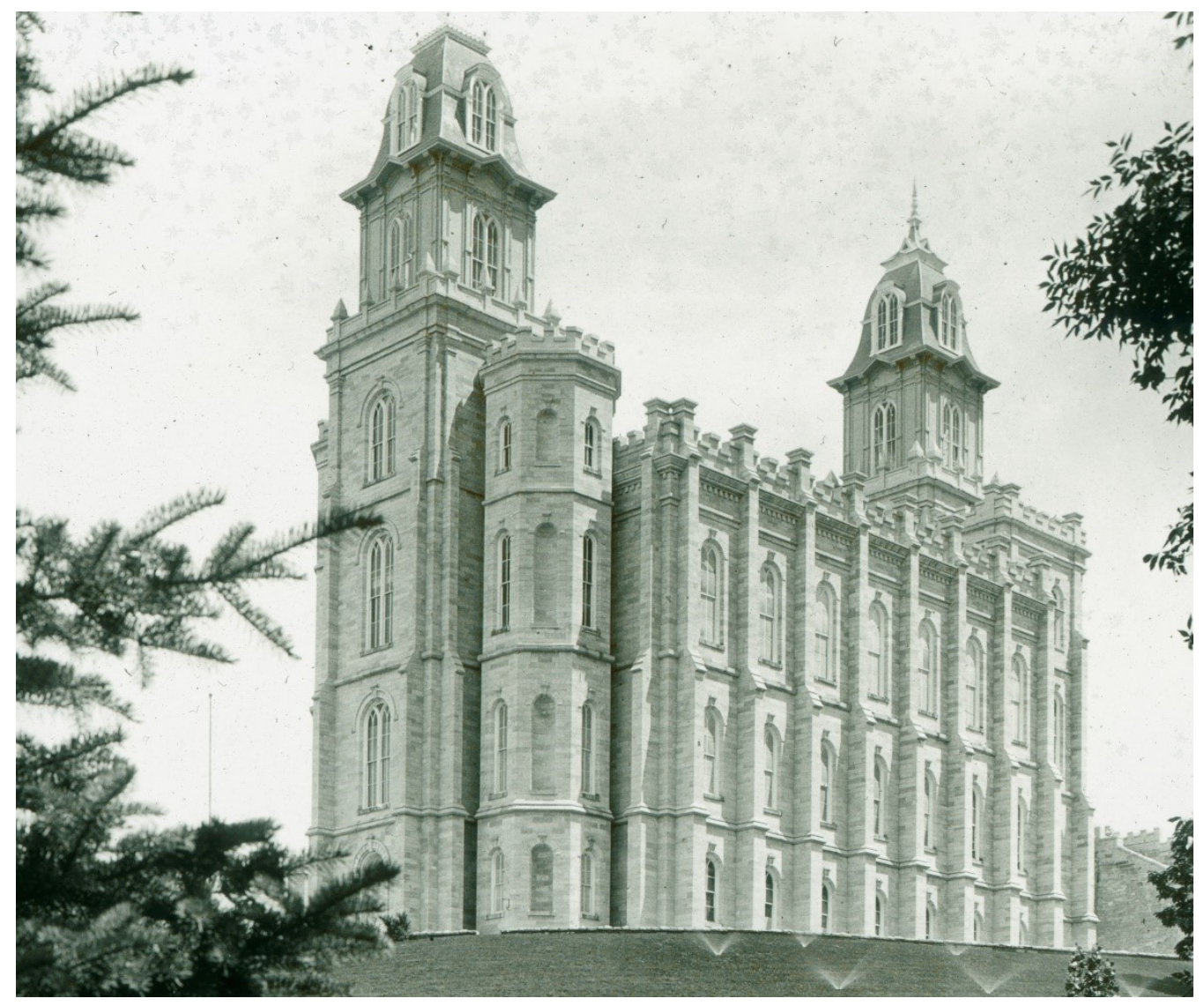

Figure 11: The Manti temple. Church History Library, PH 10362. 


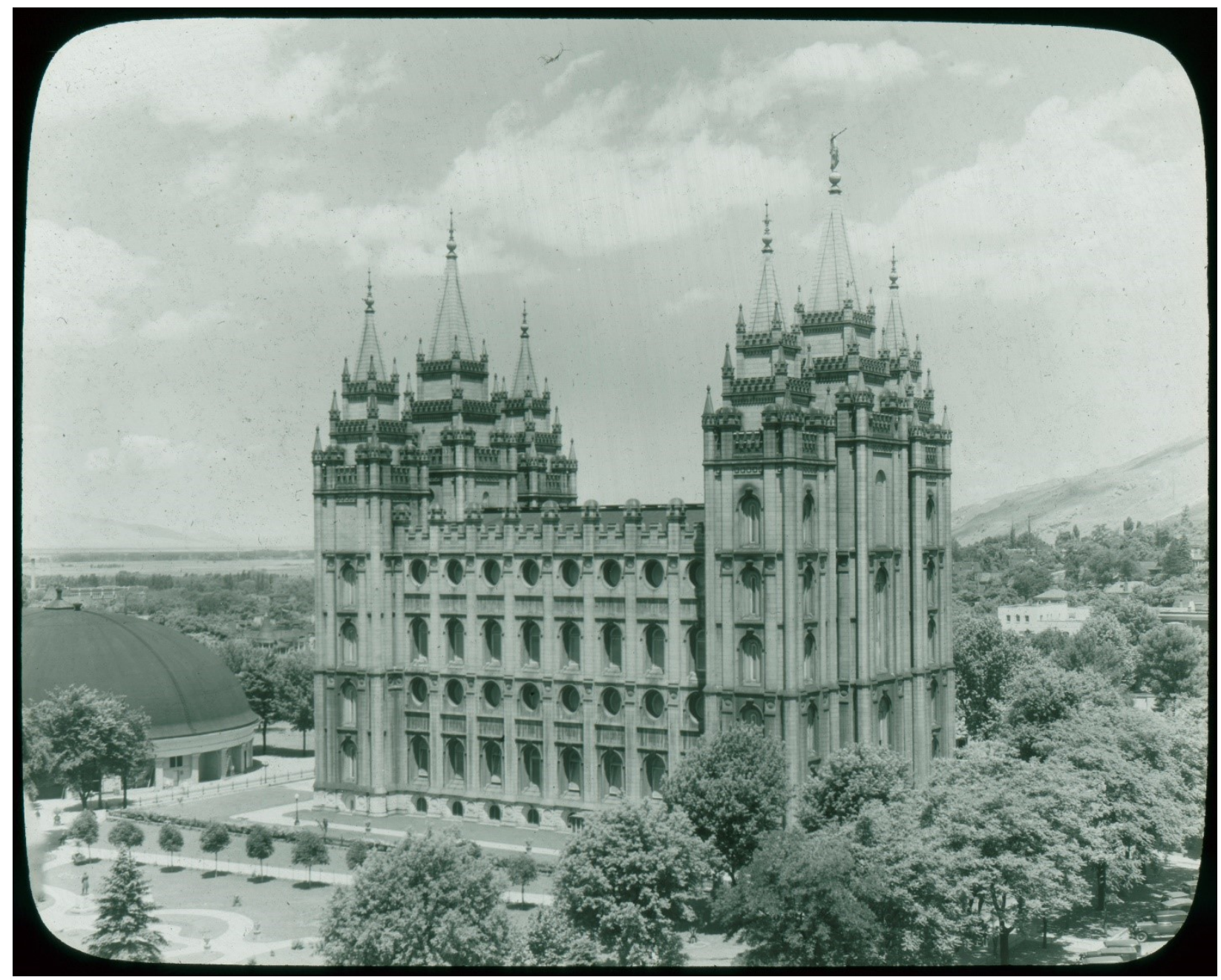

Figure 12: The Salt Lake City temple. Church History Library, PH 10362. 


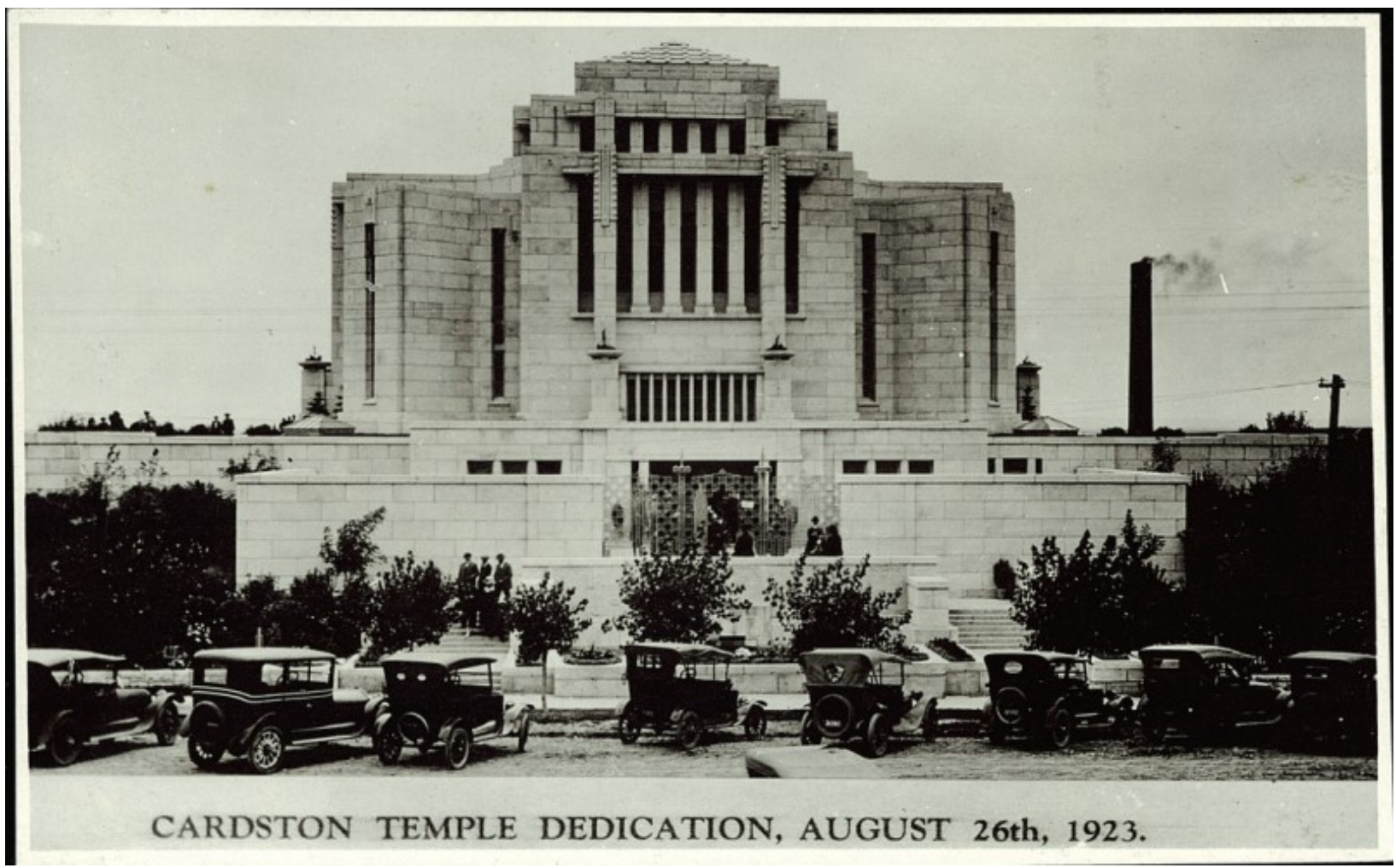

Figure 13: Cardston Temple, 1923. Peel Library, University of Alberta, PC 12050.

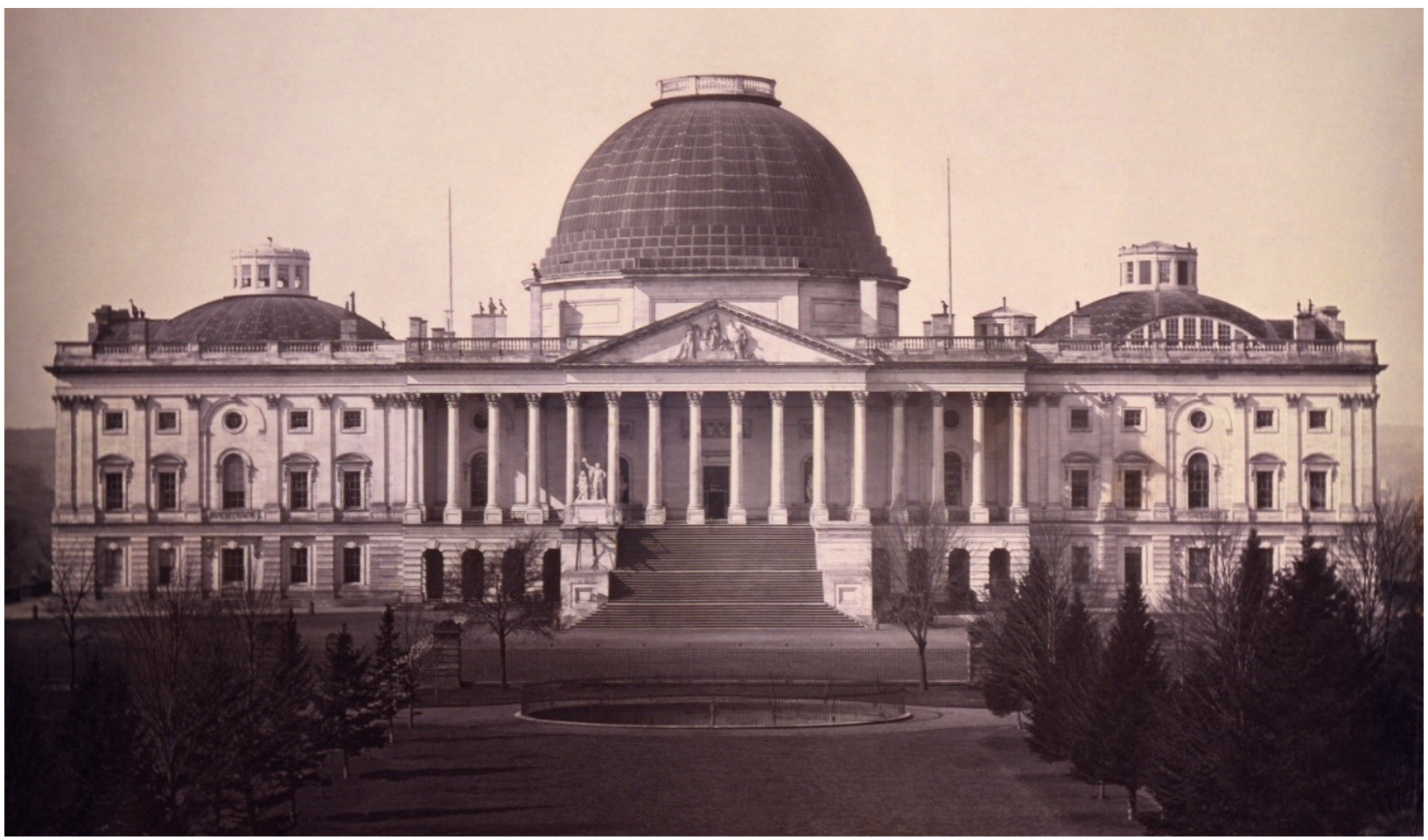

Figure 14: United States Capitol, 1846. Library of Congress, United States Senate. 


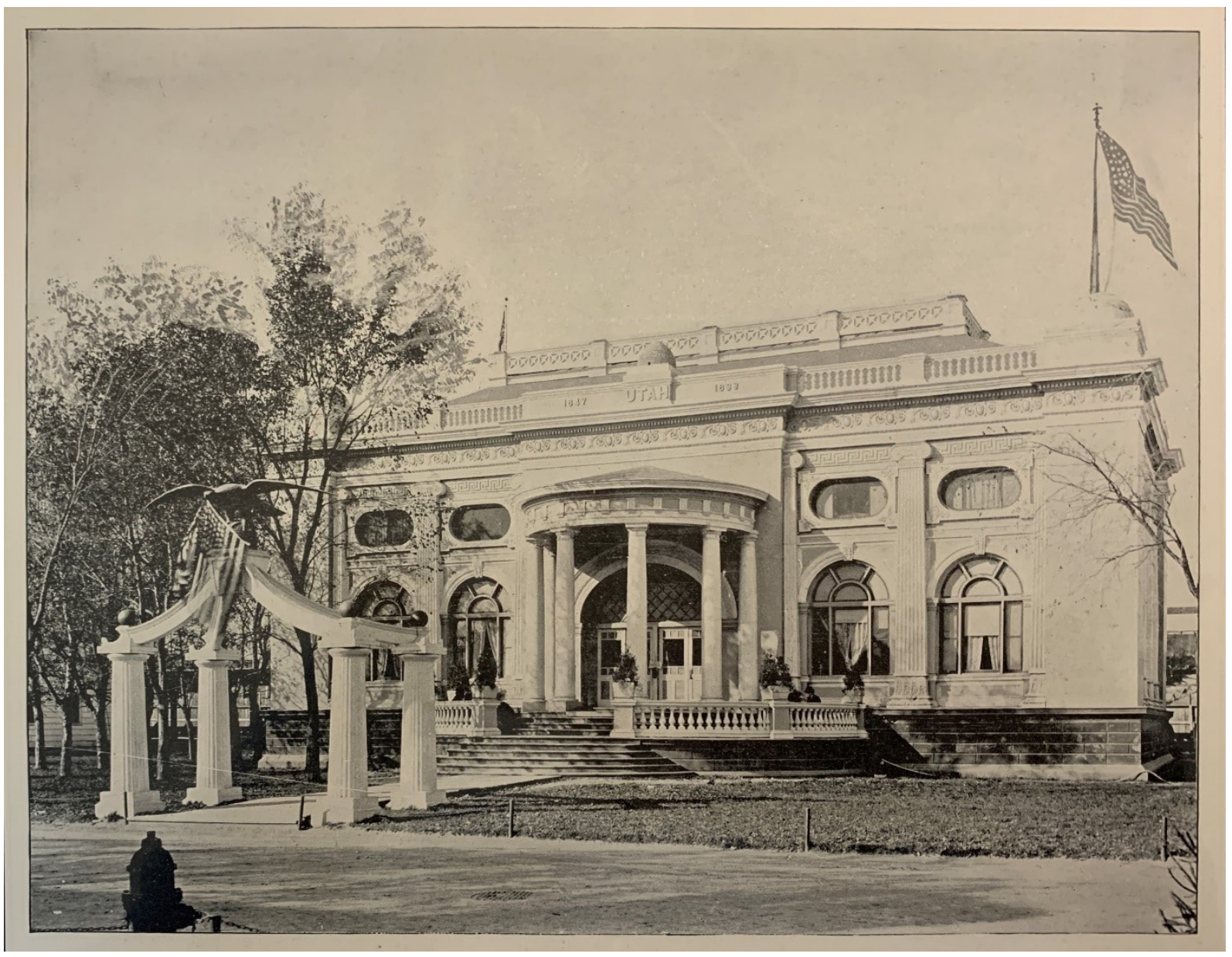

Figure 15: Utah Building, Chicago World's Fair 1893. Photograph in collection of the author. 


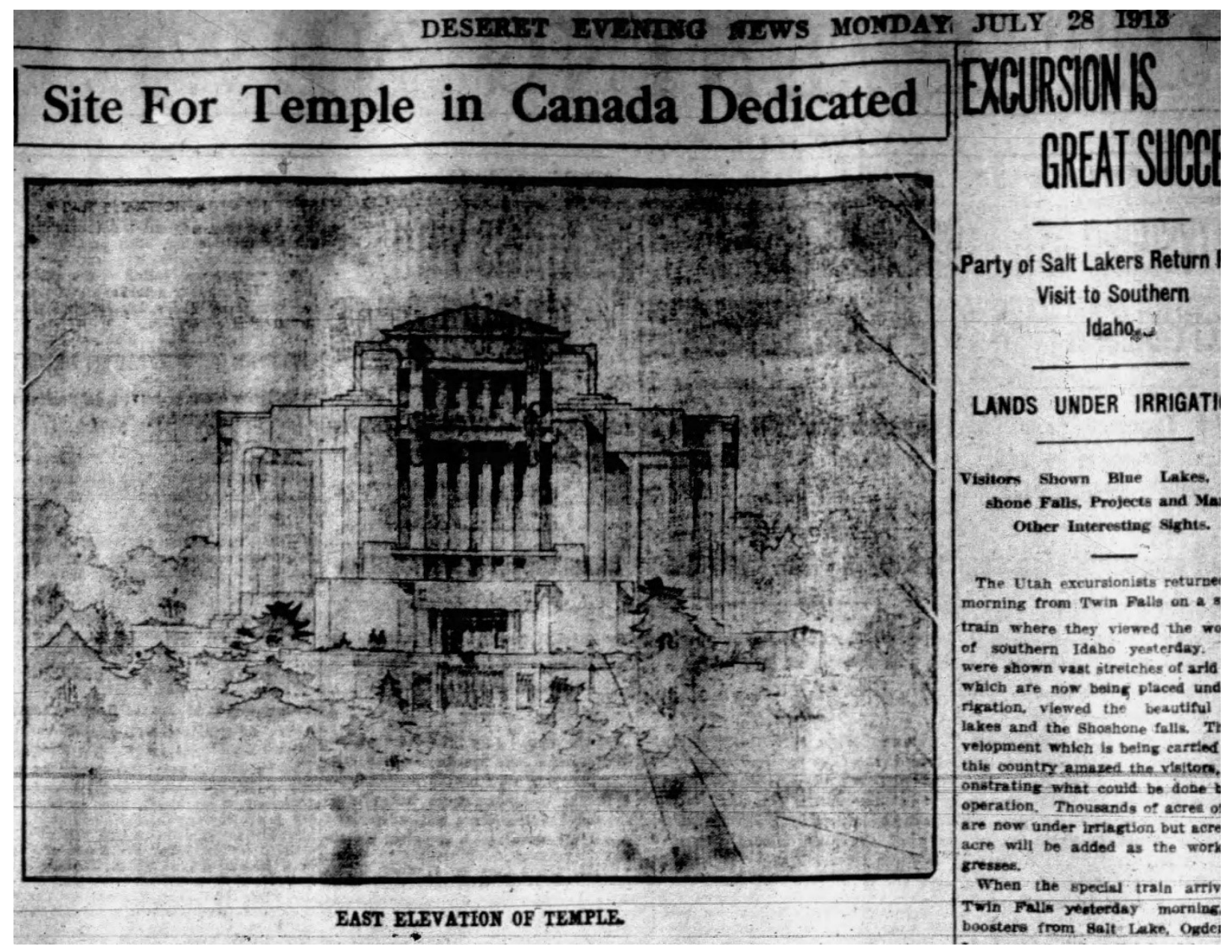

Figure 16: Original Sketch for the Cardston Temple, Deseret Evening News, 28 July 1913. 


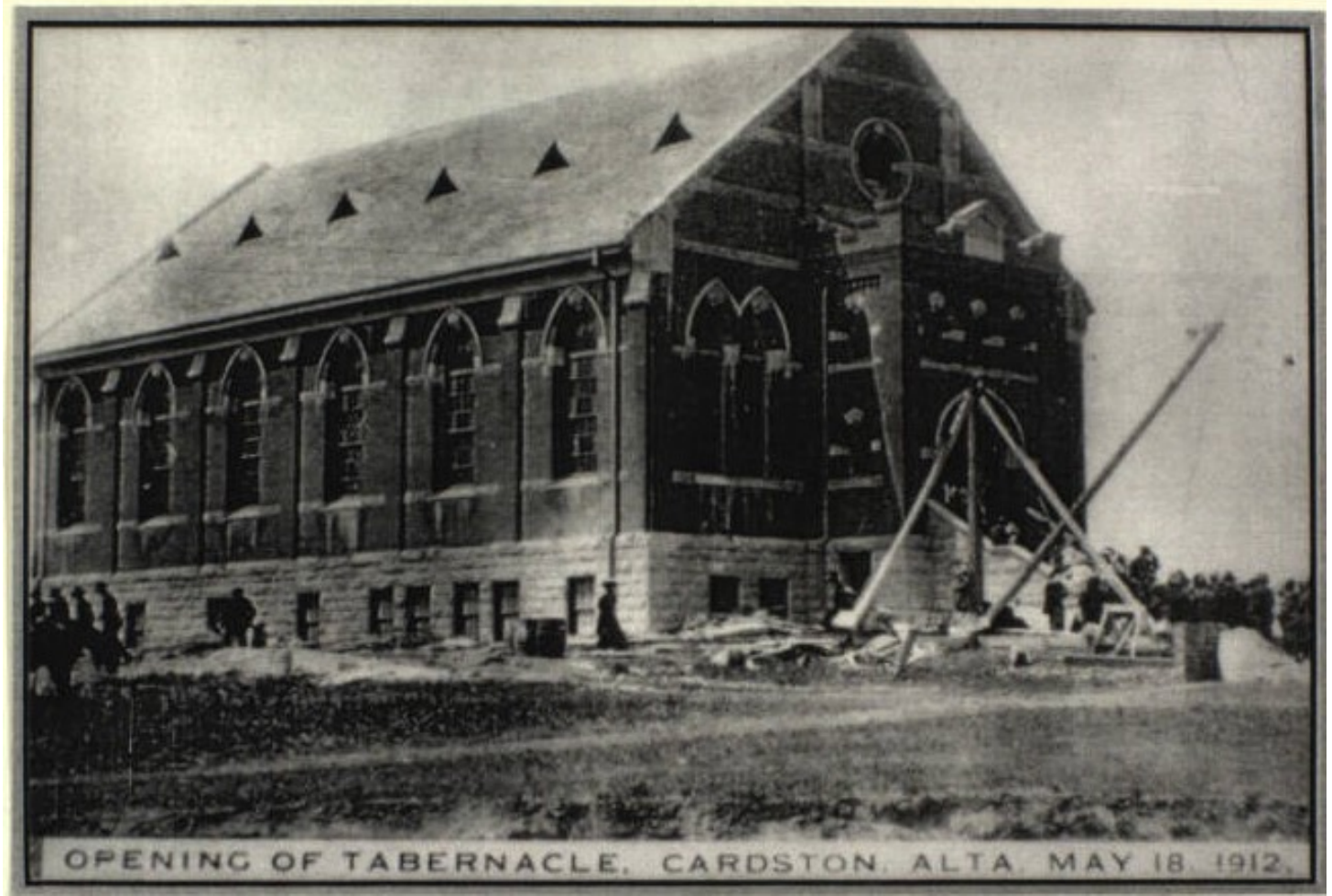

Figure 17: The Cardston Tabernacle, 1912. "Cardston Temple: An Historical Record,” University of Lethbridge Archive.

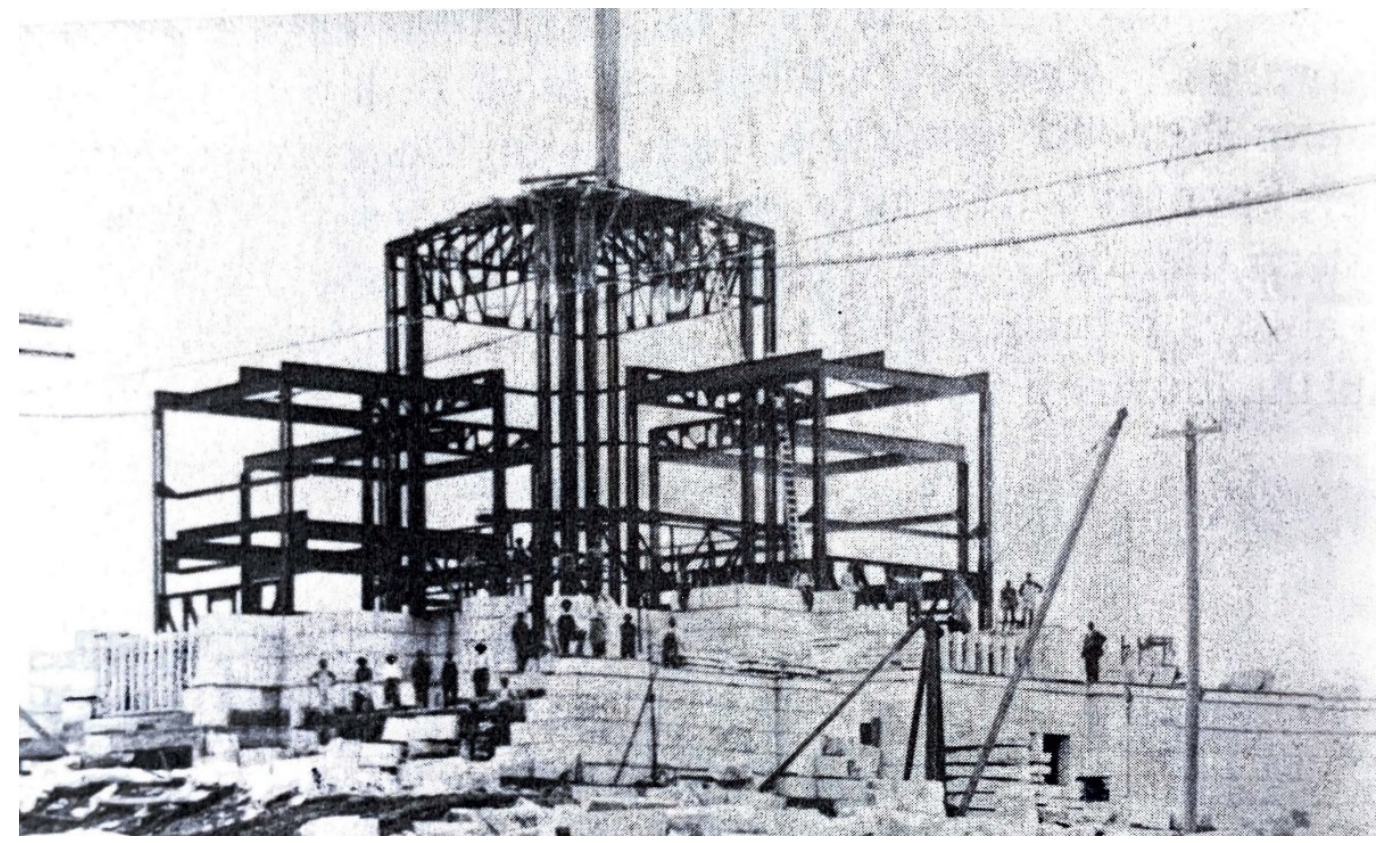

Figure 18: The Cardston Temple metal frame when the cornerstone was laid, Sept 19, 1913. Church History Library, P390. 


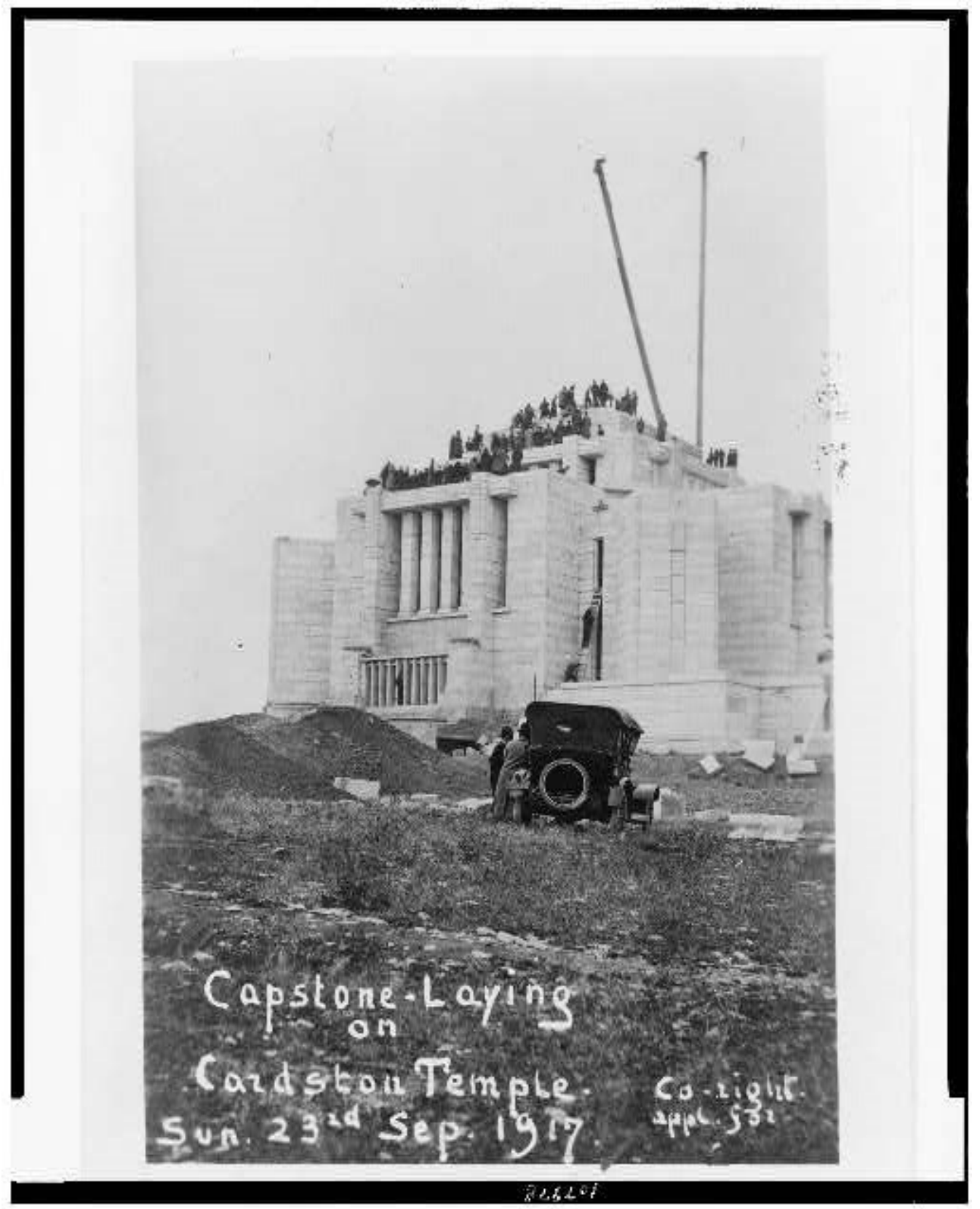

Figure 19: Capstone Laying, Sept 23, 1917. Library of Congress 93506506. 


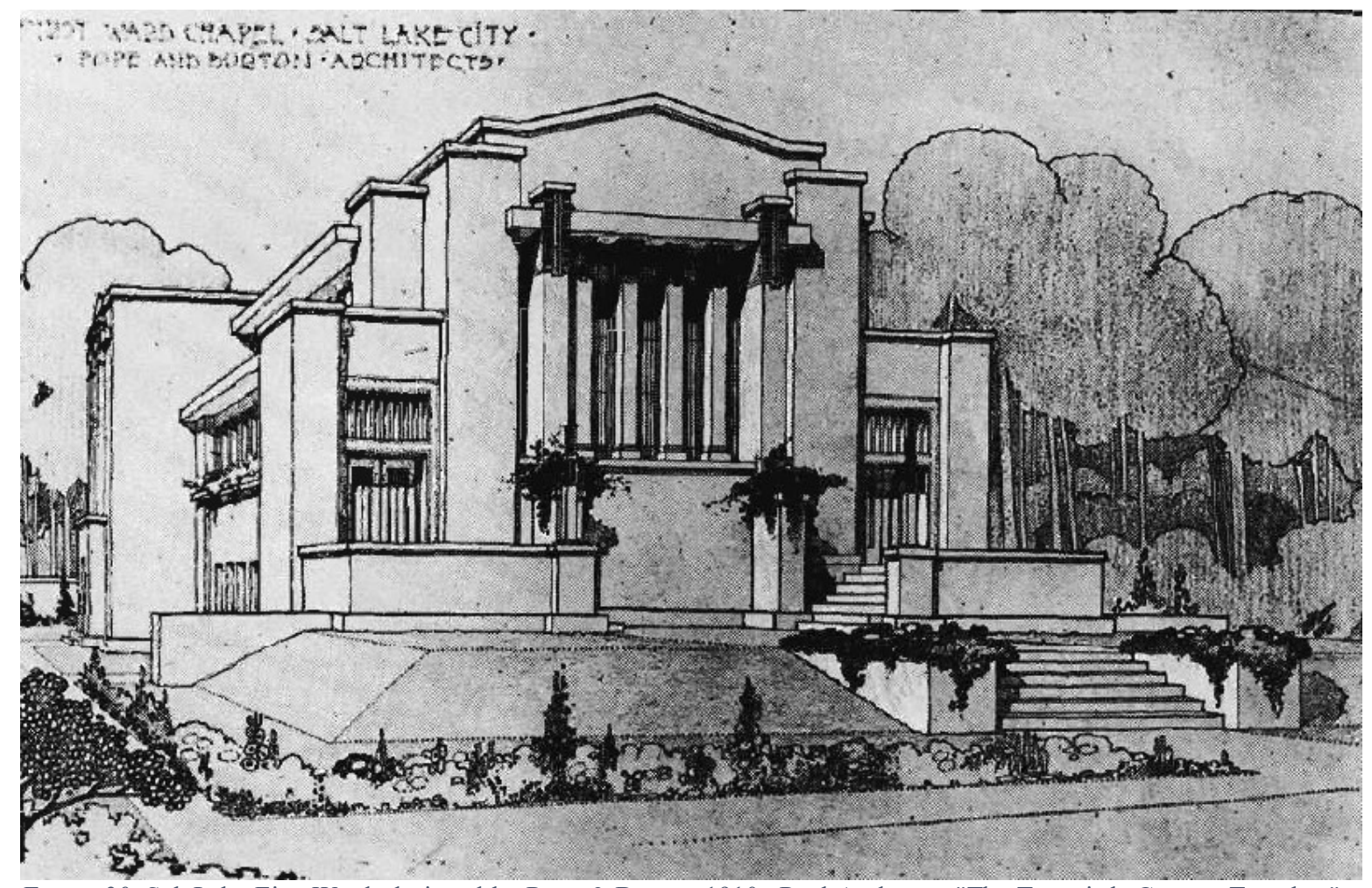

Figure 20: Salt Lake First Ward, designed by Pope \& Burton, 1910. Paul Anderson, "The Twentieth Century Temples."

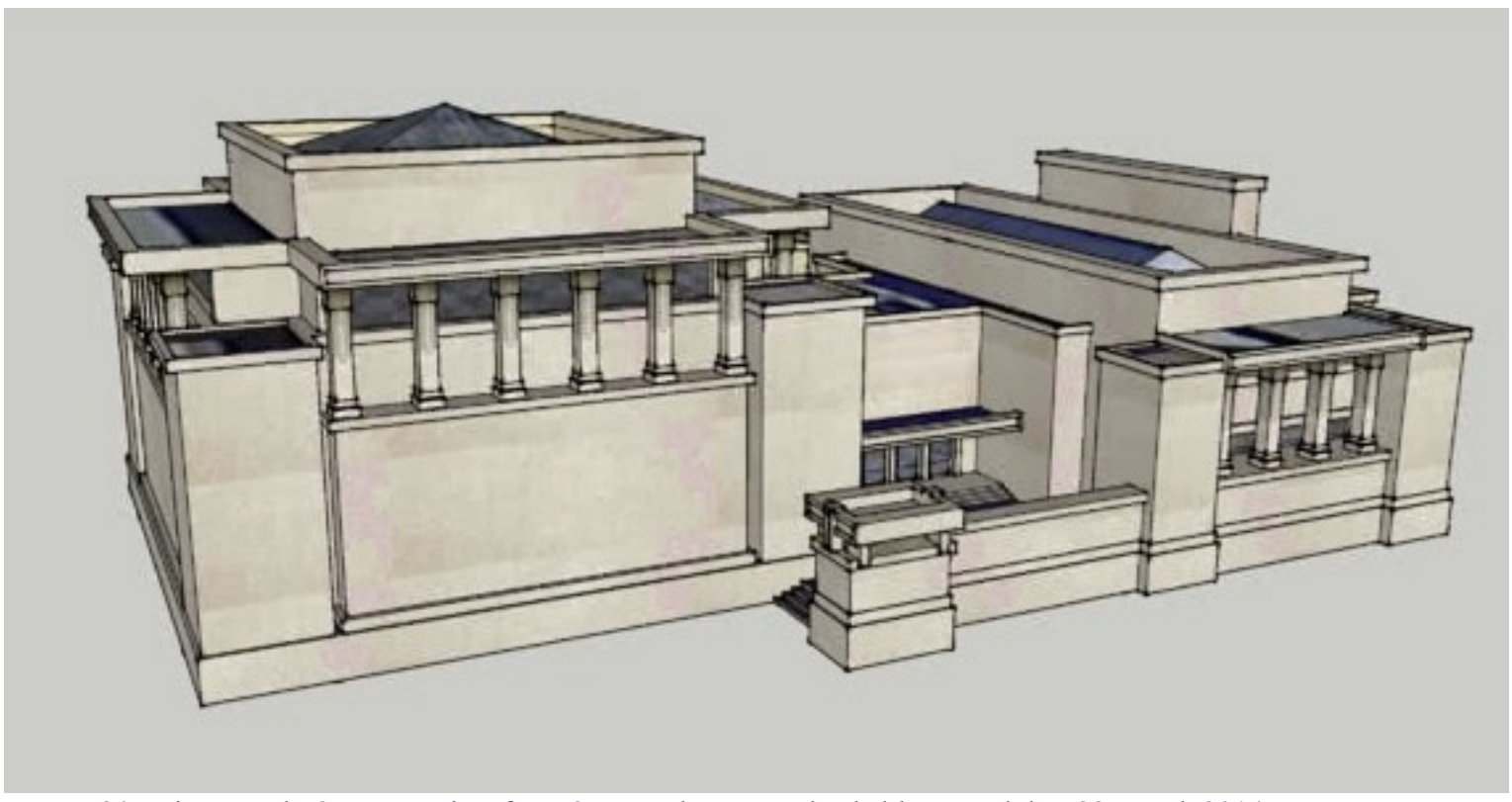

Figure 21 Unity Temple 3-D recreation from 3D Warehouse. Uploaded by user d.das, 22 March 2014.

Note that Unity Temple is the square structure on the left, with a meeting hall known as Unity House for social gatherings attached on the right by a loggia. 


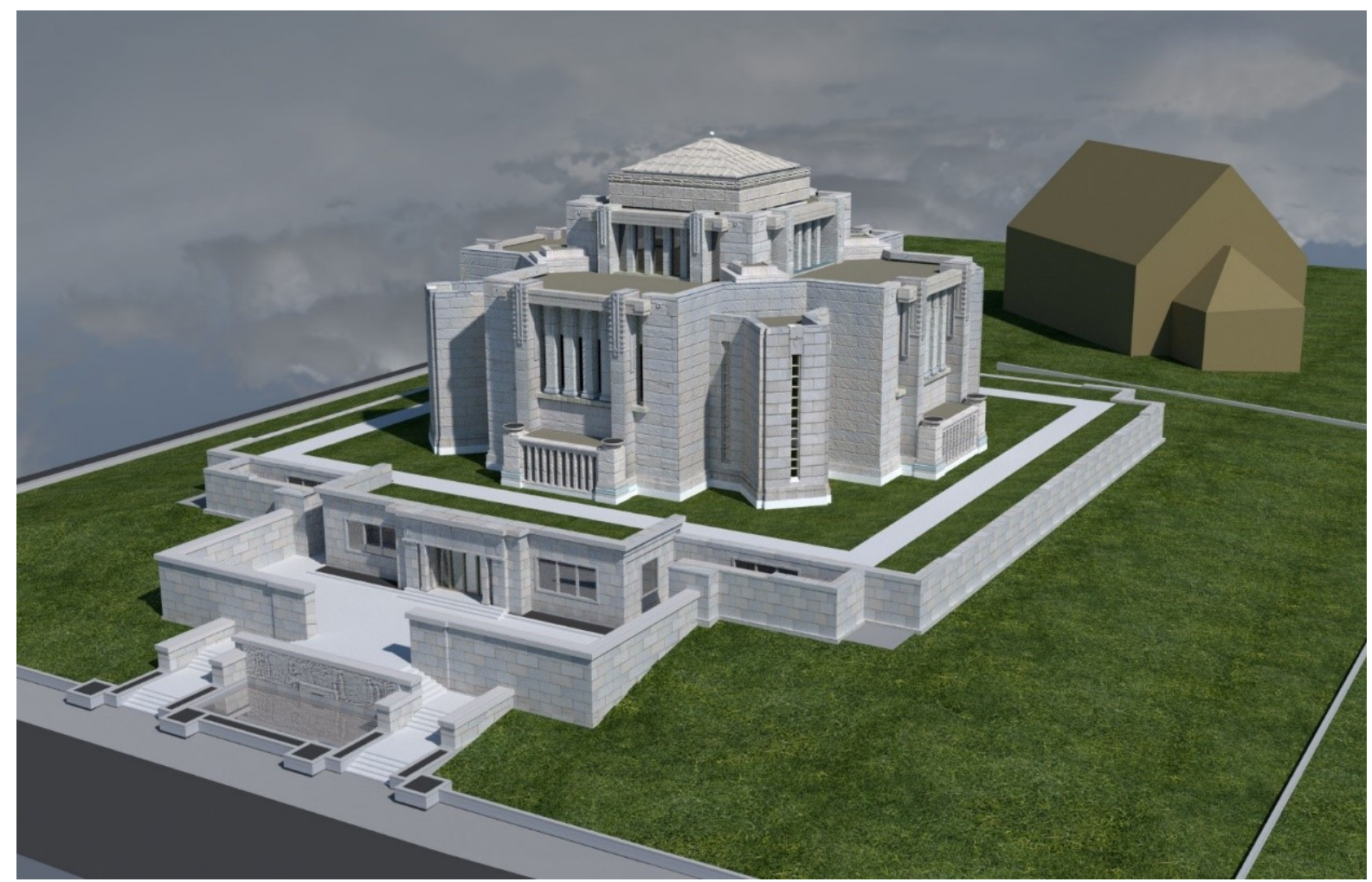

Figure 22: Cardston Temple in 1923. 3D reconstruction by Brian Olsen, 3dtemples.photogent.com.

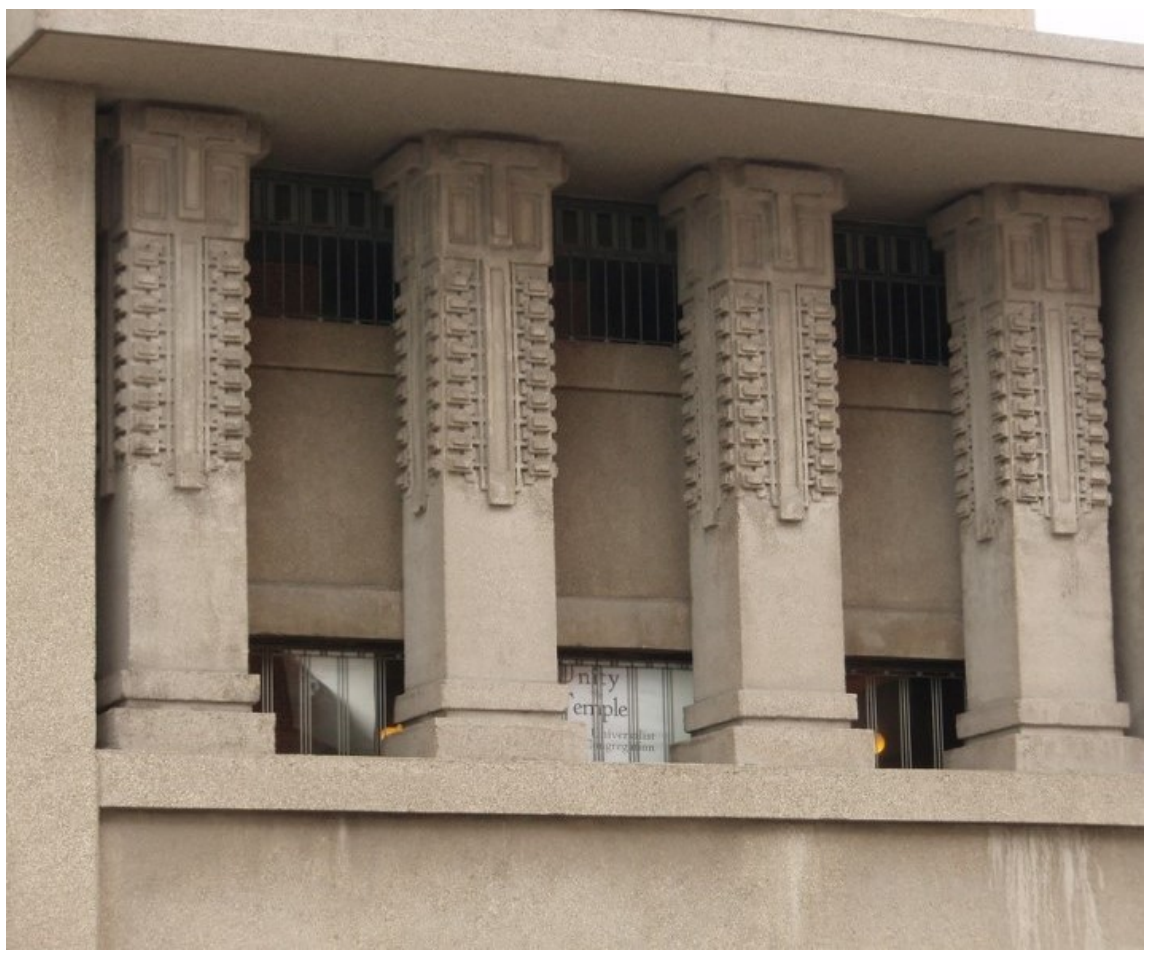

Figure 23: Unity Temple detail, “Unity Temple” webpage, Frank Lloyd Wright Sites. Photograph taken by Teresa Hsu. 


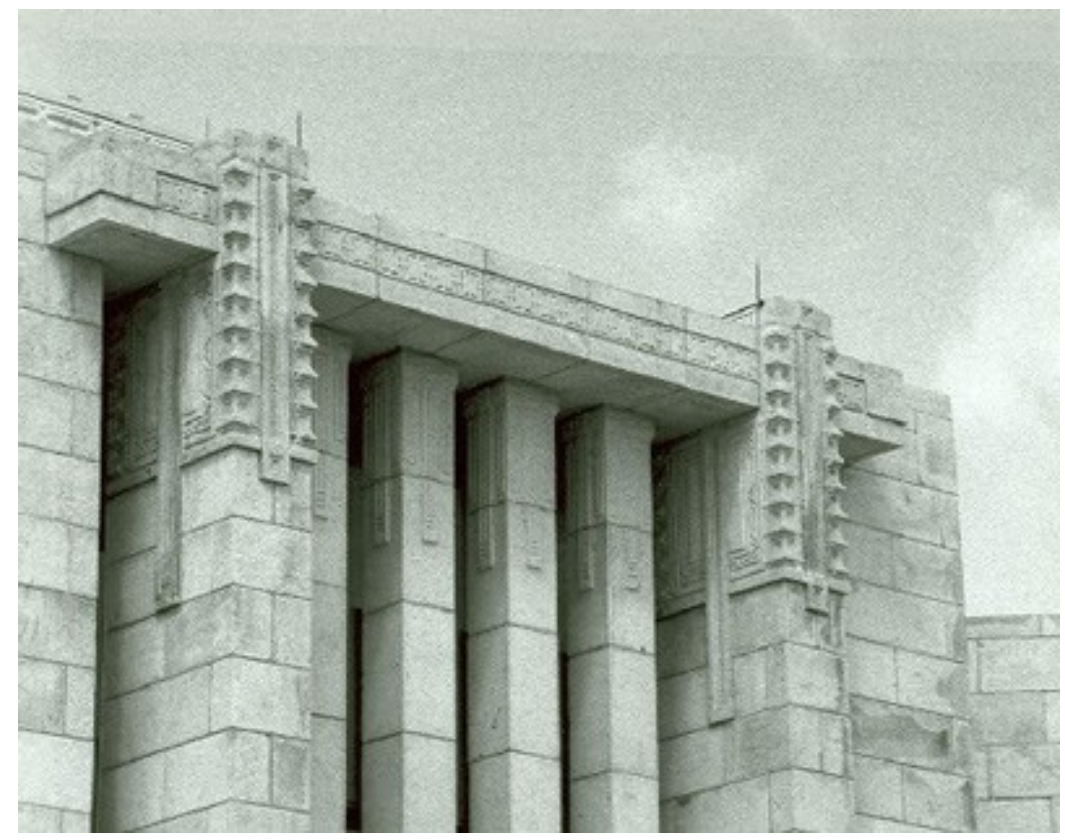

Figure 24: Cardston Temple detail. Parks Canada, 1992.

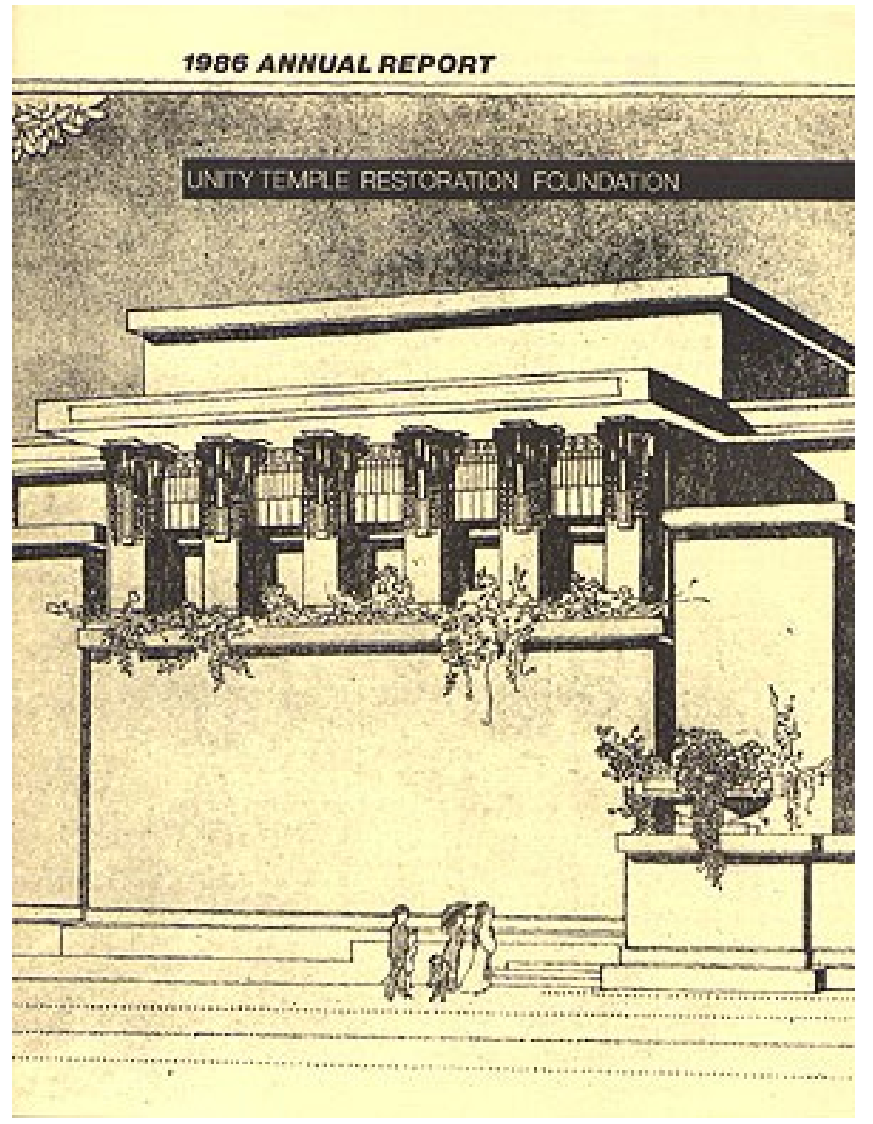

Figure 25: Unity Temple sketch. Unity Temple Restoration Foundation. 


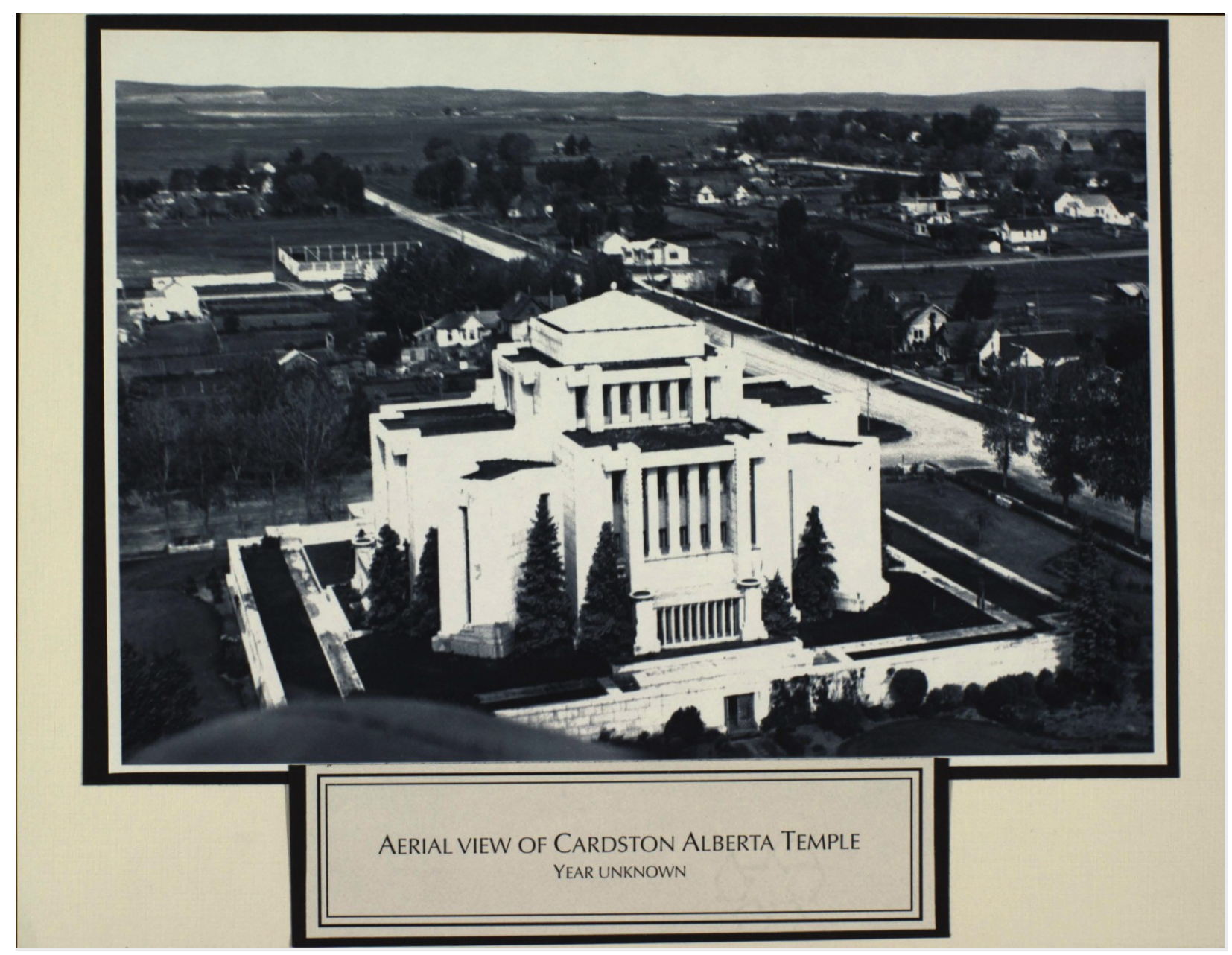

Figure 26: The Cardston Temple Aerial View, 1930s. Cardston Historical Society. 


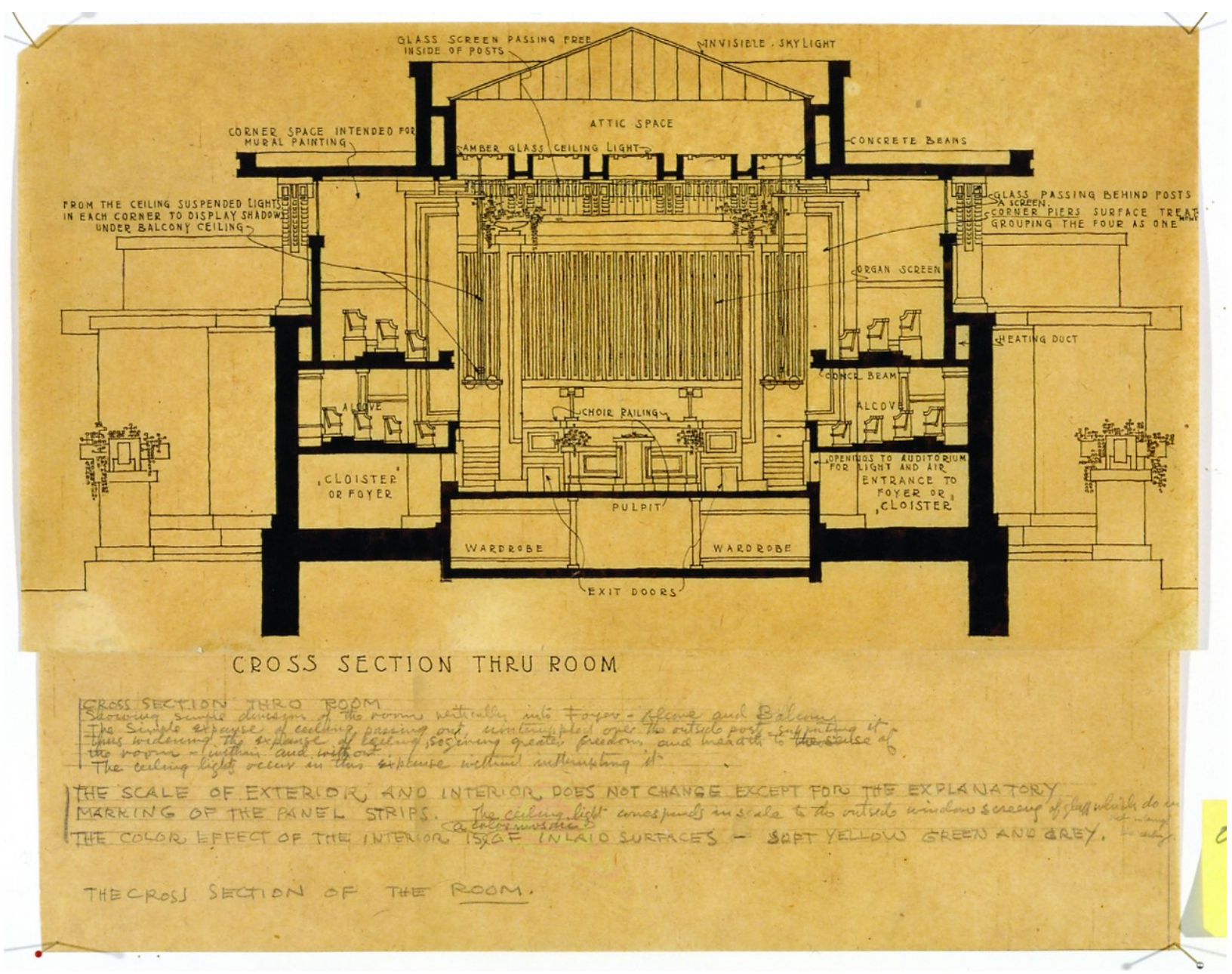

Figure 27: Unity Temple Cross Section. "Exhibit: Frank Lloyd Wright: Organic Architecture for the $21^{\text {st }}$ Century," Arch Daily. 
1 dressing rooms

2 sealing rooms

3 terrestrial room

4 mechanical

5 garden room

6 baptistry

7 mech, basement

1 reception/waiting

2 administration

3 chapel

4 baptistry

5 world room

6 celestial room

7 sealing rooms

8 creation room

9 children's area

10 tunnel to boiler plant

11 mech. basement

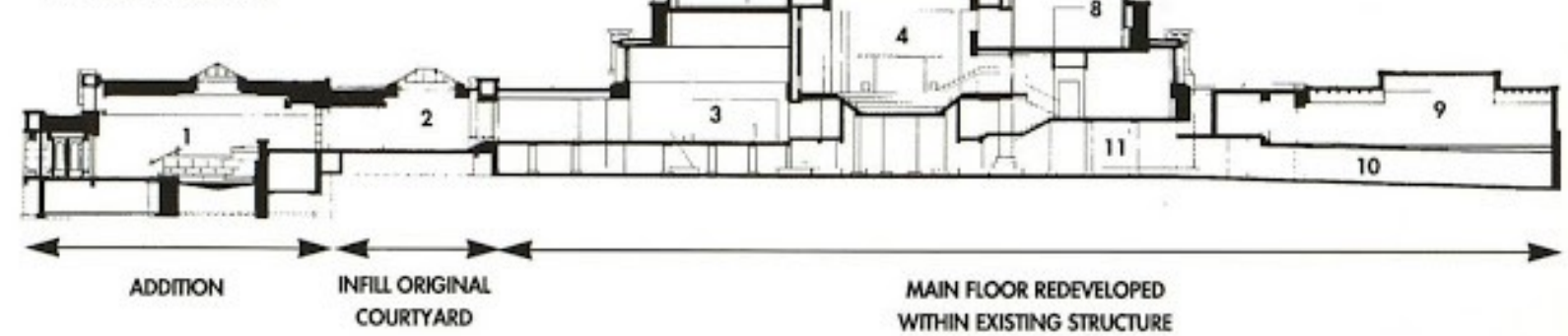

Figure 28: Cardston Temple Cross Section. "Alberta Temple, Cardston, Alta: Renovation/Restoration/Addition." The Canadian Architect (1991): 32. Article in the L. Tom Perry Special Collections at Brigham Young University. 


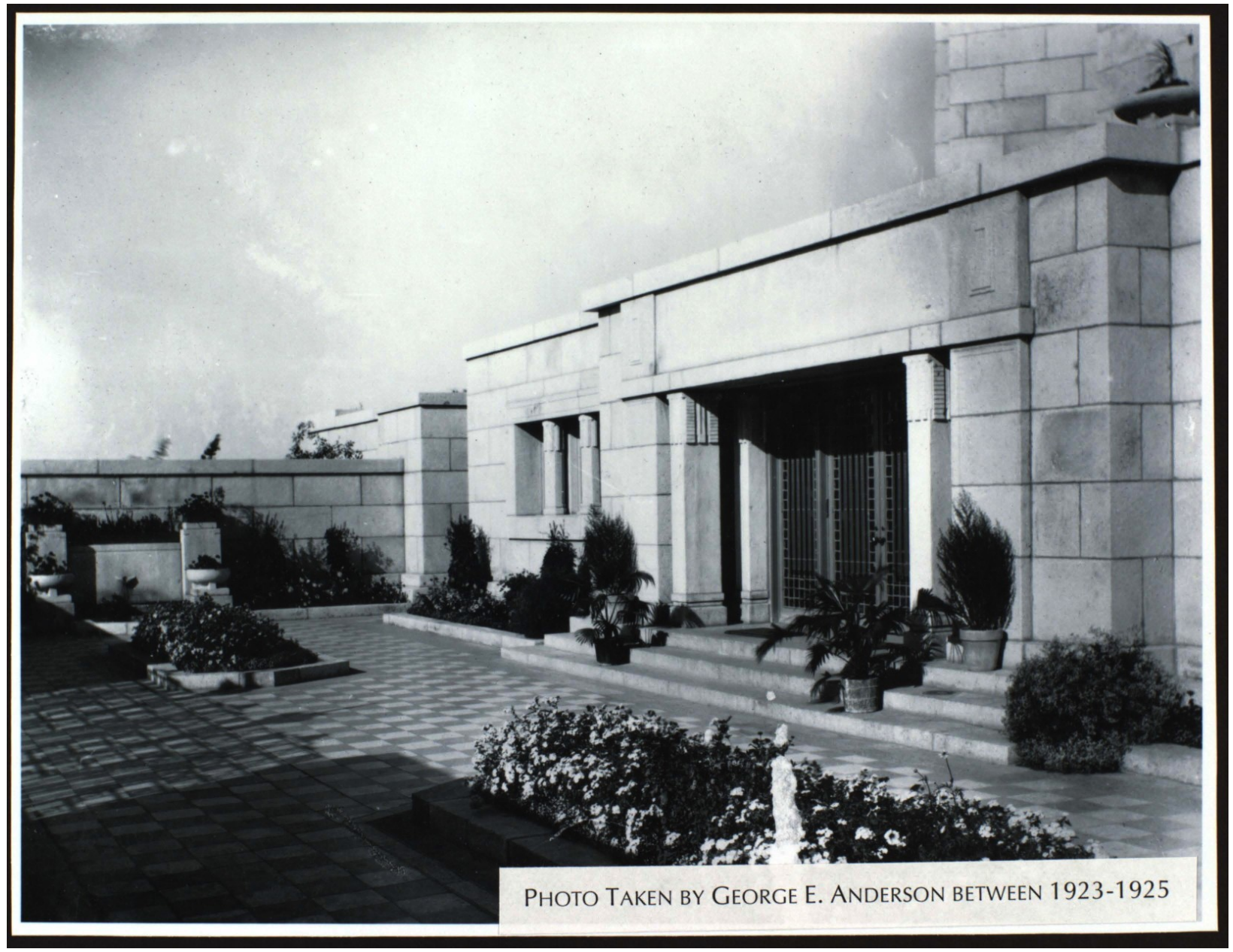

Figure 29: Courtyard of the temple, Cardston Historical Society Digital Archive, 8133 box 1 fd 5, no, 98. 


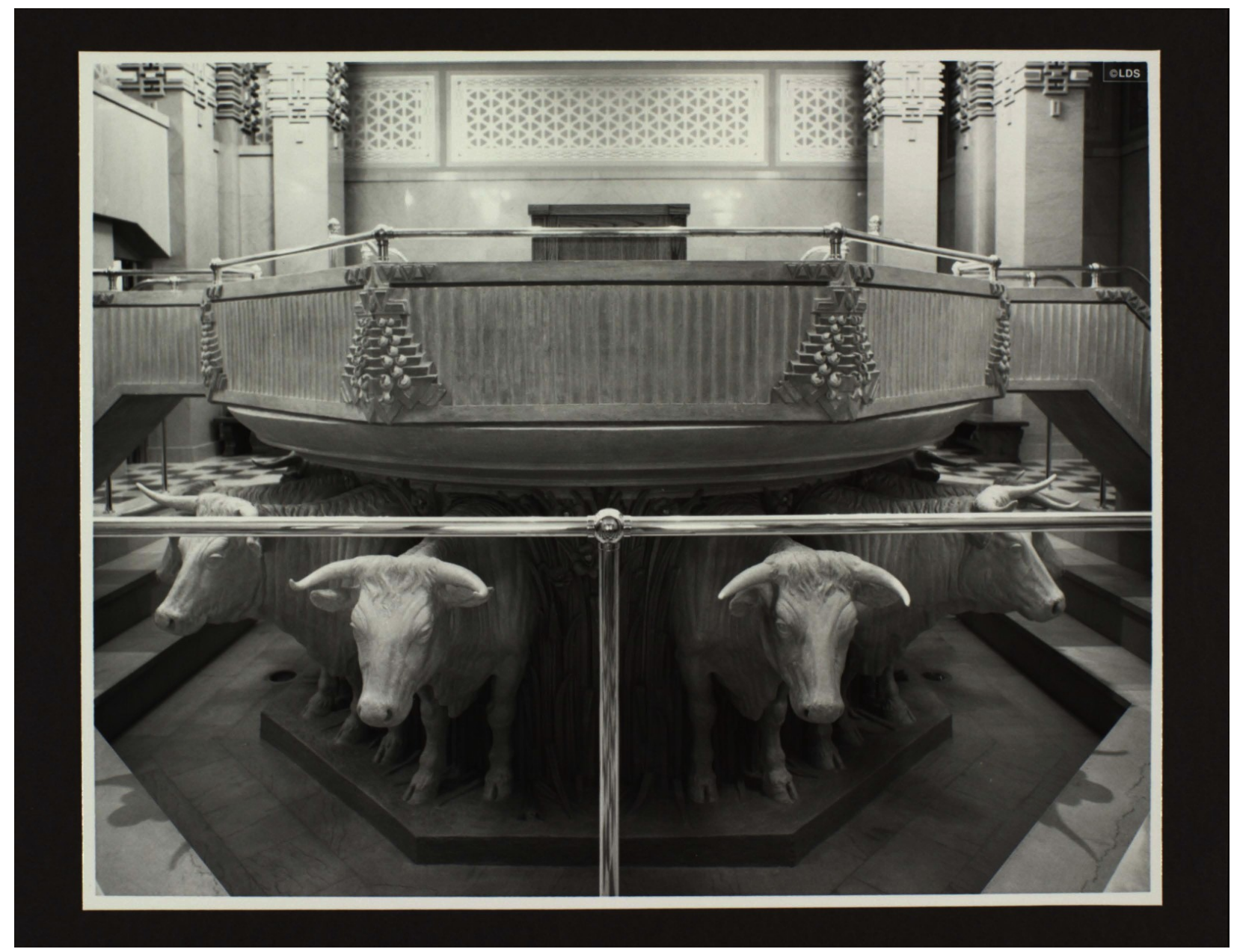

Figure 30: Cardston Temple baptismal font. Cardston Historical Society, PH 8133, Box 2, FD 11.

Notice the geometric pillars framing the clerestory screen reminiscent of Unity Temple's interior. 


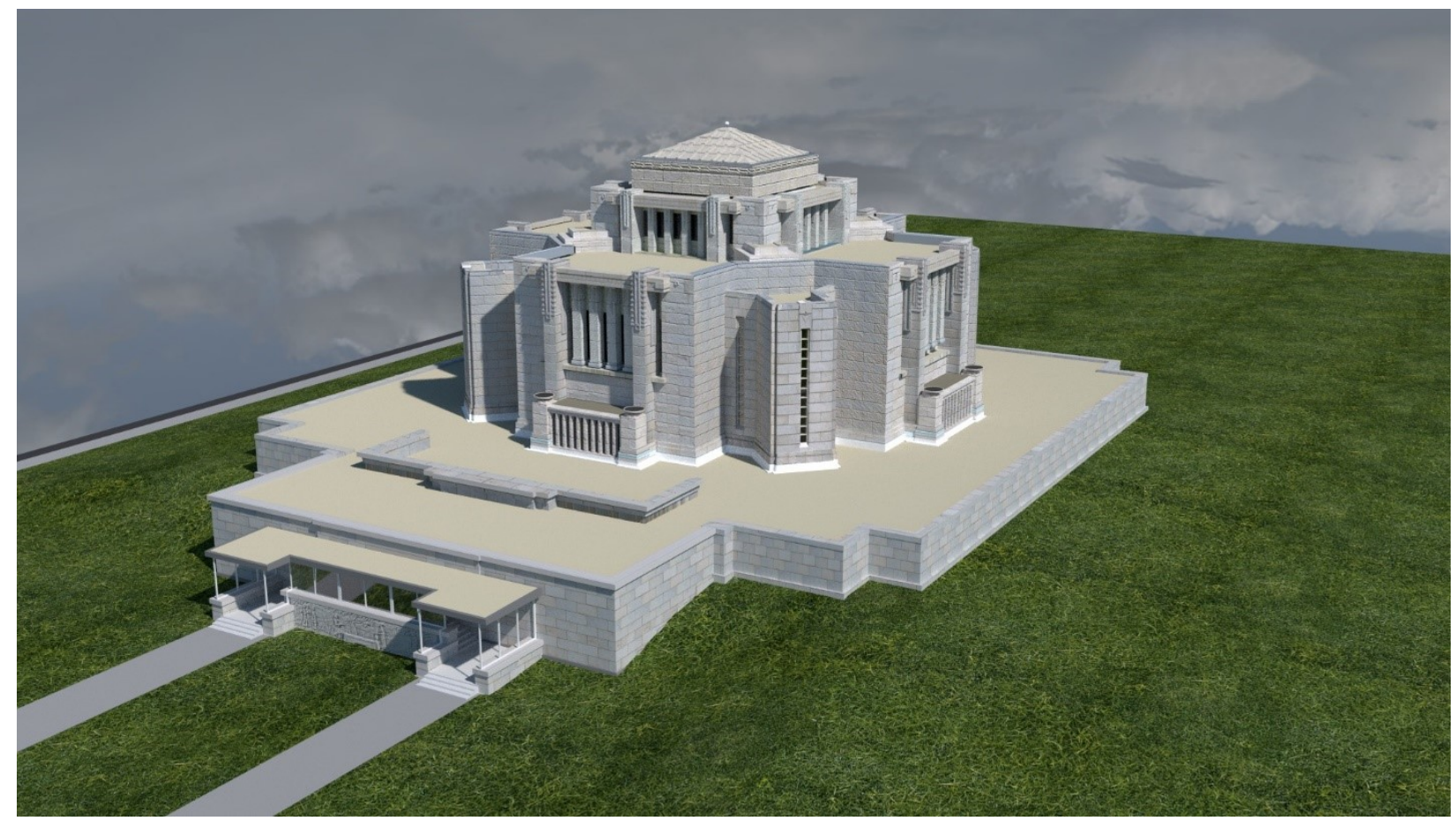

Figure 31: Cardston Temple after the 1960's renovation. 3D reconstruction by Brian Olson. 


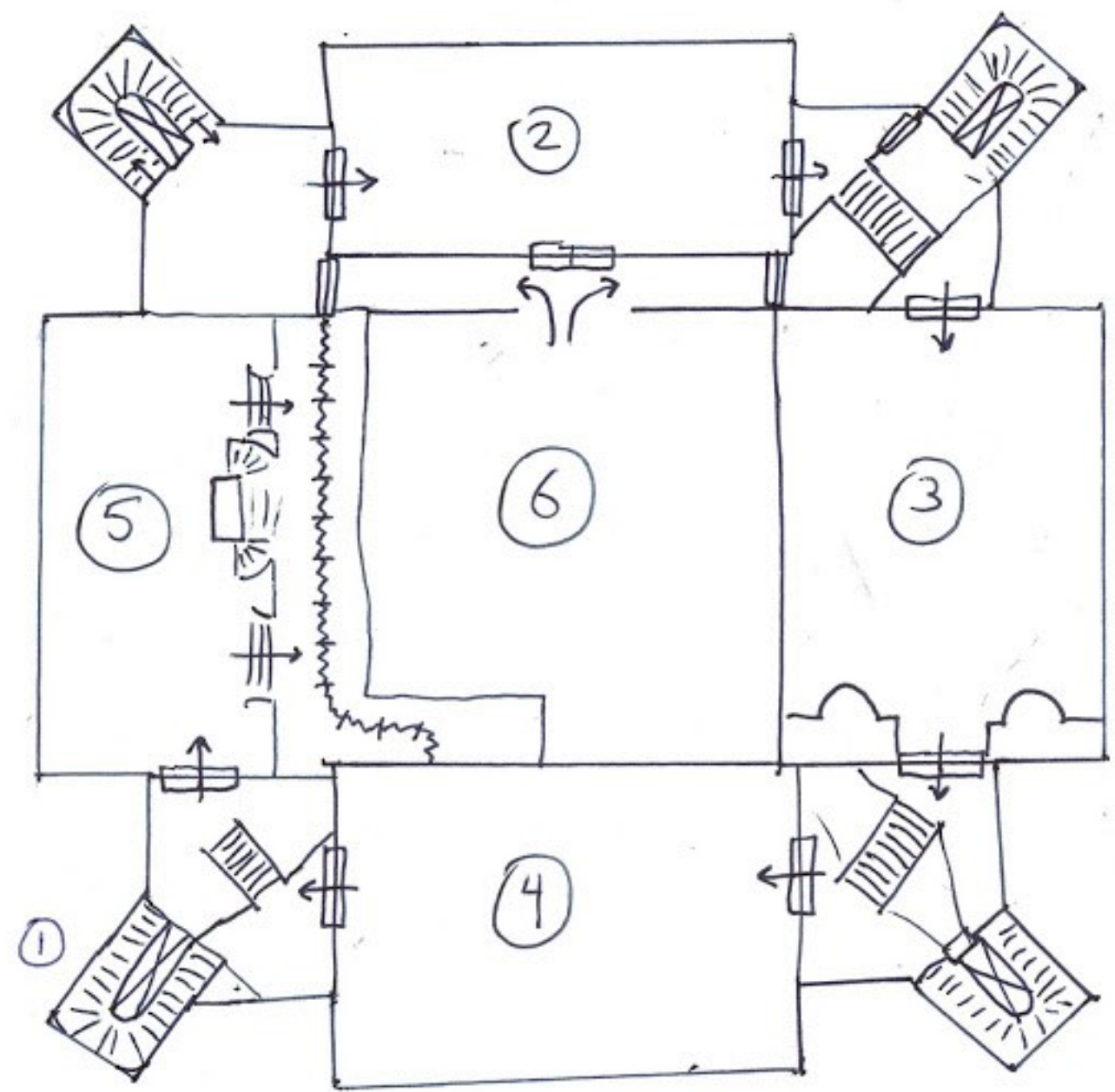

Figure 32: Modern drawing of the Cardston Temple plan, as no official plan is available. Image from LDS Pioneer Architecture blog, "Cardston Temple," 19 Aug 2018. The following guide to the image was original to the source:

"The Creation room is one full floor below the Celestial room. 1 - Staircase that patrons ascend to begin the session

2 - Creation Room (on middle floor); Sealing Rooms (on top floor)

3 - Garden Room

4 - World Room

5 - Terrestrial Room (on top floor); Sealing Rooms (on middle floor) 6 - Celestial Room" 


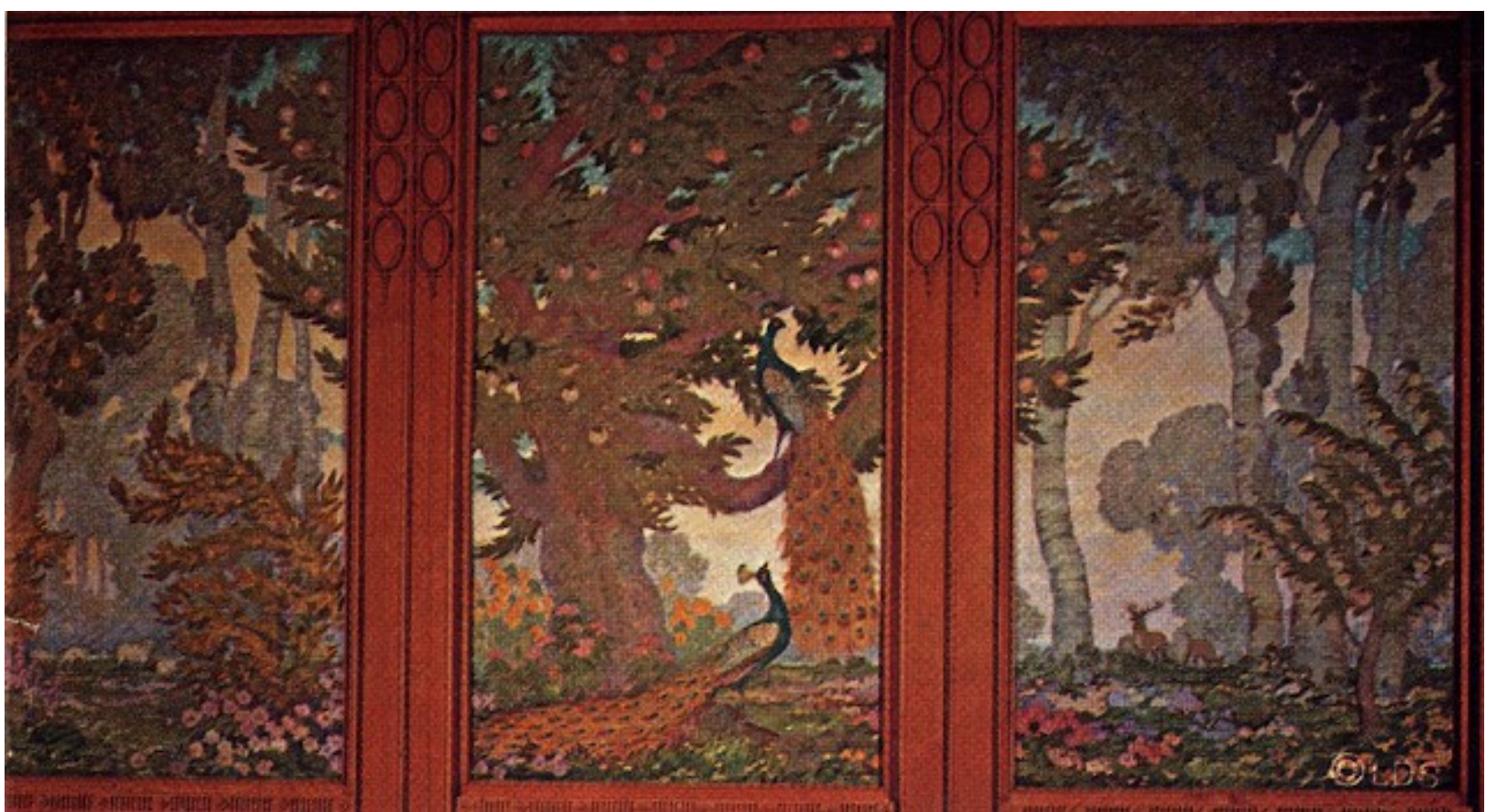

Figure 33: A section of the mural in the Cardston temple's Garden room, painted by Lee Greene Richards. Photo from LDS Pioneer Architecture, "Cardston Temple." 


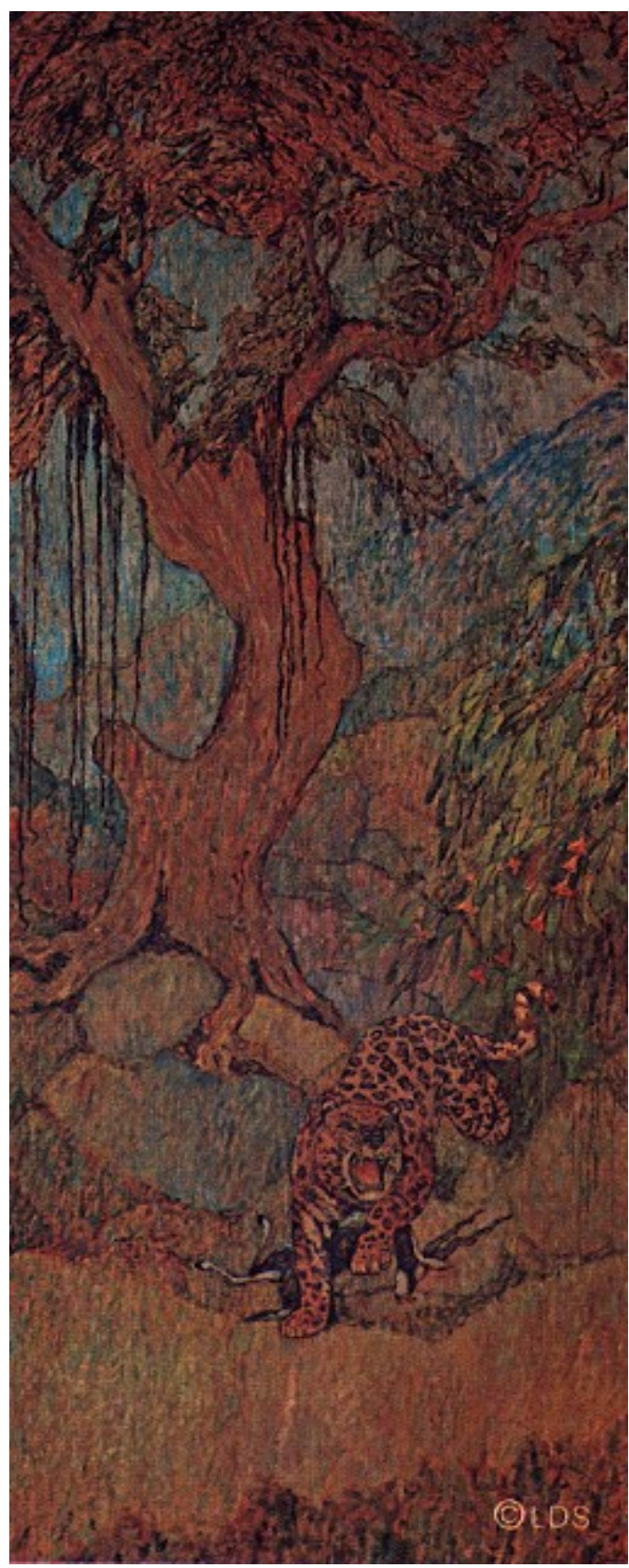

Figure 34: Section of the mural in the Cardston temple's World room, painted by Edwin Evans and Florence Christensen. Photo from LDS Pioneer Architecture, "Cardston Temple." 


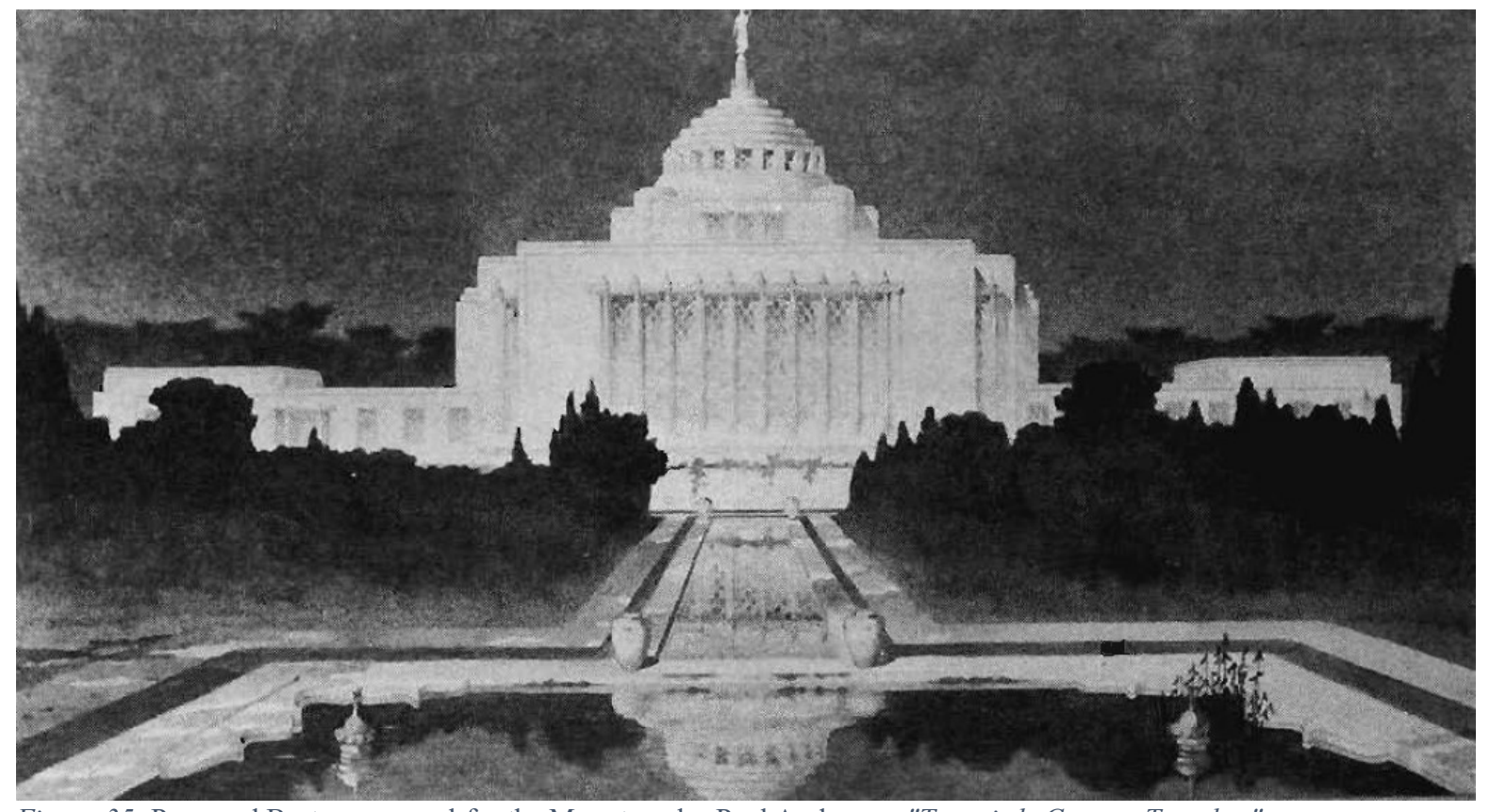

Figure 35: Pope and Burton proposal for the Mesa temple. Paul Anderson, "Twentieth Century Temples."

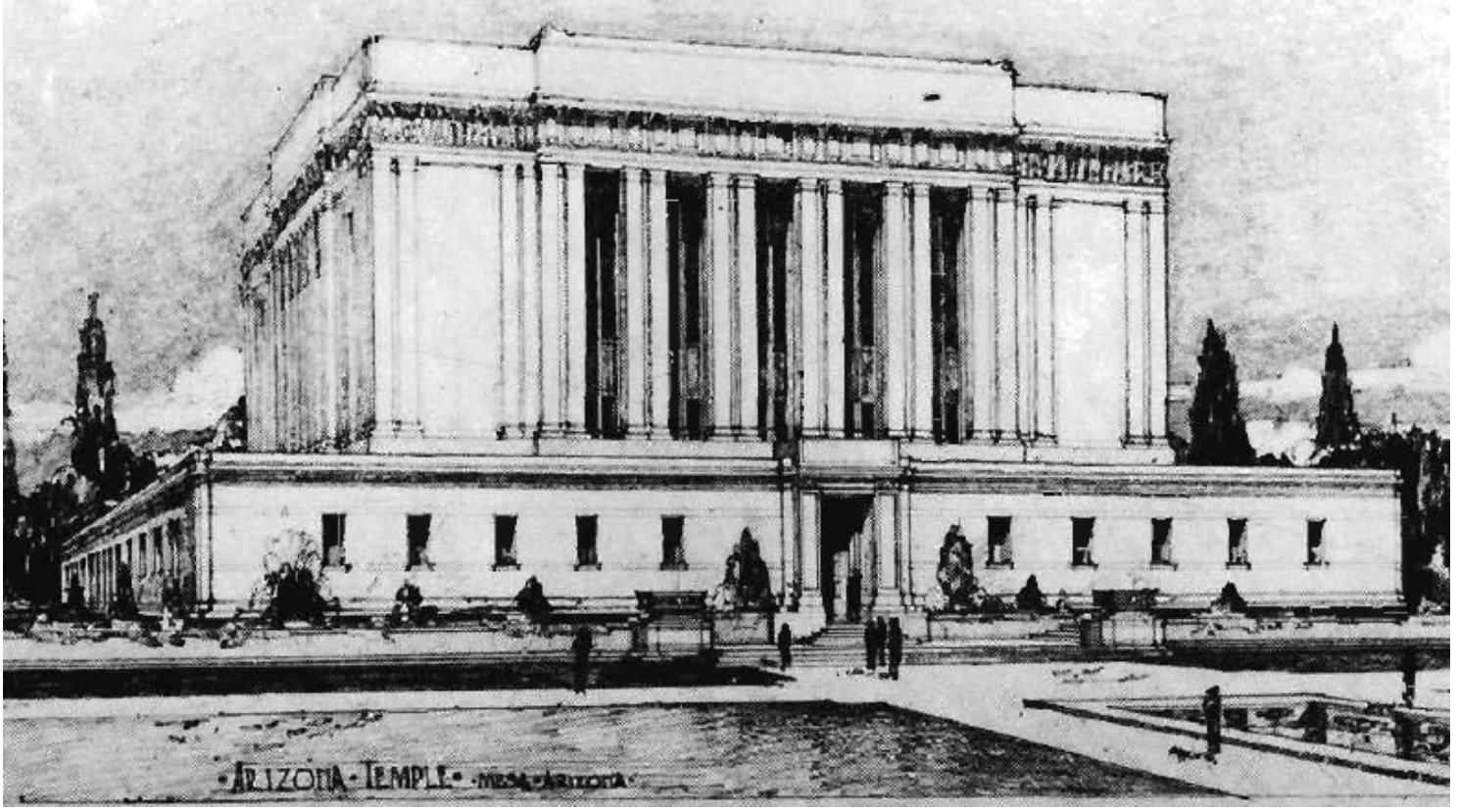

Figure 36: Young and Hansen winning design for the Mesa temple. Paul Anderson, "Twentieth Century Temples." 


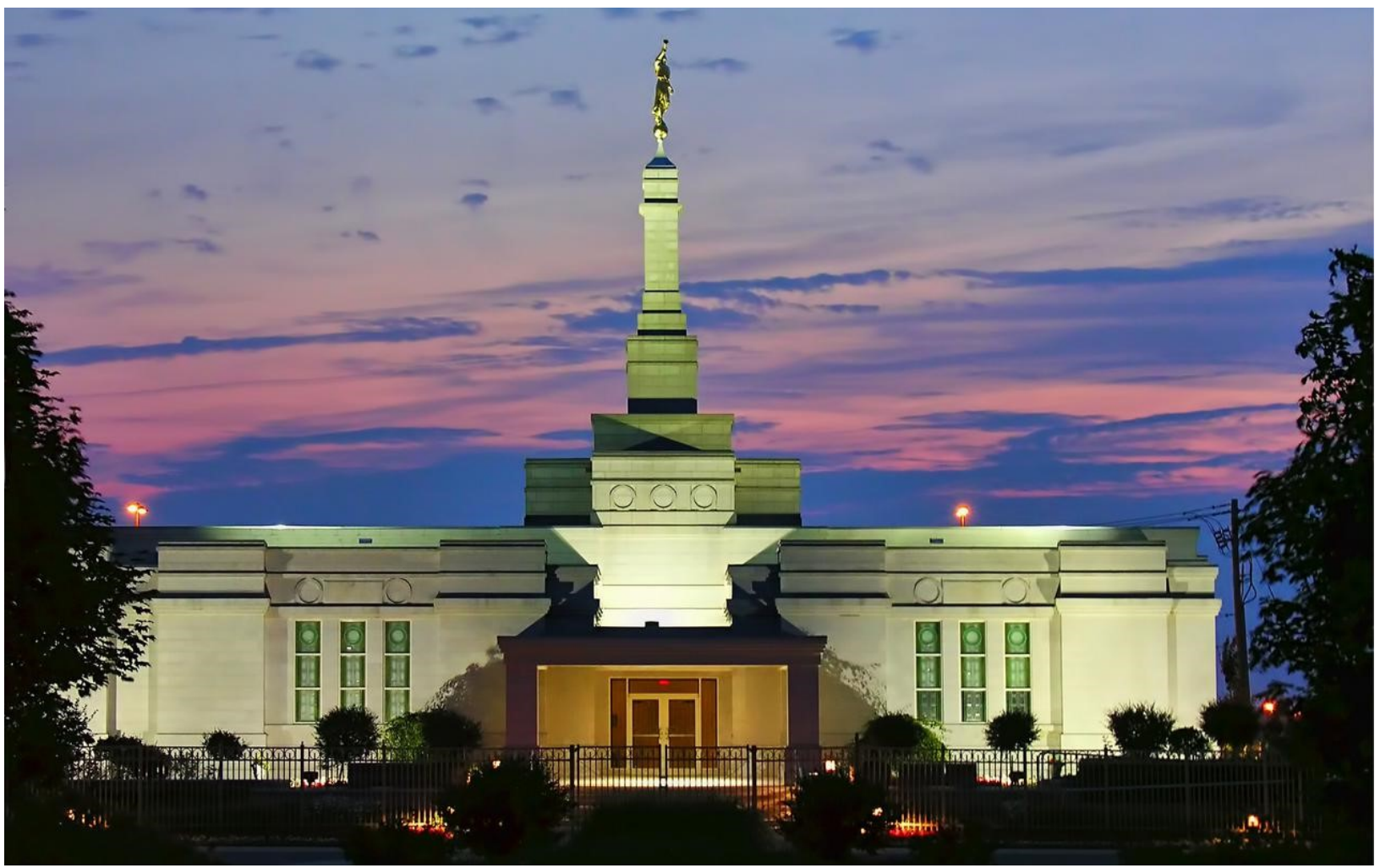

Figure 37: Montreal Temple. Image from The Church of Jesus Christ of Latter-day Saints.

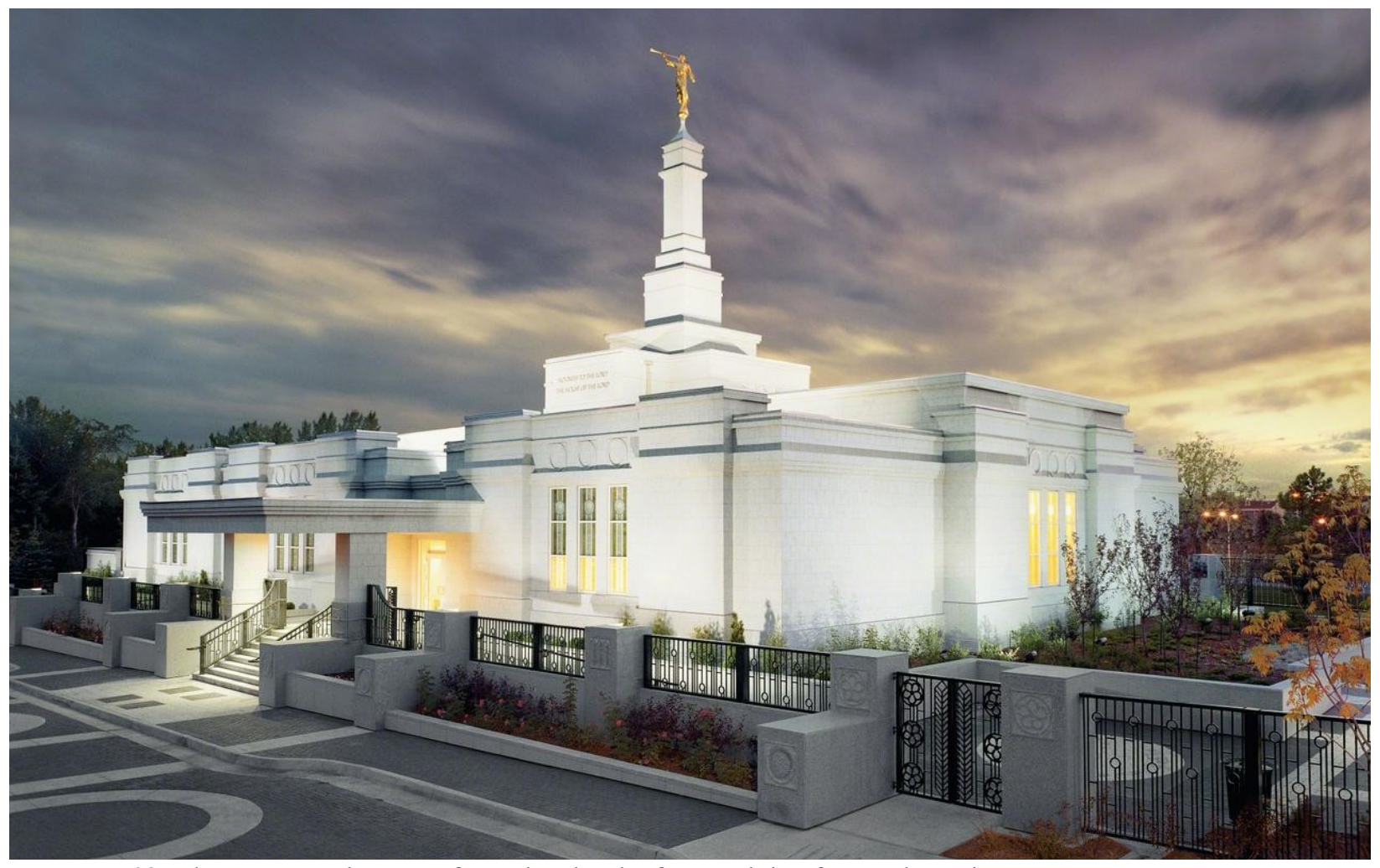

Figure 38: Edmonton Temple. Image from The Church of Jesus Christ of Latter-day Saints. 